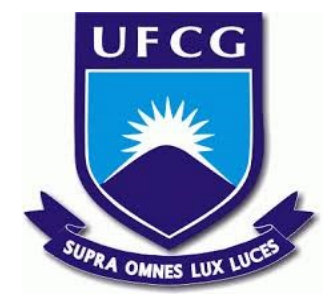

UNIVERSIDADE FEDERAL DE CAMPINA GRANDE

CENTRO DE DESENVOLVIMENTO SUSTENTÁVEL DO SEMIÁRIDO UNIDADE ACADÊMICA DE TECNOLOGIA DO DESENVOLVIMENTO PROGRAMA DE PÓS-GRADUAÇÃO EM GESTÃO E REGULAÇÃO DE RECURSOS HÍDRICOS

CARLA ISONEIDE ARAÚJO DA SILVA

PEQUENAS BARRAGENS DE ÁGUA: DEFINIÇÃO DO GRAU DE HIERARQUIZAÇÃO PARA FINS DE FISCALIZAÇÃO. 


\title{
PEQUENAS BARRAGENS DE ÁGUA: DEFINIÇÃO DO GRAU DE HIERARQUIZAÇÃO PARA FINS DE FISCALIZAÇÃO.
}

\begin{abstract}
Dissertação apresentada Programa de Pós-Graduação em Gestão e Regulação de Recursos Hídricos, no Centro de Desenvolvimento Sustentável do Semiárido da Universidade Federal de Campina Grande, como requisito parcial para obtenção do título de Mestra em Gestão e Regulação de Recursos Hídricos.

Área de Concentração: Instrumentos da Política de Recursos Hídricos.

Linha de Pesquisa: Ferramentas Aplicadas aos Instrumentos de Gestão de Recursos Hídricos.
\end{abstract}

Orientador: Professor Dr. John Elton de Brito Leite Cunha. 
S586p Silva, Carla Isoneide Araújo da

Pequenas barragens de água: definição do grau de hierarquização para fins de fiscalização. / Carla Isoneide Araújo da Silva. - Sumé PB: [s.n], 2021.

$92 \mathrm{f}$.

Orientador: Professor Dr. John Elton de Brito Leite Cunha.

Dissertação de Mestrado - Universidade Federal de Campina Grande; Centro de Desenvolvimento Sustentável do Semiárido; Mestrado Profissional em Rede Nacional em Gestão e Regulação de Recursos Hídricos - PROFÁGUA.

1. Barragens. 2. Pequenas barragens. 3. Reservatórios. 4. Recursos hídricos. 5. Software QGIS 3.10. 6. Google Earth Engine. 7. Método HSV. 8. Segurança de pequenas barragens. 9. Processamento de imagens. 10. Imagens de satélite. 11. Sensoriamento remoto. 12. Risco em barragens. 13. Normalized Difference Water Index. 14. Modified Normalized Difference Water Index. 15. Política Nacional de Segurança de Barragens - Brasil. 16. Índices espectrais. I. Cunha, John Elton de Brito Leite. II. Título. 


\title{
PEQUENAS BARRAGENS DE ÁGUA: DEFINIÇÃO DO GRAU DE HIERARQUIZAÇÃO PARA FINS DE FISCALIZAÇÃO.
}

\begin{abstract}
Dissertação apresentada Programa de Pós-Graduação em Gestão e Regulação de Recursos Hídricos, no Centro de Desenvolvimento Sustentável do Semiárido da Universidade Federal de Campina Grande, como requisito parcial para obtenção do título de Mestra em Gestão e Regulação de Recursos Hídricos.
\end{abstract}

BANCA EXAMINADORA:

Professor Dr. John Elton de Brito Leite Cunha Orientador - UAEP/CDSA/UFCG

Professor Dr. George do Nascimento Ribeiro.

Examinador I - UAEB/CDSA/UFCG

Professora Dra. Maria Leide Silva de Alencar. Examinador Interno - UATEC/CDSA/UFCG

Trabalho aprovado em: 22 de fevereiro de 2021. 
Aos meus pais, avós e irmãos Ao meu esposo e ao meu filho. Aos meu Professores.

Dedico 


\section{AGRADECIMENTOS}

A Deus, por sempre me dar forças nos momentos mais difíceis e me permitir sempre continuar na fé de dias melhores.

Ao meu esposo e meu filho por todo suporte, companheirismo e compreensão nos momentos de ausência.

Aos meus pais, pelo apoio e suporte na vida e nos estudos.

Ao meu orientador, professor John Elton de Brito Leite Cunha, por todo estímulo e incentivo nos momentos necessários e todo conhecimento compartilhado.

Ao professor Hugo Alcântara, que nunca mede esforços para incentivar e ajudar os alunos sempre que solicitamos seu apoio.

Aos professores do programa ProfÁgua que contribuíram de forma significativa na minha formação acadêmica.

À minha turma de mestrado, formada por pessoas de garra e que se dedicam aos seus objetivos.

À Leia Lobo, por todo apoio nessa jornada, me incentivando e me resgatando nos momentos difíceis.

Ao apoio para realização deste trabalho por meio da Coordenação de Aperfeiçoamento de Pessoal de Nível Superior - Brasil (CAPES) - Código de Financiamento 001.

Ao Programa de Pós-Graduação em Rede Nacional em Gestão e Regulação de Recursos Hídricos - ProfÁgua, em nível de Mestrado, na Categoria Profissional, Projeto CAPES/ANA AUXPE №. 2717/2015, pelo apoio técnico científico aportado até o momento.

À Universidade Federal de Campina Grande - UFCG e ao Centro de Desenvolvimento Sustentável do Semiárido - CDSA pelo apoio técnico 
"A tarefa não é tanto ver aquilo que ninguém viu, mas pensar o que ninguém ainda pensou sobre aquilo que todo mundo vê."

Arthur Schopenhauer. 


\section{RESUMO}

Dados precisos sobre a distribuição e características de pequenas barragens são importantes para fins de gestão de emergências e planejamento de recursos hídricos em bacia hidrográfica e para auxiliar o monitoramento de indicadores do Objetivo de Desenvolvimento Sustentável (ODS) 6, sobre o uso e disponibilidade dos recursos hídricos e a implementação da gestão integrada dos recursos hídricos em todos os níveis. É necessário, assim, um sistema simplificado que auxilie no processo de identificação e classificação dessas pequenas barragens. Nesse contexto, a proposta deste estudo é identificar a presença de pequenos reservatórios através de imagens do MSI/Sentinel-2 entre janeiro e dezembro de 2020 e elaborar um Grau de Hierarquização (GR) para ações de fiscalização dos órgãos gestores. Foram utilizados para identificação o Normalized Difference Water Index (NDWI), Modified Normalized Difference Water Index e o método de transformação de espaço de cores RGB para HSV. O software QGIS versão 3.10 e o Google Earth Engine foram utilizados para o processamento das imagens e composição dos mapas apresentados. Os resultados comprovaram que o método HSV apresentou melhor resultado na identificação dos alvos propostos. A partir da aplicação do GR a uma pequena barragem de água, foi possível avaliar o seu nível de risco potencial e propor uma escala de prioridade para ações de fiscalização. Por fim, pode-se concluir que o GR pode auxiliar na tomada de decisão, fornecendo aos órgãos públicos uma ferramenta de fácil utilização para avaliar a prioridade de ação em pequenos barramentos.

Palavras-chave: Pequenos reservatórios. Índices Espectrais. Sensoriamento Remoto. Política Nacional de Segurança de Barragens. 


\begin{abstract}
Accurate data on the distribution and characteristics of small dams are important for the purposes of emergency management and planning of water resources in the river basin and for monitoring indicators of the Sustainable Development Goals (SDG) 6, on the use and availability of water resources and implementation of integrated water resources management at all levels. It is necessary, therefore, a simplified system that helps in the process of identification and classification of these small dams. In this context, the purpose of this study is to identify the presence of small reservoirs through images from MSI / Sentinel-2 between January and December 2020 and to elaborate a Degree of Hierarchization (DH) for inspection actions by the management bodies. The Normalized Water Difference Index (NDWI), Modified Normalized Water Difference index and the space transformation colors method from RGB to HSV were used for identification. QGIS software version 3.10 and Google Earth Engine were used for image processing and composition of base maps. The results proved that the HSV method presented better result in the identification of the proposed targets. From the application of the $\mathrm{DH}$ to a small water dam, it was possible to assess the level of potential risk of the dam and propose a priority scale for inspection actions. Finally, it can be gained that the $\mathrm{DH}$ can assist in decision making, providing public agencies with a tool to use to assess the priority of action on small buses.
\end{abstract}

Keywords: Small dams. Dam Safety. Oversight. Remote sensing. National Dam Safety Politics. 


\section{LISTA DE FIGURAS}

Figura 1 - Completude das informações das barragens cadastradas no SNISB..........19

Figura 2 - Altura das barragens cadastradas no SNISB submetidas à PNSB ..............20

Figura 3 - Volume das barragens cadastradas no SNISB submetidas à PNSB ...........20

Figura 4 - Tipo de material construtivo das barragens cadastradas no SNISB

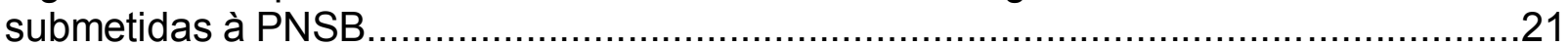

Figura 5 - Uso principal das barragens cadastradas no SNISB submetidas à PNSB....21

Figura 6 - Entidades fiscalizadoras de segurança de barragens .............................27

Figura 7 - Etapas para elaboração do IPRB proposta por Zuffo (2010) .......................39

Figura 8 - Fluxo metodológico proposto......................................................44

Figura 9 - Mapa de localização de Sumé........................................................45

Figura 10 - Regime pluviométrico do município de Sumé - Ano 2020.........................47

Figura 11 - Distribuição espacial das massas de água e barragens cadastradas no SNISB para o estado da Paraíba........................................................................

Figura 12 - Quantidade de barragens cadastradas no SNISB e massas de água

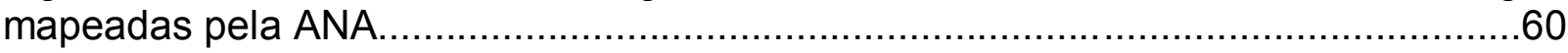

Figura 13 - Usos prioritários das barragens no estado da Paraíba............................60

Figura 14 - Distribuição espacial das massas de água e barragens cadastradas no SNISB para o município de Sumé.

Figura 15 - Resultado da composição das imagens RGB e HVS. (a) Composição RGB; (b) Composição HSV.

Figura 16 - Imagem ampliada das composições coloridas do município de Sumé. (a) Reservatório com 12.006 hectares no HSV; (b) Reservatório com 12.006 hectares no RGB; Reservatório com 10.484 hectares no HSV; (b) Reservatório com 10.484 hectares no RGB

Figura 17 - Massas d'água extraídas do GEE

Figura 18 - Imagens antes e depois do processo de classificação, quanto à área e a interseção das superfícies dos espelhos d'água com a rede de drenagem.

Figura 19 - Resultados da extração das massas d'água. (a) Composição RGB; (b) Resultado extraído da composição HSV, sobreposto a imagem RGB; (c) Resultado NDWI, sobreposto a imagem RGB e (d) Resultado NDWIm, sobreposto a imagem RGB.

Figura 20 - Comparação entre os índices propostos e a base de dados da ANA (2020)

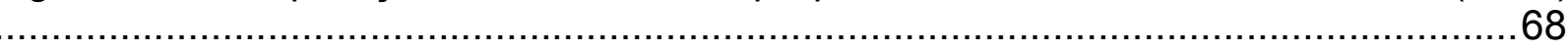

Figura 21 - Barragem de interesse e bacia de contribuição..................................71

Figura 22 - Perfil temporal da presença de água na barragem analisada ....................72

Figura 23 - Área de interesse a jusante da barragem........................................ 74 


\section{LISTA DE TABELAS}

Tabela 1 - Critério gerais para classificação quanto à $C R$ segundo a Resolução $n^{\circ}$

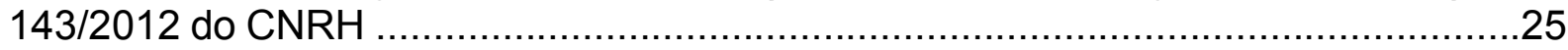

Tabela 2 - Classificação quanto ao volume hidráulico e à superfície hidrográfica.......29

Tabela 3 - Características das bandas espectrais do Sentinel-2 ...............................36

Tabela 4 - Precipitação anual acumulada para o município de Sumé de 2015 a 2020

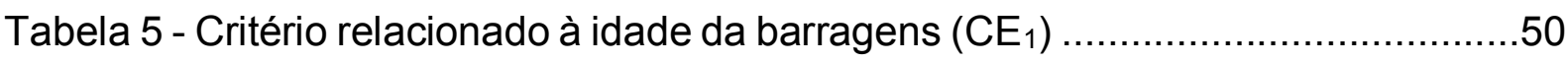

Tabela 6 - Escala dos dados fornecidos pela coleção Monthly Water History..............51

Tabela 7 - Classificação da existência de barramentos a montante da barragem $\left(\mathrm{CE}_{2}\right)$

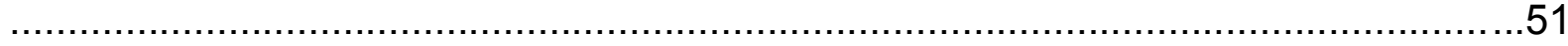

Tabela 8 - Classificação de acordo com o volume do reservatório $\left(\mathrm{CE}_{3}\right)$ ….................53

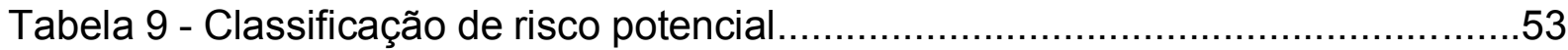

Tabela 10 - Classificação do indicador demográfico................................................55

Tabela 11 - Classificação do indicador econômico.................................................56

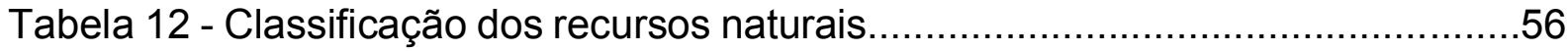

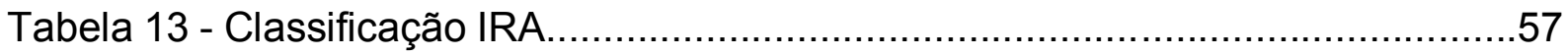

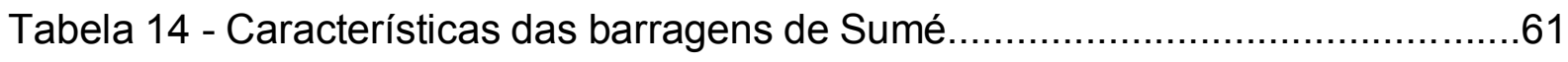

Tabela 15 - Quantitativo de massas d'água identificadas.........................................65

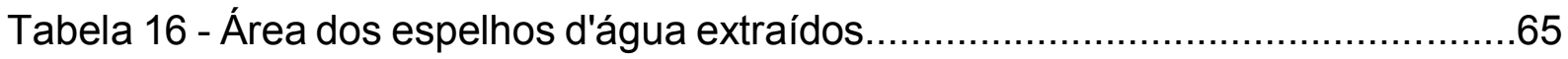

Tabela 17 - Resultado das métricas RMSE e MAE...................................................

Tabela 18 - Resultados dos critérios estruturais analisados....................................73

Tabela 19 - Resultados dos critérios para caracterização do vale a jusante.................76 


\section{LISTA DE QUADROS}

Quadro 1 - Periodicidade mínima dos ciclos de inspeções.....................................30

Quadro 2 - Acidentes ocorridos com barragens entre os anos 2018/2019................34

Quadro 3 - Critérios e subcritérios para avaliação do IPRB ...................................40

Quadro 4 - Critérios utilizados para cálculo do ISPB proposto por Pinto (2020) ..........42

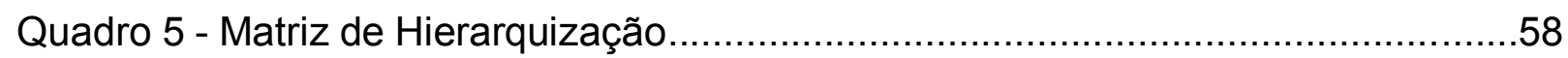

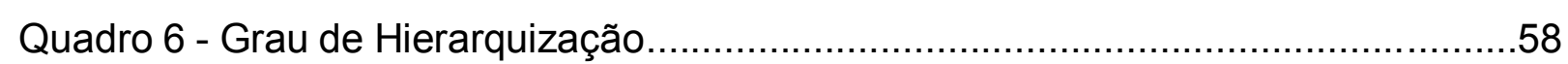

Quadro 7 - Resultado da Matriz de Hierarquização............................................77 


\section{SUMÁRIO}

1 INTRODUÇÃO

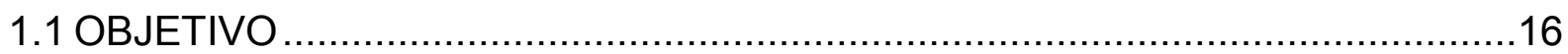

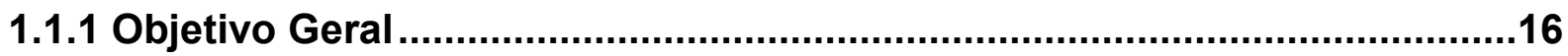

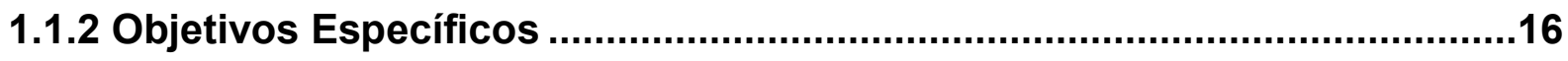

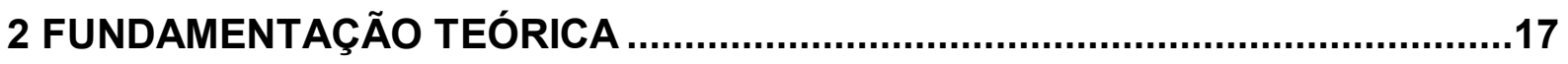

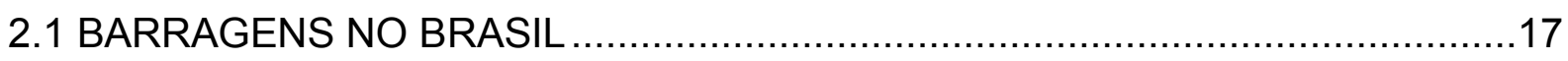

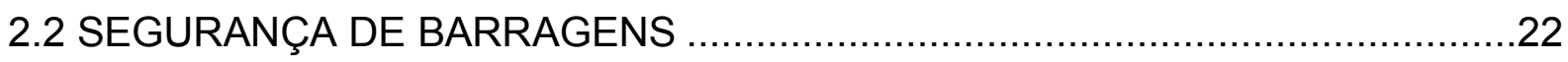

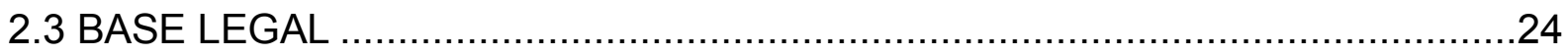

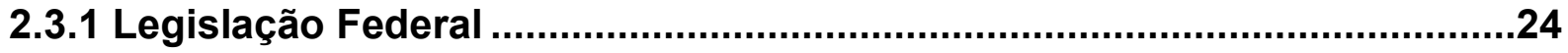

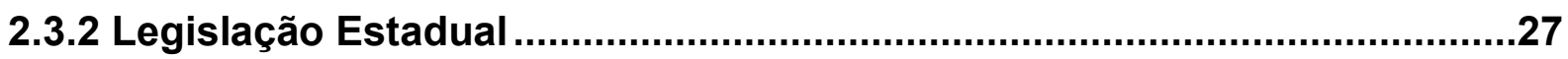

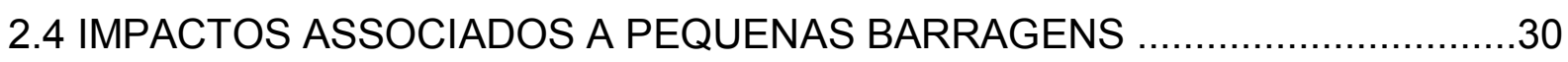

2.4.1 Acidentes ocorridos com pequenas barragens.......................................31

2.5 MÉTODOS PARA IDENTIFICAÇÃO DE MASSAS D'ÁGUA POR

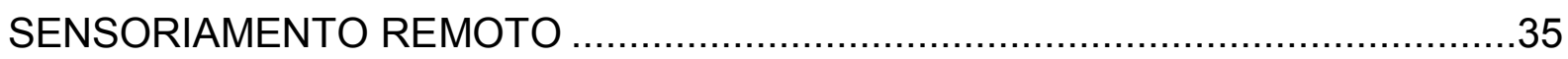

2.6 MÉTODOS PARA ANÁLISE DE RISCO EM BARRAGENS .............................39

2.6.1 Índice de Priorização de Risco para Barragens proposto por Zuffo (2010)

2.6.2 Índice de Segurança de Pequenas Barragens (ISPB) proposto por Pinto (2020)

2.6.3 Segurança dos Vales a Jusante das Barragens: Metodologias de Apoio à Gestão do Risco de acordo com Viseu (2008) ..................................................

3 METODOLOGIA

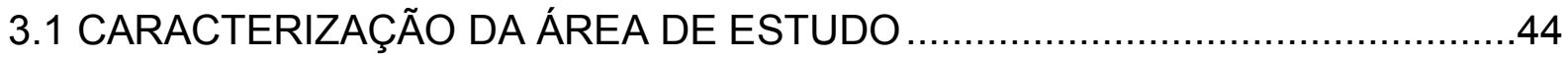

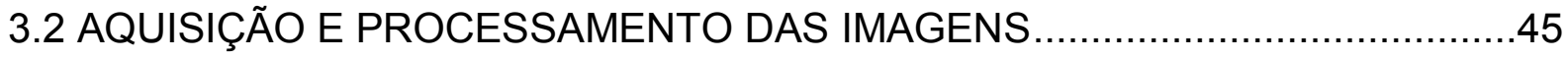

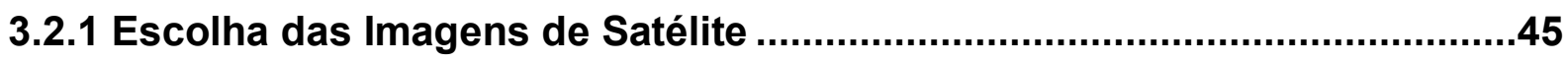

3.2.2 Obtenção e Processamento das Imagens................................................46

3.3 CLASSIFICAÇÃO DAS IMAGENS E EXTRAÇÃO DOS ESPELHOS D'ÁGUA ..47

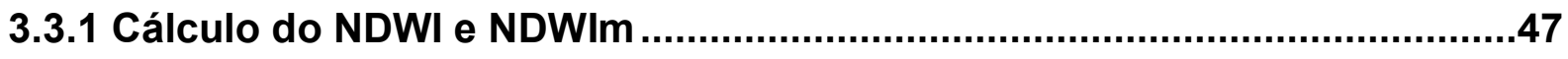

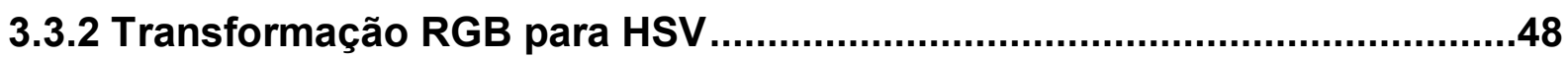

3.3.3 Avaliação da Extração dos Espelhos d'água...............................................48

3.4 DEFINIÇÃO DE CRITÉRIOS E MATRIZ DE HIERARQUIZAÇÃO ......................49 
3.4.1 Critérios Estruturais Relacionados à Barragem (CE) ..............................50

3.4.2 Critérios para caracterização do vale a jusante.......................................53

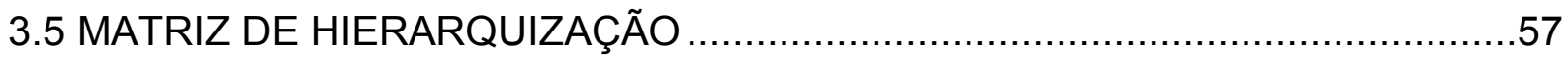

4 RESULTADOS E DISCUSSÃO ...............................................................59

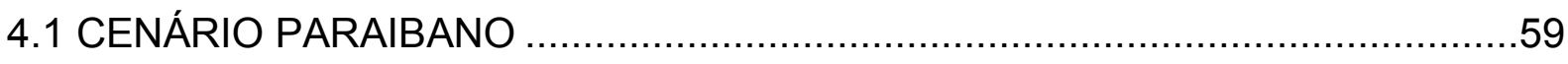

4.2 CENÁRIO MUNICÍPIO DE SUMÉ .......................................................61

4.3 AQUISIÇÃO E PROCESSAMENTO DAS IMAGENS .................................62

4.3.1 Obtenção e Processamento das Imagens de Satélite .................................62

4.4 CLASSIFICAÇÃO DAS IMAGENS E EXTRAÇÃO DOS ESPELHOS D'ÁGUA ..64

4.4.1 Avaliação da Extração dos Espelhos d'água..........................................68

4.4 DEFINIÇÃO DE CRITÉRIOS E MATRIZ DE HIERARQUIZAÇÃO .....................70

4.4.1 Definição da Área para Aplicação da Metodologia...................................70

4.4.2 Análise dos Critérios Estruturais Relacionados à Barragem (CE)............71

4.4.3 Análise dos Critérios para Caracterização do Vale a Jusante.....................73

4.4.3.1 Cálculo do Índice de Risco Associado (IRA) .....................................74

4.4.4 Aplicação da Matriz de Hierarquização ................................................75

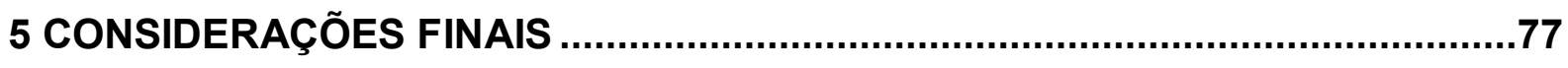

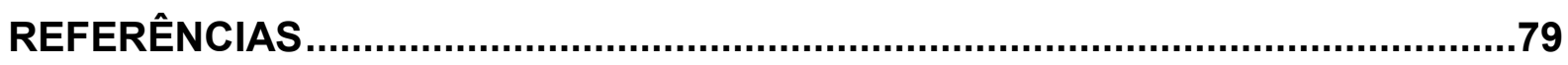

APÊNDICE A - Tutorial para identificação e extração das massas de água através do aplicativo Google Earth Engine

APÊNDICE B - Mapa com a identificação e localização das barragens do município de Sumé. 


\section{INTRODUÇÃO}

As barragens são estruturas onipresentes em rios e córregos no Brasil. Tanto em grandes rios, com a finalidade de geração de energia elétrica, quanto em pequenos afluentes, onde a água barrada, é utilizada para usos múltiplos. De acordo com o Relatório de Segurança de Barragens (RSB), elaborado pela Agência Nacional de Águas e Saneamento Básico (ANA), referente ao ano de 2019, o Brasil tem cadastrado no Sistema Nacional de Informação de Segurança de Barragens (SNISB) 19.388 barragens, das quais $61 \%$ não possuem informações suficientes para definir se a barragem é ou não submetida à Política Nacional de Segurança de Barragens (PNSB) (ANA, 2020).

De acordo com o RSB, em 2019 foram relatados doze acidentes com barragens e 58 incidentes, o maior valor relatado em relação às edições anteriores do relatório. Essas informações e a descrição dos acontecimentos são fornecidas pelos respectivos órgãos fiscalizadores vinculados à ANA. Dos doze acidentes reportados, dez deles foram com pequenas barragens e com características semelhantes: pequenas barragens de terra que romperam em eventos de cheia causando danos materiais (ANA, 2020).

Nesse contexto, as barragens são estruturas construídas em curso permanente ou temporário de água para fins de retenção/acumulação de líquidos ou de misturas de líquidos e sólidos, de maneira segura e controlada. Uma barragem de acumulação de água é classificada como pequena quando apresenta um reservatório com volume inferior a $5 \mathrm{hm}^{3}$ (BRASIL, 2012); barragens que apresentem uma capacidade total do reservatório menor que $3 \mathrm{hm}^{3}$ não são submetidas à PNSB, considerando-se apenas o volume como critério e mesmo barragens não enquadradas na PNSB devem ser cadastradas no SNISB.

Destarte, acidentes com barragens geralmente são eventos de grandes proporções. Na maioria dos casos, geram impactos sociais, econômicos e ambientais. O arranjo espacial dessas estruturas favorece a propagação do desastre em grande escala, pois as margens de rios, afluentes, córregos e vales a jusante são comumente ocupados por núcleos urbanos e demais equipamentos de infraestrutura urbana (LEITE, 2019). 
Dados precisos sobre a distribuição e características de pequenas barragens e seus reservatórios são importantes para fins de conservação de espécies e ecossistemas, gestão de emergências e planejamento de recursos hídricos na bacia hidrográfica, como avaliação correta da capacidade de armazenamento disponível, estimar perdas por evapotranspiração ou atender as necessidades para irrigação (SWAN; GRIFFIN, 2020). Pequenas barragens falham com muito mais frequência do que as maiores, sendo responsáveis pela maior parte do custo anual de rompimentos de barragens; além disso, a falha de pequenas barragens em cascata durante um evento de inundação pode gerar a falha de barragens maiores e mais perigosas a jusante (PISANIELLO, 2009).

Nessa perspectiva, as políticas e os programas de segurança de barragens têm adquirido cada vez mais relevância em todo o mundo. Vários países, inclusive o Brasil, têm se preocupado com o tema, entre eles Estados Unidos, Canadá, Portugal e mais uma lista de 50 países. A evolução tecnológica e os normativos legais relacionados ao assunto não conseguem acompanhar o ritmo acelerado de crescimento dessas estruturas, afetando diretamente os aspectos ligados à segurança das barragens (PERSECHINI et al., 2015).

Em vista disso, o aumento da discussão no tocante aos riscos impostos à sociedade como consequência da implantação de reservatórios vem demandando uma maior atuação das autoridades constituídas e maior preparo dos proprietários de barragens, não sendo suficiente apenas a busca pelo atendimento aos critérios normatizados por parte dos empreendedores, como valores mínimos de resistência e de fatores de segurança. São necessários processos regulatórios mais severos e a definição de mecanismos e indicadores de desempenho que promovam uma melhor gestão dessas estruturas (LEITE, 2019).

Dessa forma, um processo de fiscalização e avaliação da segurança de pequenas barragens é um instrumento indispensável no contexto do monitoramento dessas estruturas, contribuindo para o processo de gestão e acompanhamento dos indicadores demandados pela Organização das Nações Unidas (ONU), descritos no Objetivo de Desenvolvimento Sustentável (ODS) 6 - Água Potável e Saneamento.

Assim, a proposta deste estudo é elaborar um Grau de Hierarquização $(\mathrm{GH})$ para ações de fiscalização dos órgãos gestores de recursos hídricos em pequenos 
barramentos que não estão registrados no SNISB e auxiliar na organização das ações de fiscalização, uma vez que um processo inadequado gera impactos negativos para o ambiente regulatório e, consequentemente, para a sociedade.

\subsection{OBJETIVO}

\subsubsection{Objetivo Geral}

Estabelecer um Grau de Hierarquização para direcionar ações de fiscalização em pequenas barragens de água, baseado em critérios de risco potencial e dano potencial possível associado às barragens, com o auxílio de ferramentas de sensoriamento remoto, para subsidiar as ações dos órgãos estaduais gestores de recursos hídricos no estado da Paraíba.

\subsubsection{Objetivos Específicos}

- Identificar e caracterizar as massas d'água com o auxílio de ferramentas de sensoriamento remoto;

- Classificar as barragens em categorias de risco potencial;

- Classificar os danos potenciais possíveis nos vales a jusante. 


\section{FUNDAMENTAÇÃO TEÓRICA}

\subsection{BARRAGENS NO BRASIL}

No Brasil, os barramentos de cursos d'água artificiais foram utilizados desde cedo para a adaptação da civilização ao ambiente natural e a melhoria da qualidade de vida das populações. Há cinco mil anos, as barragens têm servido para acumulação de água e rejeitos, regulação de vazão, mineração, irrigação, abastecimento humano, fins industriais e atenuação de eventos extremos como secas e cheias (ANA, 2017).

Em vista disso, são implantadas em cursos d'água e, em decorrência desse fato, interagem diretamente com os aspectos relacionados à gestão dos recursos hídricos e ao meio ambiente. Por essa razão, precisam estar em consonância com as principais políticas nacionais, como a Política Nacional do Meio Ambiente (PNMA) e a Política Nacional de Recursos Hídricos (PNRH): a primeira tem como objetivo preservação, melhoria e recuperação da qualidade ambiental propícia à vida, visando assegurar, no país, condições ao desenvolvimento socioeconômico, interesses da segurança nacional e proteção da dignidade da vida humana (BRASIL, 1981).

Existem diversos benefícios associados à construção das barragens, porém são necessárias normas que garantam o máximo de segurança possível preconizando os fundamentos estabelecidos pela Política Nacional de Recursos Hídricos (PNRH), conforme artigo $1^{\circ}$ (BRASIL, 1997):

\footnotetext{
I - a água é um bem de domínio público;

II - a água é um recurso natural limitado, dotado de valor econômico;

III - em situações de escassez, o uso prioritário dos recursos hídricos é o consumo humano e a dessedentação de animais;

IV - a gestão dos recursos hídricos deve sempre proporcionar o uso múltiplo das águas;

V - a bacia hidrográfica é a unidade territorial para implementação da Política Nacional de Recursos Hídricos e atuação do Sistema Nacional de Gerenciamento de Recursos Hídricos;

$\mathrm{VI}$ - a gestão dos recursos hídricos deve ser descentralizada e contar com a participação do Poder Público, dos usuários e das comunidades.
}

A Política Nacional de Segurança de Barragens (PNSB) e o Sistema Nacional de Informações sobre Segurança de Barragens (SNISB) foram criados pela Lei Federal $n^{\circ} 12.334 / 2010$, considerada o marco regulatório sobre o tema no Brasil. O 
objeto de aplicação da lei são barragens destinadas à acumulação de água para quaisquer usos, disposição final ou temporária de rejeitos da mineração e acumulação de resíduos industriais que apresentem pelo menos uma das seguintes características:

I - altura do maciço, medida do encontro do pé do talude de jusante com o nível do solo até a crista de coroamento do barramento, maior ou igual a 15 (quinze) metros;

II - capacidade total do reservatório maior ou igual a $3.000 .000 \mathrm{~m}^{3}$ (três milhões de metros cúbicos);

III - reservatório que contenha resíduos perigosos conforme normas técnicas aplicáveis;

IV - categoria de dano potencial associado médio ou alto, em termos econômicos, sociais, ambientais ou de perda de vidas humanas, conforme definido no art. $7^{\circ}$ desta Lei;

$\mathrm{V}$ - categoria de risco alto, a critério do órgão fiscalizador, conforme definido no art. $7^{\circ}$ desta Lei (BRASIL, 2010).

Um dos instrumentos descritos na PNSB é o Relatório de Segurança de Barragens (RSB) que é elaborado, anualmente, sob a coordenação da Agência Nacional de Águas e Saneamento Básico (ANA), baseando-se em informações enviadas pelas 33 entidades fiscalizadoras de segurança de barragens (ANA, 2020).

No período de abrangência desse RSB - 2019, constam cadastradas no SNISB 19.388 barragens, das quais 8.559 (ou 44\%) possuem informação de altura, 15.821 (ou 82\%) informação de volume e 8.763 (ou 45\%) com algum tipo de ato de autorização (outorga, concessão, autorização, licença, entre outros), estando, portanto, regularizadas (ANA, 2020).

Cada barragem cadastrada no SNISB recebe uma classificação para indicar o quão completos estão os seus dados, descrita a seguir:

- Mínima: barragens que possuem apenas o nome, coordenadas, UF, município e o uso principal;

- Baixa: dados da categoria mínima + altura, capacidade e empreendedor;

- Média: dados da categoria baixa + autorização;

- Boa: dados da categoria média + classificação quanto à Categoria de Risco (CRI) e Dano Potencial Associado (DPA);

- Ótima: dados da categoria boa + inspeção regular, revisão periódica (+ PAE se o DPA for alto). 
É possivel observar na Figura 1 que $67 \%$ das barragens cadastradas no SNISB apresentam apenas os dados mínimos necessários; não existem informações suficientes para enquadrar essas barragens na PNSB. Essa é uma demanda latente dos órgãos fiscalizadores, principalmente quando a informação é sobre pequenas barragens de acumulação de água.

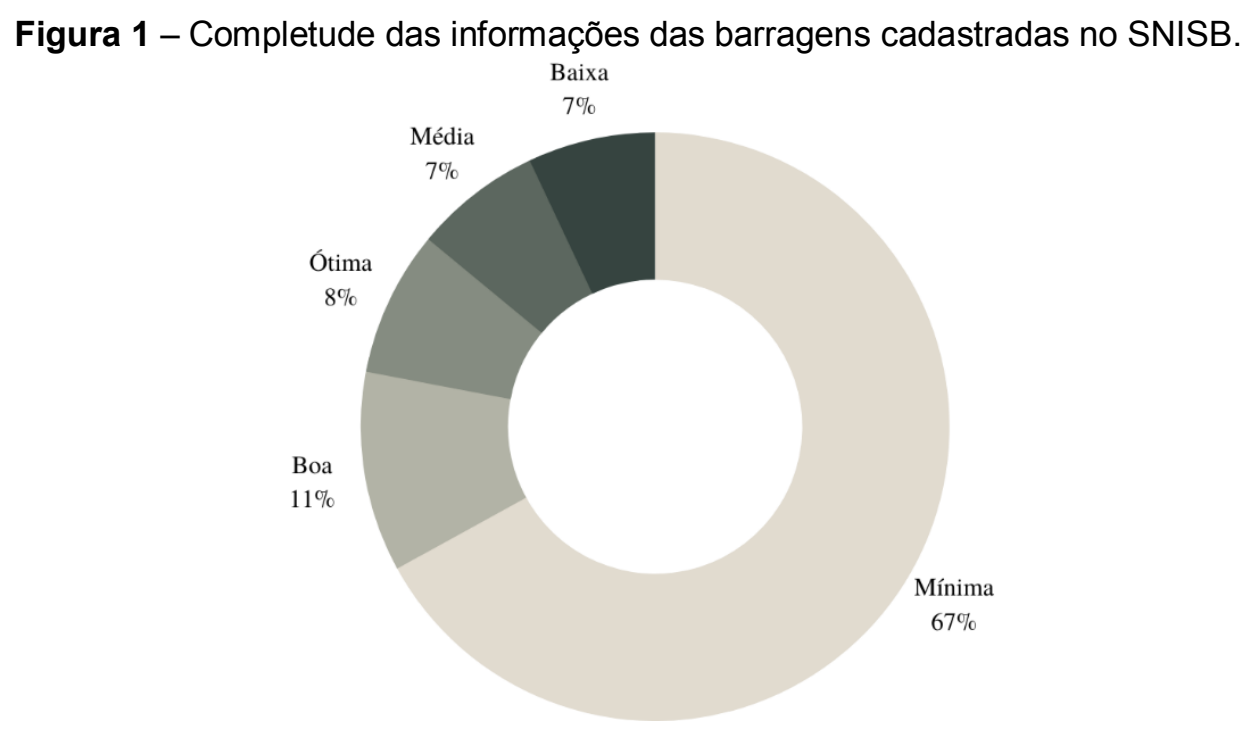

Fonte: Adaptado de ANA (2020).

A definição, por parte do órgão fiscalizador, se a barragem se submete ou não à PNSB, é fundamental para efetiva implementação dos instrumentos descritos na política e para que a sociedade tenha seu direito à informação garantido, permitindo, assim, a cobrança e fiscalização por parte dos órgãos gestores aos empreendedores quanto à manutenção da segurança de seus empreendimentos, seja no aspecto estrutural ou documental (ANA, 2020).

Para fins de classificação, é importante analisar alguns dados básicos relativos às barragens submetidas à PNSB e cadastradas no SNISB, tais como dados relativos à altura, uso principal, volume das barragens e material de construção. Na Figura 2, verificou-se que $50 \%$ das barragens submetidas à PNSB têm altura inferior a 15 metros e $20 \%$ não apresentam essa informação, que é uma das principais características técnicas para fins de classificação de risco. 
Figura 2 - Altura das barragens cadastradas no SNISB submetidas à PNSB.

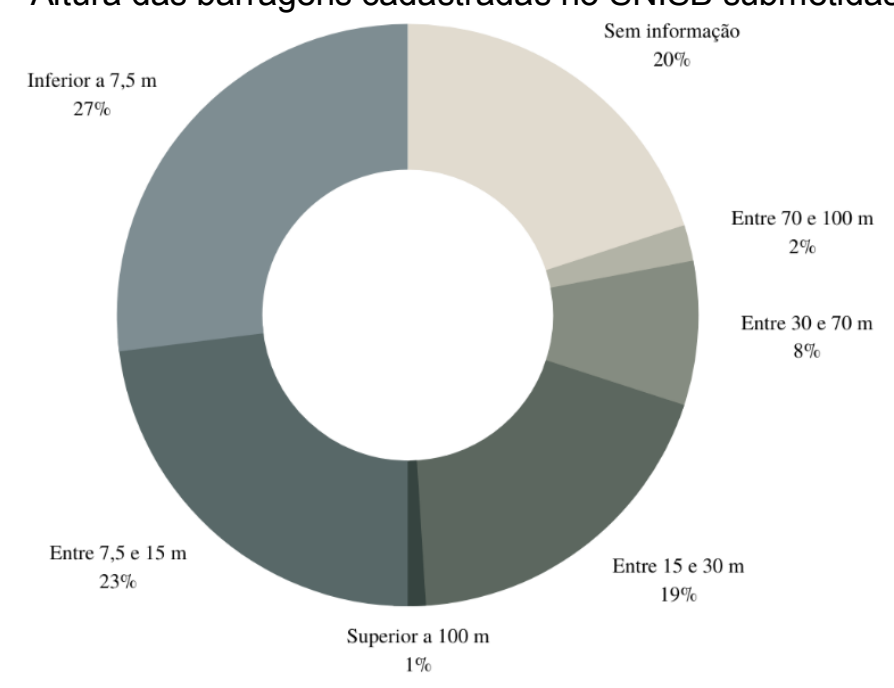

Fonte: Adaptado de ANA (2020).

Em relação ao volume, $62 \%$ das barragens são classificadas como pequenas, segundo classificação definida pela Resolução n 143/2012 do Conselho Nacional de Recursos Hídricos (CNRH), com um volume inferior ou igual a $5 \mathrm{hm}^{3}$, sendo que, desse total, $40 \%$ apresentam um volume de até $1 \mathrm{hm}^{3}$. Somente $5 \%$ das barragens cadastradas não apresentam informações sobre volume, conforme dados apresentados na Figura 3.

Figura 3 - Volume das barragens cadastradas no SNISB submetidas à PNSB.

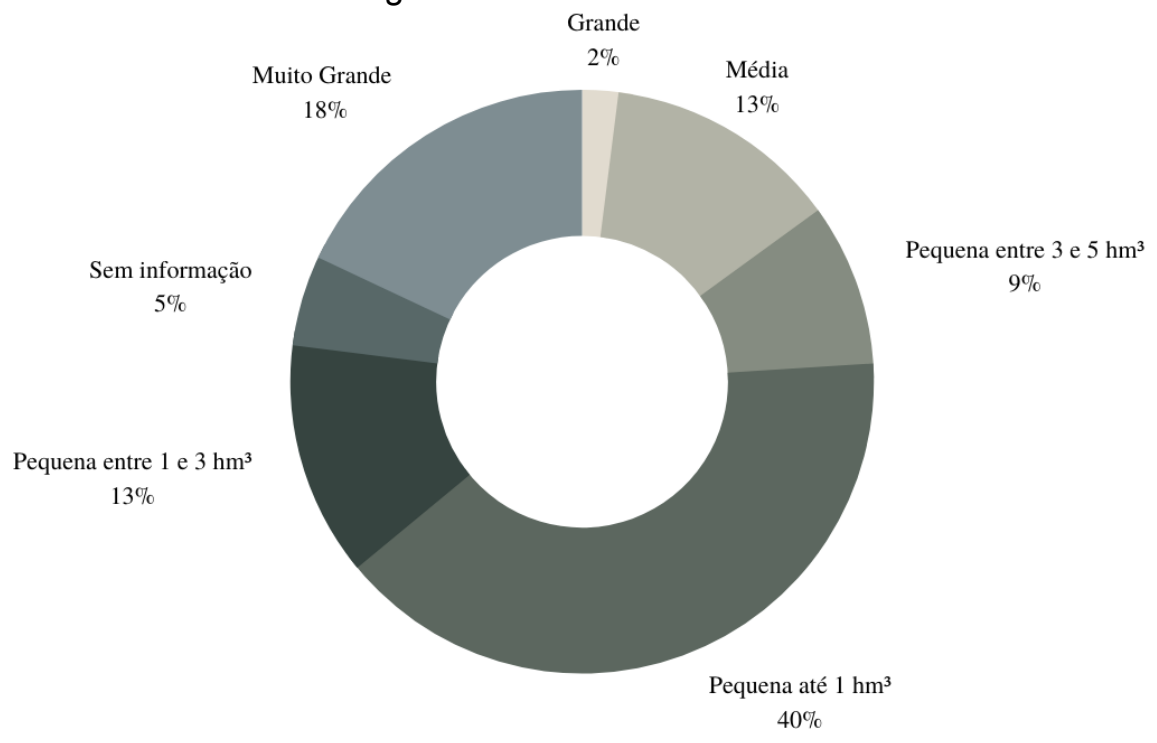

Fonte: Adaptado de ANA (2020). 
Em relação ao material construtivo, $56 \%$ das barragens foram construídas em Terra. Em 28\% dos registros não existe essa informação, conforme apresentado na Figura 4.

Figura 4 - Tipo de material construtivo das barragens cadastradas no SNISB submetidas à PNSB.

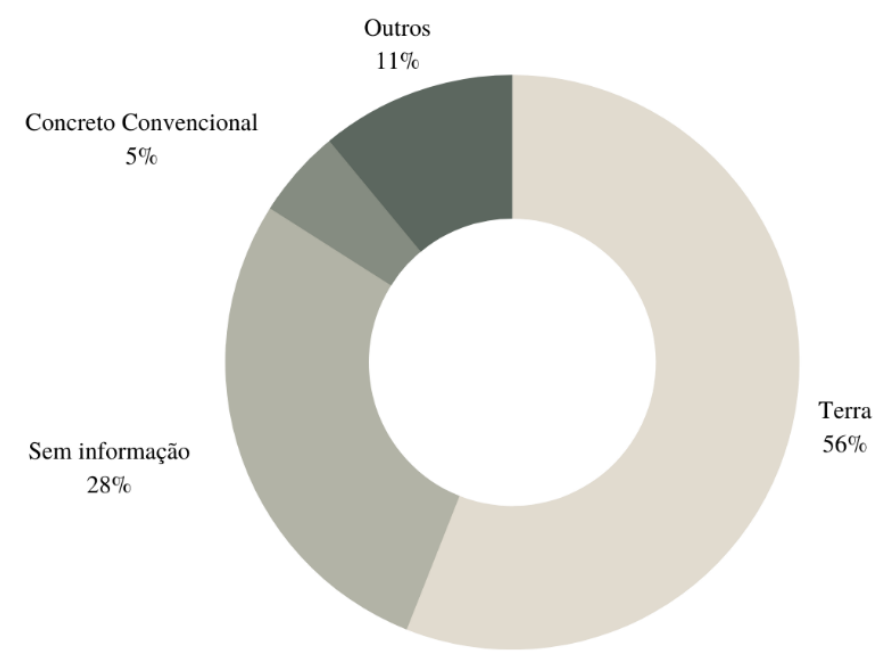

Fonte: Adaptado de ANA (2020).

$\mathrm{Na}$ Figura 5, observa-se qual o uso principal das barragens submetidas à PNSB, sendo os maiores usos ligados à irrigação, com 33,7\%, ao abastecimento humano, com $21,4 \%$, e à geração de energia elétrica, com $16,7 \%$.

Figura 5 - Uso principal das barragens cadastradas no SNISB submetidas à PNSB.

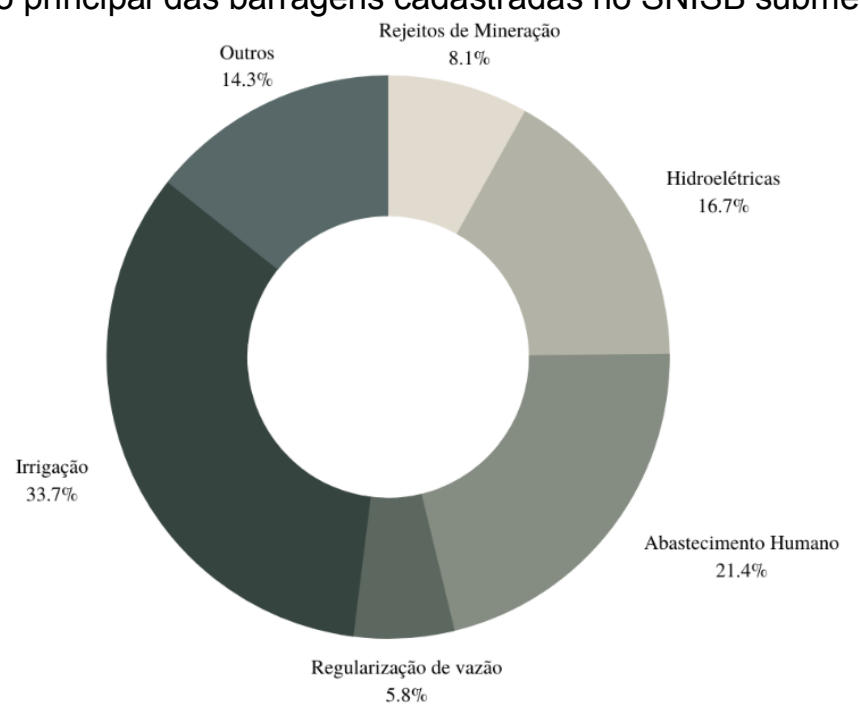

Fonte: Adaptado de ANA (2020). 
Diante desse cenário, identifica-se um perfil das barragens submetidas à PNSB: são barragens pequenas, com volume inferior a $3 \mathrm{hm}^{3}$, de terra, com finalidade para irrigação e com altura inferior a quinze metros. Assim, a grande maioria não apresenta características técnicas de altura e volume suficientes para serem submetidas à PNSB, sendo a classificação devida ao Dano Potencial Associado (DPA), que leva em consideração impactos ambientais e socioeconômicos (ANA, 2020).

Ainda há muito trabalho a ser feito no processo de realização de cadastro de barragens, identificação de empreendedores e classificação, especialmente quando se considera que existem 19.388 barragens cadastradas no SNISB e, de acordo com o Relatório de Conjuntura dos Recursos Hídricos do Brasil (2018), há mais 170 mil espelhos d'água identificados com área menor que cinco hectares no Brasil. Outrossim, mesmo que as barragens sejam submetidas à PNSB, é necessário que se tenha o cadastro correto do empreendimento no SNISB visando uma adequada gestão dos recursos hídricos no país (ANA, 2020).

Dessa forma, acidentes com pequenas barragens têm menor repercussão, mas são mais frequentes que os ocorridos com grandes barragens. A falta de manutenção dessas estruturas pode levar a rompimentos e danos ambientais, sociais e econômicos. Por conseguinte, a identificação e avaliação desses empreendimentos são ferramentas indispensáveis para ações de monitoramento e controle de possíveis sinistros (PINTO, 2020).

\subsection{SEGURANÇA DE BARRAGENS}

De acordo com organizações internacionais como a Internacional Commission on Large Dams (ICOLD), o Banco Mundial (World Bank), a Comissão Mundial de Barragens (World Commission on Dams) e o Comitê Brasileiro de Barragens (CBDB), as condições de segurança são amplamente atendidas quando a barragem mantém boas condições estruturais, não causa danos ambientais e não ameaça a população que mora nas regiões próximas ao empreendimento (MEDEIROS, 2013).

Com dimensões continentais e uma extensa rede fluvial, o Brasil possui diversos barramentos para os mais diversos usos, dando subsídio, assim, para o 
desenvolvimento socioeconômico do país. Essa diversidade de dimensões e finalidades dos barramentos gera entraves técnicos nos processos de manutenção dessas estruturas, dificultando o atendimento às normas nacionais e internacionais que determinam os níveis de segurança das barragens (DUARTE, 2008).

A adequação entre projeto, manutenção, operação e o atendimento a critérios técnicos e estruturais são fatores determinantes para que uma barragem seja considerada segura, bem como o potencial de danos, levando em consideração uma hipotética ruptura, deve ser avaliado considerando a área de influência a montante e a jusante do empreendimento, de maneira que é possível avaliar o barramento pela sua qualidade tecnológica e sua inserção no espaço (AGUIAR et al., 2015).

Associada a essa proliferação de barragens, tem-se um vertiginoso crescimento populacional, submetido a políticas habitacionais inexpressivas, levando a população mais desassistida a ocupar áreas inundáveis a jusante, elevando o potencial de perdas de vidas humanas e bens materiais. Acidentes recentes ocorridos no Brasil demonstram a ausência do poder público e como essas questões precisam ser tratadas de forma mais efetiva por empreendedores e órgãos fiscalizadores (LEITE, 2019).

$\mathrm{Na}$ última década, o Brasil passou por diversas catástrofes no âmbito de acidentes com barragens, sendo o mais grave deles o rompimento da barragem de rejeito na região do Córrego do Feijão, no município brasileiro de Brumadinho, a 65 km de Belo Horizonte, em Minhas Gerais, em 25 de janeiro de 2019. No entanto, outros acidentes históricos já tinham sido determinantes para a criação de procedimentos de segurança mais eficazes, como os eventos ocorridos em Orós (CE), nos anos de 1960; Euclides da Cunha (SP) e Limoeiro (SP), nos anos de 1970; e Cataguazes (MG), em 2003 (PERSECHINI et al., 2015).

Nessa senda, Biedermann (1997) explica que a segurança de barragens é obtida através de três pilares básicos: segurança estrutural (projeto, construção e manutenção adequados), monitoramento e gestão de emergência. As ações de monitoramento só são consideradas efetivas se, quando detectadas anomalias, estas forem tratadas em tempo hábil. A segurança só pode ser garantida quando medidas integradas de gerenciamento de risco são adotadas pelos principais atores do 
processo, a saber: responsáveis pelas barragens, instituições reguladoras e a sociedade (LEITE, 2019).

\subsection{BASE LEGAL}

\subsubsection{Legislação Federal}

No Brasil, o marco regulatório para segurança de barragens é a Lei $n^{0} 12.334$, de 20 de setembro de 2010, alterada pela Lei $n^{\circ}$ 14.066, de 30 de setembro de 2020, que estabelece a Política Nacional de Segurança de Barragens (PNSB) e cria o SNISB, destinada a barragens de acumulação de água para quaisquer usos e disposição final ou temporária de rejeitos industriais ou de mineração. No exame do arcabouço jurídico-institucional de recursos hídricos brasileiros não havia, até esta data, no âmbito nacional, nenhuma indicação de responsabilidade direta pela fiscalização de segurança de barragens (NEVES, 2018).

A criação da referida lei forneceu um conjunto de procedimentos que subsidiam à segurança de barragens, minimização da ocorrência de acidentes, regulamentação de ações de emergência, coleta e manutenção de informações sobre segurança de barragens e fomentam a cultura de segurança entre empreendedores, órgãos fiscalizadores e a sociedade em geral.

Uma importante definição descrita na referida lei é o Dano Potencial Associado (DPA), descrito como:

Dano que pode ocorrer devido a rompimento, vazamento, infiltração no solo ou mau funcionamento de uma barragem, independentemente da sua probabilidade de ocorrência, a ser graduado de acordo com as perdas de vidas humanas e os impactos sociais, econômicos e ambientais (BRASIL, 2010).

De modo a disciplinar e monitorar as ações empregadas no tocante ao tema pelos responsáveis por barragens, a lei faz uso dos instrumentos descritos no seu Capítulo IV, art. $6^{\circ}$ :

I - o sistema de classificação de barragens por categoria de risco e por dano potencial associado;

II - o Plano de Segurança da Barragem, incluído o PAE;

III - o Sistema Nacional de Informações sobre Segurança de Barragens (SNISB); 
IV - o Sistema Nacional de Informações sobre o Meio Ambiente (Sinima);

V - o Cadastro Técnico Federal de Atividades e Instrumentos de Defesa Ambiental;

VI - o Cadastro Técnico Federal de Atividades Potencialmente Poluidoras ou Utilizadoras de Recursos Ambientais;

VII - o Relatório de Segurança de Barragens.

VIII - o Sistema Nacional de Informações sobre Recursos Hídricos

IX - o monitoramento das barragens e dos recursos hídricos em sua área de influência;

X - os guias de boas práticas em segurança de barragens (BRASIL, 2010).

Com o intuito de complementar e auxiliar no cumprimento dos objetivos da PNSB, outras legislações foram criadas e as principais são as Resoluções $n^{\circ} 144$ e n 143 de 2012, ambas do Conselho Nacional de Recursos Hídricos (CNRH). A primeira estabelece as diretrizes para implementação da PNSB, aplicação de seus instrumentos e atuação do SNISB, determinando os itens mínimos que devem constar no Relatório de Segurança de Barragens (RSB) e os prazos que devem ser seguidos por empreendedores e órgãos fiscalizadores.

A segunda resolução estabelece os critérios gerais para classificação de barragens por Categoria de Risco (CR), DPA e pelo seu volume. A classificação fica a critério do órgão fiscalizador, cabendo a ele, após realiza-la, comunicar ao empreendedor a categoria em que a barragem foi enquadrada. Quanto à CR, as barragens são classificadas de acordo com aspectos técnicos da própria barragem que possam influenciar na ocorrência de acidentes. Na Tabela 1 são listados os critérios gerais:

Tabela 1 - Critérios gerais para classificação quanto à CR segundo a Resolução n 143/2012 do CNRH.

\begin{tabular}{|c|c|c|}
\hline Características Técnicas & $\begin{array}{c}\text { Estado de Conservação da } \\
\text { Barragem }\end{array}$ & $\begin{array}{c}\text { Plano de Segurança da } \\
\text { Barragem }\end{array}$ \\
\hline a) altura do barramento; & $\begin{array}{l}\text { a) confiabilidade das estruturas } \\
\text { extravasoras; }\end{array}$ & $\begin{array}{l}\text { a) existência de documentação } \\
\text { de projeto; }\end{array}$ \\
\hline $\begin{array}{l}\text { b) comprimento do coroamento } \\
\text { da barragem; }\end{array}$ & $\begin{array}{l}\text { b) confiabilidade das estruturas } \\
\text { de captação; }\end{array}$ & $\begin{array}{l}\text { b) estrutura organizacional e } \\
\text { qualificação dos profissionais } \\
\text { da equipe técnica de } \\
\text { segurança da barragem; }\end{array}$ \\
\hline $\begin{array}{l}\text { c) tipo de barragem quanto ao } \\
\text { material de construção; }\end{array}$ & c) eclusa; & $\begin{array}{l}\text { c) procedimentos de inspeções } \\
\text { de segurança e de } \\
\text { monitoramento; }\end{array}$ \\
\hline $\begin{array}{l}\text { d) tipo de fundação da } \\
\text { barragem; }\end{array}$ & d) percolação; & $\begin{array}{l}\text { d) regra operacional dos } \\
\text { dispositivos de descarga da } \\
\text { barragem; }\end{array}$ \\
\hline e) idade da barragem; & e) deformações e recalques; & $\begin{array}{l}\text { e) relatórios de inspeção de } \\
\text { segurança com análise e } \\
\text { interpretação. }\end{array}$ \\
\hline
\end{tabular}


Fonte: Adaptado de BRASIL (2012a).

No seu art. $5^{\circ}$, a Resolução descreve os critérios gerais que devem ser utilizados para classificação quanto ao dano potencial associado na área afetada pelo possível rompimento da barragem:

I- existência de população a jusante com potencial de perda de vidas humanas;

II- existência de unidades habitacionais ou equipamentos urbanos ou comunitários;

III- existência de infraestrutura ou serviços;

IV- existência de equipamentos de serviços públicos essenciais;

V- existência de áreas protegidas definidas em legislação;

VI- natureza dos rejeitos ou resíduos armazenados;

VII- volume (BRASIL, 2012a).

A classificação quanto ao volume é descrita no art. $7^{\circ}$, onde as barragens são distribuídas em quatro classes:

I- pequena: reservatório com volume inferior a 5 milhões de metros cúbicos; II- média: reservatório com volume igual ou superior a 5 milhões de metros cúbicos e igual ou inferior a 75 milhões de metros cúbicos;

III- grande: reservatório com volume superior a 75 milhões de metros cúbicos e inferior ou igual a 200 milhões de metros cúbicos.

IV- muito grande: reservatório com volume superior a 200 milhões de metros cúbicos (BRASIL, 2012a).

Compete à Agência Nacional de Águas e Saneamento Básico (ANA), no âmbito das suas atribuições, classificar as barragens por ela outorgadas. Também são classificadas como órgãos fiscalizadores no âmbito federal a Agência Nacional de Energia Elétrica (ANEEL), que fiscaliza e regula as barragens com finalidade para geração de energia elétrica, e a Agência Nacional de Mineração (ANM), que regula as barragens utilizadas nos processos de mineração (ANA, 2020).

A ANA possui duas Resoluções que regulamentam a fiscalização de barragens sobre sua jurisdição: Resolução $n^{\circ}$ 236/2017, que estabelece a periodicidade de execução e atualização, o conteúdo mínimo do Plano de Segurança da Barragem (PSB), das Inspeções de Segurança Regular e Especial (ISR e ISE), da Revisão Periódica de Segurança de Barragem (RPSB) e do Plano de Ação de Emergência (PAE); e a Resolução $n^{\circ}$ 132/2016, que estabelece critérios complementares de 
classificação de barragens reguladas pela ANA, quanto ao DPA, referentes ao Impacto Ambiental e ao Impacto Socioeconômico.

\subsubsection{Legislação Estadual}

Na esfera estadual, a responsabilidade pela fiscalização das barragens de acumulação de água é do órgão estadual gestor de recursos hídricos; já quanto às barragens para fins industriais e rejeitos de mineração, a responsabilidade é do órgão responsável pela outorga e licenças expedidas (ANA, 2020). Na Figura 6 está apresentada de forma resumida as entidades fiscalizadoras de barragens no Brasil.

Figura 6 - Entidades fiscalizadoras de segurança de barragens.

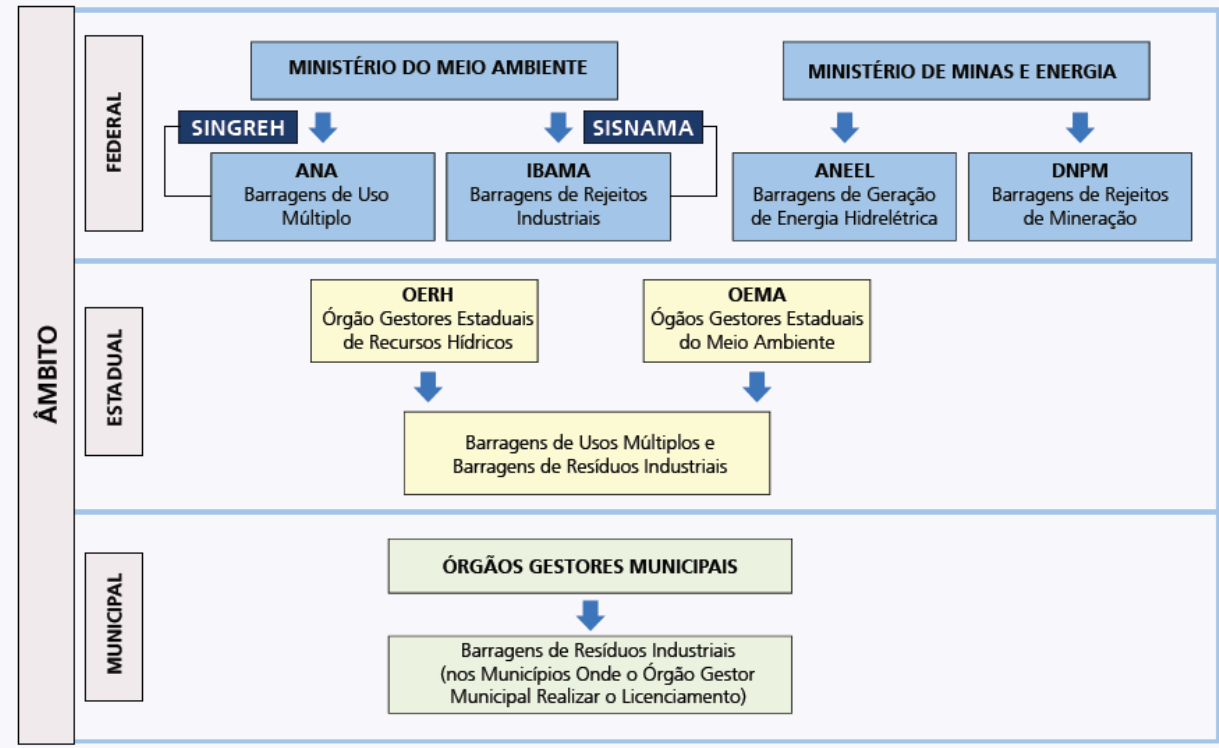

Fonte: Adaptado de ANA (2017).

A integração entre o sistema nacional e estadual acontece através do Programa de Consolidação do Pacto Nacional pela Gestão das Águas no Brasil (Progestão), que é regulamentado por meio da Resolução ANA n 379/2013 e tem como princípio do pagamento por alcance de metas a partir da adesão voluntária dos órgãos estaduais gestores de recursos hídricos. O Progestão é desenvolvido pela Agência Nacional de Águas (ANA) em apoio aos Sistemas Estaduais de Gerenciamento de Recursos Hídricos (SEGREHs) que integram o Sistema Nacional de Gerenciamento de Recursos Hídricos (SINGREH), tendo como objetivos (ANA, 2016): 
- Promover a efetiva articulação entre os processos de gestão das águas e de regulação dos seus usos, conduzidos nas esferas nacional e estadual; e

- Fortalecer o modelo brasileiro de governança das águas, integrado, descentralizado e participativo.

Para o cumprimento de seus objetivos, o programa aporta recursos orçamentários da ANA na forma de transferência pelo alcance de metas acordadas entre a ANA e as entidades estaduais, sendo interveniente o Conselho Estadual de Recursos Hídricos (CERH). Dentro do Quadro de Metas de Cooperação Federativa no Âmbito do Sistema Nacional de Gerenciamento de Recursos Hídricos (SINGREH), é a atuação para segurança de barragens através do cumprimento de exigências relativas à implementação da PNSB e tem por objetivo a observância dos dispositivos legais e normativos da PNSB e do SNISB, com a estruturação de um cadastro desses empreendimentos e sua classificação (ANA, 2015).

No estado da Paraíba, a Lei n 6.308, de 02 de julho de 1996, institui a Política Estadual de Recursos Hídricos que tem como objetivo assegurar o uso desses recursos de forma racional e integrada, promovendo desenvolvimento e o bem-estar da população do Estado da Paraíba, baseando-se nos seguintes princípios, conforme o art. $2^{\circ}$ :

I - O acesso aos Recursos Hídricos é direito de todos e objetiva atender às necessidades essenciais da sobrevivência humana.

II - Os recursos hídricos são um bem público, de valor econômico, cuja utilização deve ser tarifada.

III - A bacia hidrográfica é uma unidade básica físico-territorial de planejamento e gerenciamento dos Recursos Hídricos.

IV - O gerenciamento dos Recursos Hídricos far-se-á de forma participativa e integrada, considerando os aspectos quantitativos e qualitativos desses Recursos e as diferentes fases do ciclo hidrológico.

$\mathrm{V}$ - O aproveitamento dos Recursos Hídricos deverá ser feito racionalmente de forma a garantir o desenvolvimento e a preservação do meio ambiente. VI - O aproveitamento e o gerenciamento dos Recursos Hídricos serão utilizados como instrumento de combate aos efeitos adversos da poluição, da seca, de inundações, do desmatamento indiscriminado, de queimadas, da erosão e do assoreamento (PARAíBA, 1996).

O Decreto $n^{\circ} 19.258$, de 31 de outubro de 1997 regulamenta o controle técnico das obras e serviços de oferta hídrica no estado, onde são definidos dois conceitos importantes para a temática em questão: de açude e de barragem de Derivação ou Regularização de Nível d'água, como descrito a seguir: 
I - açude: a estrutura hidráulica composta da barragem de um curso d'água e o lago por ele formado;

II - transposição de Água Bruta: a estrutura hidráulica compreendendo canal ou tubulação, destinada a transferir água entre duas unidades hidrográficas distintas;

III - barragem de Derivação ou Regularização de Nível d'água - a estrutura hidráulica, disposta no leito dos rios, interceptando a corrente líquida natural ou regularizada;

IV - poço: a estrutura escavada ou perfurada no solo para captação de água subterrânea (PARAÍBA, 1997).

Para fins de aplicação do regulamento, tem-se a seguinte classificação em seu Capítulo III, art. $3^{\circ}$, quanto ao volume hidráulico acumulável e quanto à superfície da bacia hidrográfica, como apresentado na Tabela 2.

Tabela 2 - Classificação quanto ao volume hidráulico e à superfície hidrográfica.

\begin{tabular}{ccc}
\hline Classe & Volume Hidráulico $\left(\mathrm{hm}^{3}\right)$ & $\begin{array}{c}\text { Superfície Hidrográfica } \\
\left(\mathrm{km}^{2}\right)\end{array}$ \\
\hline Micro & Até 0,5 & Até 3 \\
Pequeno & Acima de 0,5 até 7,5 & Acima de 3 até 50 \\
Médio & Acima de 7,5 até 75 & Acima de 50 até 500 \\
Grande & Acima de 75 até 750 & Acima de 500 até 5.000 \\
Macro & Acima de 750 & Acima de 5.000 \\
\hline
\end{tabular}

Fonte: Adaptado de Paraíba (1997).

No dia 05 de fevereiro de 2019, foi publicado o Decreto $n^{\circ} 39.014$, que "dispõe sobre o cadastramento de obras hídricas construídas e pendentes de regularização até o advento do presente Decreto, para fins de concessão de licenciamento". O objetivo do Decreto, descrito em seu art. $1^{\circ}$, é a regularização de obras hídricas com vistas a identificar o empreendimento e o empreendedor das obras existentes até o momento atual e, com isso, garantir a efetividade da aplicação da PNSB. Os empreendedores devem se regularizar de forma autodeclaratória através de requerimentos disponibilizados pela Agência Executiva de Gestão das Águas do Estado da Paraíba (AESA) (PARAÍBA, 2019).

Outros normativos sobre o tema no estado são as Resoluções AESA n 03, de 11 de fevereiro de 2016, e a $n^{\circ} 04$, de 25 de novembro de 2016. A primeira define periodicidade, qualificação da equipe responsável, conteúdo mínimo e nível de detalhamento das inspeções de segurança regular e especial de Barragem. De acordo com os critérios definidos na Resolução, a periodicidade das inspeções é definida em 
termos de Categoria de Risco (CR) e Dano Potencial (DP), apresentados no Quadro 1.

Quadro 1 - Periodicidade mínima dos ciclos de inspeções.

\begin{tabular}{|l|l|l|l|}
\hline CR DP & \multicolumn{1}{|c|}{ Alto } & \multicolumn{1}{|c|}{ Médio } & \multicolumn{1}{c|}{ Baixo } \\
\hline Alto & Semestral $^{1}$ & Semestral & Anual \\
\hline Médio & Semestral $^{1}$ & Anual & Anual \\
\hline Baixo & Semestral ${ }^{1}$ & Anual & Bianual \\
\hline \multicolumn{4}{|c|}{ Fonte: Adaptado de Paraíba (2016). $^{1}$ Independe do risco } \\
\hline
\end{tabular}

Enquanto isso, a segunda define periodicidade de atualização, qualificação do responsável técnico, conteúdo mínimo e nível de detalhamento do Plano de Segurança da Barragem e da Revisão Periódica de Segurança da Barragem. Ainda assim, para que haja o desenvolvimento de uma cultura de segurança de barragens, a existência da legislação por si não é suficiente, sendo necessária a independência dos órgãos fiscalizadores, o aporte de recursos necessários, um corpo técnico capacitado e em número compatível com a quantidade de barragens que precisam ser fiscalizadas dentro de suas competências (LEITE, 2019).

\subsection{IMPACTOS ASSOCIADOS A PEQUENAS BARRAGENS}

Conforme dados dos Boletins do Comitê Internacional de Grandes Barragens (ICOLD), as principais causas de ruptura em barragens de terra são as seguintes:

a) Erosões por transbordamento ou galgamento, causadas por capacidade inadequada de vertedouros ou pelo não funcionamento de seus órgãos de controle;

b) Erosão interna ("piping") pela fundação, pelo corpo da barragem ou ao longo de interfaces barragem - estruturas;

c) Resistência insuficiente dos materiais, especialmente por superfícies de descontinuidade pela fundação;

d) "Liquefação" de areias saturadas, ocasionadas por sismos; 
e) Trincas e fissuras devidas a recalques e/ou ressecamento dos solos, com os efeitos resultantes de erosão interna;

f) Pressão da água muito alta nos poros do solo ou nas fraturas das rochas.

Doze acidentes com barragens e 58 incidentes em quinze diferentes estados no Brasil foram identificados no RSB (2019) - o quantitativo é superior ao observado nos relatórios anteriores. Esse aumento pode ter ocorrido por diversos fatores, como aumento de eventos extremos de cheias, más condições de conservação das barragens e aumento nos processos de fiscalização (ANA, 2020).

Existem custos tangíveis e intangíveis, associados aos acidentes, que devem ser considerados. Os custos tangíveis estão diretamente relacionados às perdas econômicas, ao passo que os custos intangíveis estão relacionados às pessoas e à sociedade como um todo. Pode-se citar como exemplo de custos intangíveis o trauma causado por conta do acidente, interrupção no funcionamento da infraestrutura da região e dos serviços essenciais, destruição de recursos culturais e históricos, atraso no desenvolvimento econômico da região e a dor e o transtorno causado aos sobreviventes e desalojados por conta do desastre (VISEU, 2008).

De acordo com uma análise estatística publicada pelo ICOLD (1995), tendo como base a análise de dados de 169 rupturas de barragens que foram coletados em uma campanha internacional para aquisição de informações sobre acidentes e incidentes com barragens, comprovou-se que, em termos absolutos, a maior parte das rupturas acontecem com pequenas barragens de terra, o que já tinha sido verificado em um estudo anterior de 1983 (VISEU, 2008).

\subsubsection{Acidentes ocorridos com pequenas barragens}

Em 15 de junho de 2020, a barragem Guilherme Pontes, situada na zona rural do município de Sairé, no Agreste Pernambucano, rompeu devido às fortes chuvas que ocorreram na região, atingindo os municípios de Sairé, Barra de Guabiraba e Côrtes que estão localizados no fluxo do rio Sirinhaém, percorrendo uma distância de mais de $50 \mathrm{~km}$. Mais de mil famílias ficaram desalojadas e as cidades foram inundadas com o grande fluxo de água. Moradores da zona rural ficaram isolados devido à destruição das estradas e acessos. Segundo informações do SNISB, o reservatório 
foi construído em terra, tem $8,0 \mathrm{~m}$ de altura e cerca de $0,35 \mathrm{hm}^{3}$ de volume e era utilizado para irrigação (ANA, 2020).

Em 2019, um acidente com grande repercussão nacional aconteceu no município de Pedro Alexandre no Nordeste da Bahia. No dia 11 de julho daquele ano, a barragem do povoado Quati, que foi construída em um dos afluentes do Rio do Peixe nos anos 2000, não aguentou o volume de água e se rompeu. A barragem, que sofreu galgamento, era de terra e tinha uma altura de 7,65 m e um volume de 0,597 $\mathrm{hm}^{3}$ (ANA, 2020). De acordo com a Defesa Civil, devido às fortes chuvas, açudes menores próximos entraram em colapso e encheram a barragem do Quati.

Cerca de 14,4 mil pessoas foram afetadas com a inundação; um trecho da adutora que fornecia água para a região foi levado pela enxurrada; a BR 235, que passa pela região, foi interditada. A região, segundo o governo do estado, tem centenas de represamentos de água, a maioria em áreas particulares, usados para abastecer casas, irrigação e dessedentação animal. Com o colapso das estruturas a montante, o volume de água, que foi muito grande, acumulou na barragem do Quati. A barragem não suportou a quantidade de água e acabou rompendo. A água seguiu o curso do Rio do Peixe, transbordou e inundou as casas que ficam à sua margem, em Pedro Alexandre e Coronel João Sá. Por se tratar de uma estrutura de pequeno porte, conforme o governo do estado, a barragem não se enquadra na PNSB e, portanto, não caberia ao governo fiscalizar. O monitoramento, como informou o governo, caberia ao município (G1, 2019).

Observa-se no Quadro 2 os acidentes ocorridos entres os 2018/2019 relatados no RSB (ANA, 2020). 
Quadro 2 - Acidentes ocorridos com barragens entre os anos 2018/2019.

\begin{tabular}{|c|c|c|c|c|}
\hline Barragem & UF & Tipo & Acidente & Causa provável \\
\hline Salgadinho & CE & $\mathrm{S} / \mathrm{l}$ & $\begin{array}{l}\text { Rompimento da barragem; sem vítimas, } \\
\text { apenas danos materiais }\end{array}$ & $\begin{array}{l}\text { Galgamento causado por fortes } \\
\text { chuvas. }\end{array}$ \\
\hline Passagem da Onça & CE & $S / l$ & $\begin{array}{l}\text { Rompimento da barragem; sem vítimas, } \\
\text { apenas danos materiais }\end{array}$ & $\begin{array}{l}\text { Galgamento causado por fortes } \\
\text { chuvas. }\end{array}$ \\
\hline Mimosos & PE & Terra & $\begin{array}{l}\text { Rompimento pelo vertedouro em } \\
\text { alvenaria }\end{array}$ & $\begin{array}{l}\text { Presença de erosões sobre a } \\
\text { crista, os taludes e encontro com } \\
\text { ombreira. }\end{array}$ \\
\hline Barragem de água de um empreendimento particular & MG & Terra & Rompimento da barragem & $\begin{array}{l}\text { Se rompeu em decorrência de não } \\
\text { suportar o elevado volume de } \\
\text { água da chuva. Constatou-se que } \\
\text { parte do maciço foi levada e que } \\
\text { houve apenas danos materiais. } \\
\text { Nenhuma vítima fatal. }\end{array}$ \\
\hline João Falqueto & ES & Terra & Rompimento da barragem & $\begin{array}{l}\text { Grande volume de chuvas que } \\
\text { ocorreu na região causando o } \\
\text { galgamento da barragem e o } \\
\text { início do processo erosivo do } \\
\text { talude de jusante que levou ao } \\
\text { rompimento do maciço. }\end{array}$ \\
\hline Sem nome & RO & $\mathrm{S} / \mathrm{I}$ & Rompimento da arragem & Sem informações. \\
\hline Malhada & TO & Terra & Rompimento do maciço de terra & $\begin{array}{l}\text { Foram identificados vários } \\
\text { problemas que podem ter } \\
\text { contribuído para o evento, tais } \\
\text { como infiltrações, erosões e } \\
\text { redução da capacidade de } \\
\text { escoamento do extravasador. }\end{array}$ \\
\hline Balneário Iracema de Mito & TO & Terra & Rompimento da Bbarragem & $\begin{array}{l}\text { Houve um sinistro no local do } \\
\text { vertedouro, então composto. Após } \\
\text { o incidente, as estruturas ficaram } \\
\text { danificadas, ocorrendo um } \\
\text { solapamento da crista e estrutura } \\
\text { do vertedouro, rompimento do } \\
\text { piso e laterais da saída do } \\
\text { vertedouro que era constituído por } \\
\text { degraus dissipadores de energia } \\
\text { do fluxo de água corrente a } \\
\text { jusante do vertedouro. }\end{array}$ \\
\hline Açude Alto Amorim & RS & $S / l$ & Rompimento da barragem & $\begin{array}{l}\text { Fortes chuvas que aconteceram } \\
\text { na região. }\end{array}$ \\
\hline
\end{tabular}

Fonte: Adaptado de ANA (2020). 


\subsection{MÉTODOS PARA IDENTIFICAÇÃO DE MASSAS D'ÁGUA POR SENSORIAMENTO REMOTO}

A ANA apresenta uma base de dados disponível gratuitamente, com as massas d'água do Brasil, que tem como objetivo gerar informações para subsidiar ações de planejamento, gestão e regulação de recursos hídricos em nível nacional e efetivar a integração de dados dos sistemas: Sistema Nacional de Informações sobre Recursos Hídricos (SNIRH), que é um dos instrumentos da PNRH; Sistema Nacional de Informações sobre Segurança de Barragens (SNISB), instrumento da PNSB; Sistema Federal de Regulação de Usos (REGLA); Sistema de Acompanhamento de Reservatórios (SAR); e do Cadastro Nacional de Usuários de Recursos Hídricos (CNARH) (ANA, 2020).

A metodologia utilizada pela ANA conta com diversas bases de dados:

- Bioma Caatinga e na região conhecida como MATOPIBA (divisa dos estados do Maranhão, Tocantins, Piauí e Bahia): Global Surface Water (GSW) que utiliza imagens Landsat;

- Biomas Mata Atlântica e Cerrado (exceto Maranhão e Piauí): mapeamento de massas d'água a partir de imagens RapidEye para o Cadastro Ambiental Rural (CAR) do Serviço Florestal Brasileiro (SFB) executado pela Fundação Brasileira para o Desenvolvimento Sustentável (FBDS);

- Bioma Pampa: utilização de imagens RapidEye na plataforma Google Earth Engine.

No caso das imagens RapidEye, foi considerado, após testes e avaliação da metodologia, um limiar de 0,5 hectares de área superficial das feições para inserção na base e, no caso das imagens Landsat, de quatro hectares. $O$ resultado deste levantamento realizado pela ANA é um quantitativo de 240.899 massas d'água, ocupando uma área superficial total de $173.749,56 \mathrm{~km}^{2}$. Do número total de massas d'água, 66.372 ou $27,6 \%$ são classificadas como de origem natural e ocupam uma área de $128.165,80 \mathrm{~km}^{2}$. As massas d'água classificadas como artificiais somam 174.527 ou $72,4 \%$ do número total de feições e ocupam uma área de $45.583,76 \mathrm{~km}^{2}$, sendo que a maioria (92\%) possui área menor ou igual a dez hectares (ANA, 2020). 
A missão Copernicus MSI/Sentinel-2, lançada em 2015 pela Agência Espacial Europeia (ESA), fornece uma excelente alternativa para estudos que necessitam de imagens de alta resolução, com muitas bandas espectrais, menos tempo de revisita e uma ampla faixa de 290 km (WANG et al., 2018). Com essas imagens é possível identificar com mais clareza as características de uso e ocupação do solo de uma determinada região, inclusive pequenas massas de água. Seu instrumento óptico coleta amostras em treze bandas espectrais: quatro bandas em $10 \mathrm{~m}$, seis bandas a $20 \mathrm{~m}$ e três bandas a $60 \mathrm{~m}$ de resolução espacial (DRUSCH et al., 2012).

O sensor MSI (Multispectral Imager) a bordo do Sentinel-2 é escolhido em diversas pesquisas científicas por seus excelente desempenho em identificar massas de água devido as suas bandas espectrais e alta resolução (Tabela 3) (DU et al., 2016; SEKERTEKIN; CICEKLI; ARSLAN, 2018; WANG et al., 2018; YANG et al., 2017; ZHANG et al., 2019). Bhangale et al. (2020) utilizou imagens do mesmo satélite para identificar reservatórios no estado de Maharashtra na Índia, os resultados da pesquisa foram utilizados por autoridades governamentais no processo de gestão dos recursos hídricos em áreas afetadas pela seca. Diante destas pesquisas e a elevada resolução das imagens foram escolhidas as imagens do Sentinel-2 para o cálculo dos índices indicadores de água.

Tabela 3 - Características das bandas espectrais do Sentinel-2.

\begin{tabular}{ccc}
\hline Bandas & Comprimento de onda $(\mu \mathrm{m})$ & Resolução $(\mathrm{m})$ \\
\hline B1 & $0,43-0,45$ & 60 \\
B2 & $0,46-0,52$ & 10 \\
B3 & $0,54-0,58$ & 10 \\
B4 & $0,65-0,68$ & 10 \\
B5 & $0,7-0,71$ & 20 \\
B6 & $0,73-0,75$ & 20 \\
B7 & $0,76-0,78$ & 20 \\
B8 & $0,78-0,90$ & 10 \\
B8 A & $0,85-0,87$ & 20 \\
B9 & $0,93-0,95$ & 60
\end{tabular}


Nesse contexto, pode-se calcular os índices de água espectral de duas bandas, que combinam duas ou mais bandas por proporções matemáticas, com melhor precisão, o que não era possível com imagens com menor resolução como no caso do Landsat. McFeeters (1996) desenvolveu um dos primeiros índices específicos para mapeamento de água, o Normalized Difference Water Index (NDWI), utilizando a banda de Infravermelho próximo (NIR) e uma banda verde. Com essa metodologia, ele conseguiu delinear águas superficiais. O NDWI é calculado de acordo com a Equação 1:

$$
N D W I=\frac{G-N I R}{G+N I R}
$$

Xu (2006) estabelece que o limite NDWI de zero não distingui com precisão superfícies construídas a partir de pixels de água e propôs outro índice o Modified Normalized Difference Water Index (NDWIm), caracterizado pela substituição da banda NIR pela SWIR. O NDWIm é calculado de acordo com a Equação 2.

$$
N D W I m=\frac{G-S W I R}{G+S W I R}
$$

Onde G é a banda green e a SWIR é a banda do infravermelho médio.

Esses índices são amplamente utilizados pela comunidade científica para identificação de corpos de água, embora sejam verificadas limitações quando se trata da identificação de pequenos corpos d'água (ZOU et al., 2018). Isso ocorre principalmente quando esses pequenos reservatórios estão envolvidos por arredores complexos como áreas urbanas ou fazendas, onde a interferência de nuvens também é mais significativa (XIE et al., 2016).

Alguns problemas são descritos na literatura em relação aos cálculos desses índices utilizando imagens do MSI/Sentinel-2. Erros de omissão podem ocorrer devido à incidência de luz solar, uma vez que o brilho pode causar uma elevada refletância em determinados ângulos de incidência solar e ângulo de visão do satélite (JACKSON, 2007). Outra limitação desses índices é conseguir discriminar água de 
sombras, asfalto, telhados e solo exposto (FEYISA et al., 2014). Os índices de água geralmente assumem ou suprimem o limite como zero, o que significa que o valor do índice maior que zero indica água e o valor de índice menor que zero indica não água (JI; ZHANG; WYLIE, 2009).

Com base nessas limitações outro método tem sido bem aceito na comunidade científica para identificação automática de corpos d'água, a conversão de cores do espaço RGB para o espaço de cores HSV formado pelas componentes hue (matiz), saturation (saturação) e value (valor). Em contrapartida ao espaço RGB padrão o HSV é melhor adaptado para segmentação de imagens, diminuindo erros como correção de nuvens finas e sombras. Essa especificidade facilitou a extração de pixels de água sobre a terra (NGOC et al., 2019).

O H (hue) é o componente angular e indica a cor em relação ao comprimento de onda; os valores podem variar entre $0^{\circ}$ e $360^{\circ}$. O componente $S$ (saturation) é determinado pela combinação da intensidade da luz e o quanto ela é distribuída em todo o espectro, descrevendo o quão branca é a cor de um objeto (um objeto branco tem um valor $S$ de 0 ). Por exemplo, um objeto verde puro é totalmente saturado, com um $S$ de 1 , enquanto tons de verde têm saturações menores que 1 . Por fim, 0 componente de valor (V) descreve a intensidade (value) da cor de um pixel considerado para uma determinada imagem. $V$ também apresenta valores entre 0 e 1 (XIAOLE et al., 2015).

Para análise estatística dos dados foi aplicado o Roon Mean Squared Error RMSE (Equação 3), que calcula a raiz quadrada média dos erros entre os valores observados e os reais. Calculou-se também o Mean Absolut Error - MAE (Equação 4 ), que calcula o erro absoluto médio entre os valores observados e os reais. Foram considerados como dados reais os valores das áreas fornecidas pela ANA.

$$
\begin{aligned}
R M S E & =\sqrt{\frac{1}{n} \sum_{j=1}^{n}\left(y_{i}-\widehat{y}_{J}\right)^{2}} \\
M A E & =\frac{1}{n} \sum_{j=1}^{n}\left|y_{i}-\widehat{y}_{j}\right|
\end{aligned}
$$




\subsection{MÉTODOS PARA ANÁLISE DE RISCO EM BARRAGENS}

\subsection{1 Índice de Priorização de Risco para Barragens proposto por Zuffo (2010)}

A metodologia foi utilizada para o desenvolvimento de um Índice de Priorização de Risco para Barragens (IPRB) (Figura 7). A determinação do índice é proposta na fase inicial da avaliação de risco.

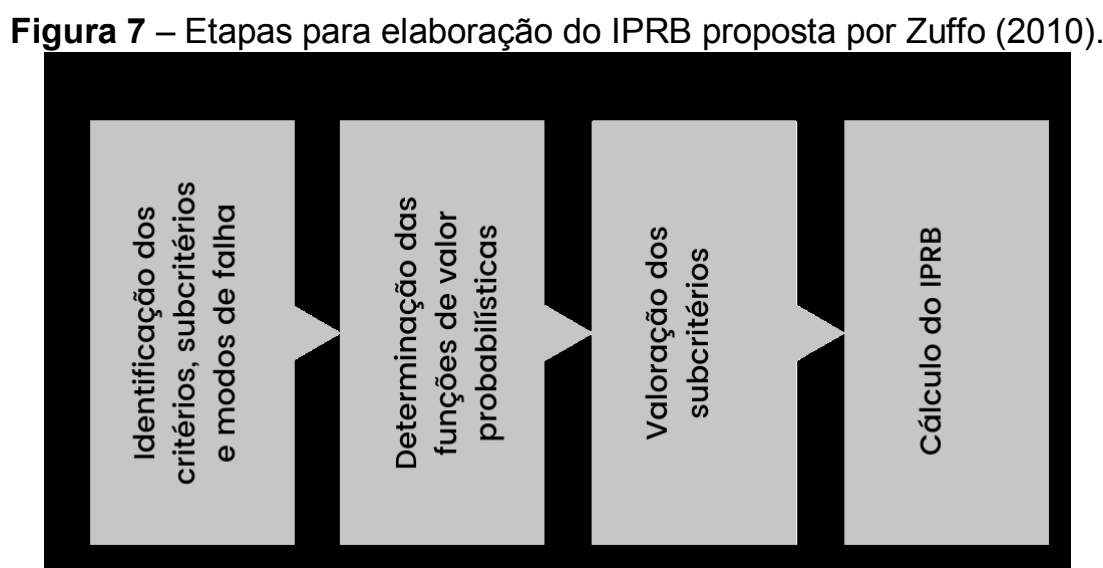

Fonte: Adaptado de Zuffo (2010).

O autor esclarece que a utilização de índices para processos de avaliação de risco permite mensurar diferentes aspectos relacionados a um possível comprometimento da estrutura da barragem. Os índices, quando bem mensurados, podem apresentar um diagnóstico global das condições de segurança da barragem. São importantes ferramentas para hierarquizar ações entre reservatórios que estão dentro de um mesmo curso d'água, bacia hidrográfica ou estudo.

A maioria das barragens construídas no mundo tem entre dez e vinte metros de altura. Entre barragens que sofreram algum tipo de falha, $34 \%$ tem altura entre onze e vinte metros; com $15 \%$ tem-se as barragens com altura entre 21 e 30 metros; e $31 \%$ das barragens com altura entre 31 e 40 metros. Barragens maiores apresentam os menores percentuais de falha, cerca de $4 \%$. Esse valor é atribuído a um processo de fiscalização mais estruturado, melhor processo de manutenção e monitoramento, regras de operação e manobra de dispositivos de controle e vertedouros melhor projetados (ZUFFO, 2005). 
Assim, conclui-se que estruturas de menor porte oferecem um risco maior para a sociedade. Vários fatores confirmam essa afirmação, como 0 fato de os empreendedores responsáveis por pequenas barragens não atenderem aos critérios técnicos construtivos mais atuais, não tem procedimentos operacionais, muitas vezes nem realizam projeto da obra e não se preocupam com processos de manutenção (ZUFFO, 2010).

A definição dos critérios e subcritérios necessários para o cálculo IPRB é baseada em dados relacionados com acidentes de barragens que aconteceram pelo mundo, cujas quantidades sejam possíveis de um tratamento estatístico adequado. Os dados foram encontrados no estudo Dam Failures - Statistical Analysis, desenvolvido pela ICOLD, em 1995. Foram selecionadas três famílias de critérios e dez subcritérios para caracterização e aplicação do IPRB, apresentados no Quadro 3. A aplicação do IPRB deve ser feita a partir de dados coletados no processo de inspeção visual da barragem (ZUFFO, 2010).

Quadro 3 - Critérios e subcritérios para avaliação do IPRB.

\begin{tabular}{|c|c|c|c|c|}
\hline Sigla & Critério & Sigla & Subcritério & Unidade \\
\hline \multirow{6}{*}{$I_{n}$} & \multirow{6}{*}{$\begin{array}{l}\text { Características } \\
\text { intrínsecas }\end{array}$} & $I_{1}$ & Altura & $\mathrm{m}$ \\
\hline & & $I_{2}$ & Volume do reservatório & $\mathrm{m}^{3}$ \\
\hline & & $I_{3}$ & Comprimento & $\mathrm{m}$ \\
\hline & & $I_{4}$ & Tipo de material & Escala semântica \\
\hline & & $I_{5}$ & Tipo de fundação & Escala semântica \\
\hline & & $I_{6}$ & Tipo de vertedor & Escala semântica \\
\hline \multirow[b]{2}{*}{$E_{n}$} & \multirow{2}{*}{$\begin{array}{l}\text { Características } \\
\text { extrínsecas }\end{array}$} & $E_{1}$ & Idade & anos \\
\hline & & $E_{2}$ & Risco sociológico & $\begin{array}{c}\text { Escala semântica e } \\
\text { numérica }\end{array}$ \\
\hline \multirow{2}{*}{$D_{n}$} & \multirow{2}{*}{$\begin{array}{l}\text { Características de } \\
\text { projeto }\end{array}$} & $D_{1}$ & $\begin{array}{c}\text { TR dos sistemas de } \\
\text { descarga }\end{array}$ & anos \\
\hline & & $D_{2}$ & Condições gerais & Escala semântica \\
\hline
\end{tabular}

Fonte: Adaptado de Zuffo (2010). 


\subsection{2 Índice de Segurança de Pequenas Barragens (ISPB) proposto por Pinto (2020)}

O objetivo proposto por Pinto (2020) é a elaboração de um Índice de Segurança de Pequenas Barragens (ISPB) para pequenas barragens de águas que não se enquadram na PNSB, a partir do índice proposto por (Zuffo (2005) e modificado por Aguiar et al. (2015), levando em consideração as características das pequenas estruturas e tornando o índice uma ferramenta de fácil utilização por parte dos órgãos gestores de recursos hídricos.

O ISPB é composto por 22 critérios (Quadro 4) baseados em escalas préexistentes na literatura e/ou conceitos verificados no processo de revisão bibliográfica. É elaborada uma matriz de classificação com base nas categorias e pesos dos 22 critérios estabelecidos, determinando o nível de segurança das barragens, facilitando o processo de vistoria das barragens e auxiliando no processo de priorização dos processos de manutenção das estruturas. Após a definição dos critérios, foram atribuídas às categorias notas de 1 a 100 , sendo que as notas mais altas representam níveis de segurança mais elevados (PINTO,2020). 
Quadro 4 - Critérios utilizados para cálculo do ISPB proposto por Pinto (2020).

\begin{tabular}{|c|c|c|c|}
\hline Sigla & Critério & Sigla & Critério \\
\hline$Q_{1}$ & Dano potencial Associado & $Q_{12}$ & Conservação das estruturas vertedoras \\
\hline $\mathrm{Q}_{2}$ & Presença de percolação os vazamentos & $Q_{13}$ & Altura da barragem \\
\hline$Q_{3}$ & $\begin{array}{l}\text { Procedimentos de inspeção de } \\
\text { segurança e monitoramento }\end{array}$ & $Q_{14}$ & Presença de deformações ou recalques \\
\hline $\mathrm{Q}_{4}$ & $\begin{array}{l}\text { Relatórios de inspeção de segurança } \\
\text { com análise e interpretação }\end{array}$ & $Q_{15}$ & $\begin{array}{l}\text { Regra operacional dos dispositivos de } \\
\text { descarga }\end{array}$ \\
\hline$Q_{5}$ & $\begin{array}{l}\text { Estrutura organizacional e qualificação } \\
\text { dos profissionais da equipe técnica de } \\
\text { segurança da barragem }\end{array}$ & $Q_{16}$ & Deterioração dos taludes \\
\hline Q6 & $\begin{array}{l}\text { Instrumentação e monitoramento dos } \\
\text { registros }\end{array}$ & $Q_{17}$ & $\begin{array}{l}\text { Barragens em série no mesmo curso } \\
\text { d'água }\end{array}$ \\
\hline$Q_{7}$ & $\begin{array}{l}\text { Existência de planos de ações } \\
\text { emergenciais }\end{array}$ & $Q_{18}$ & $\begin{array}{l}\text { Existência de infraestrutura e serviços } \\
\text { públicos }\end{array}$ \\
\hline$Q_{8}$ & Existência de documentação de projeto & $Q_{19}$ & Idade da barragem \\
\hline Q9 & $\begin{array}{l}\text { Período de retorno da vazão de projeto } \\
\text { do vertedor }\end{array}$ & $\mathrm{Q}_{20}$ & Tipo de material da barragem \\
\hline$Q_{10}$ & Vazão de projeto do vertedor & $Q_{21}$ & Evidência de erosão a jusante \\
\hline$Q_{11}$ & Volume do reservatório & $Q_{22}$ & $\begin{array}{l}\text { Conservação das estruturas de } \\
\text { captação }\end{array}$ \\
\hline
\end{tabular}

Fonte: Adaptado de Pinto (2020).

Para a análise de critérios que levam em consideração o vale a jusante da barragem, foi adotado um método simplificado para determinação da área afetada em caso de rompimento. Considerou-se uma área arbitrária a jusante do barramento com raio de $5 \mathrm{~km}$ e largura de duzentos metros, cem metros de cada lado do talvegue, para levantamento de serviços de infraestrutura, serviços públicos essenciais e o DPA (PINTO, 2020).

Um dos desafios enfrentados por Pinto (2020) é a falta de informação sobre as barragens. Os dados fornecidos pelo órgão fiscalizador não apresentavam informações que atendessem a todos os critérios definidos no estudo e, para melhores resultados, seria necessária a realização de inspeções in loco, o que não foi possível devido à pandemia, tornando ainda mais evidente a necessidade de um melhor 
acompanhamento por parte dos órgãos fiscalizadores para que os empreendedores regularizem os seus empreendimentos.

\subsubsection{Segurança dos Vales a Jusante das Barragens: Metodologias de Apoio à Gestão do Risco de acordo com Viseu (2008)}

Em seu estudo, Viseu (2008) aborda a temática da importância da análise de riscos dos vales a jusante das barragens e como é necessário que haja um esforço conjugado entre empreendedores, órgãos fiscalizadores e comunidade para que essas áreas sejam protegidas em caso de acidentes de rompimento das barragens. Também são definidos conceitos importantes como o de Dano Potencial Possível e Vulnerabilidade dessas regiões a jusante.

A Vulnerabilidade do vale a jusante é caracterizada por diversos fatores (VISEU, 2008):

- Meio físico: mostra a capacidade do meio, como casas, edifícios e estruturas urbanas, de resistir aos impactos ocasionados pela onda de cheia;

- Social: que é caracterizado pela capacidade de sobrevivência e recuperação da população atingida;

- Econômica: caracterizada pela capacidade econômica da região de se recuperar após o acidente;

- Agente de proteção civil: capacidade desses agentes de antecipação, ação e recuperação do acidente, ou seja, como são estabelecidas as práticas de planejamento em situações de emergência.

O estudo enfatiza a necessidade da caracterização da ocupação do vale a jusante, com informações sobre densidade populacional, realizando uma estimativa do número de pessoas efetivamente expostas e um levantamento das consequências ambientais e econômicas em caso de acidentes. 


\section{METODOLOGIA}

Os procedimentos adotados na pesquisa foram desenvolvidos através da análise de trabalhos científicos, com a aplicação de ferramentas e métodos descritos na literatura, os quais foram consolidados e aprimorados durante o desenvolvimento do trabalho. A técnica dissertada a seguir, de forma coesa e objetiva, descreve os processos adotados que levaram ao atendimento dos objetivos propostos. Observase na Figura 8 o fluxo metodológico proposto na pesquisa.

Figura 8 - Fluxo metodológico proposto.

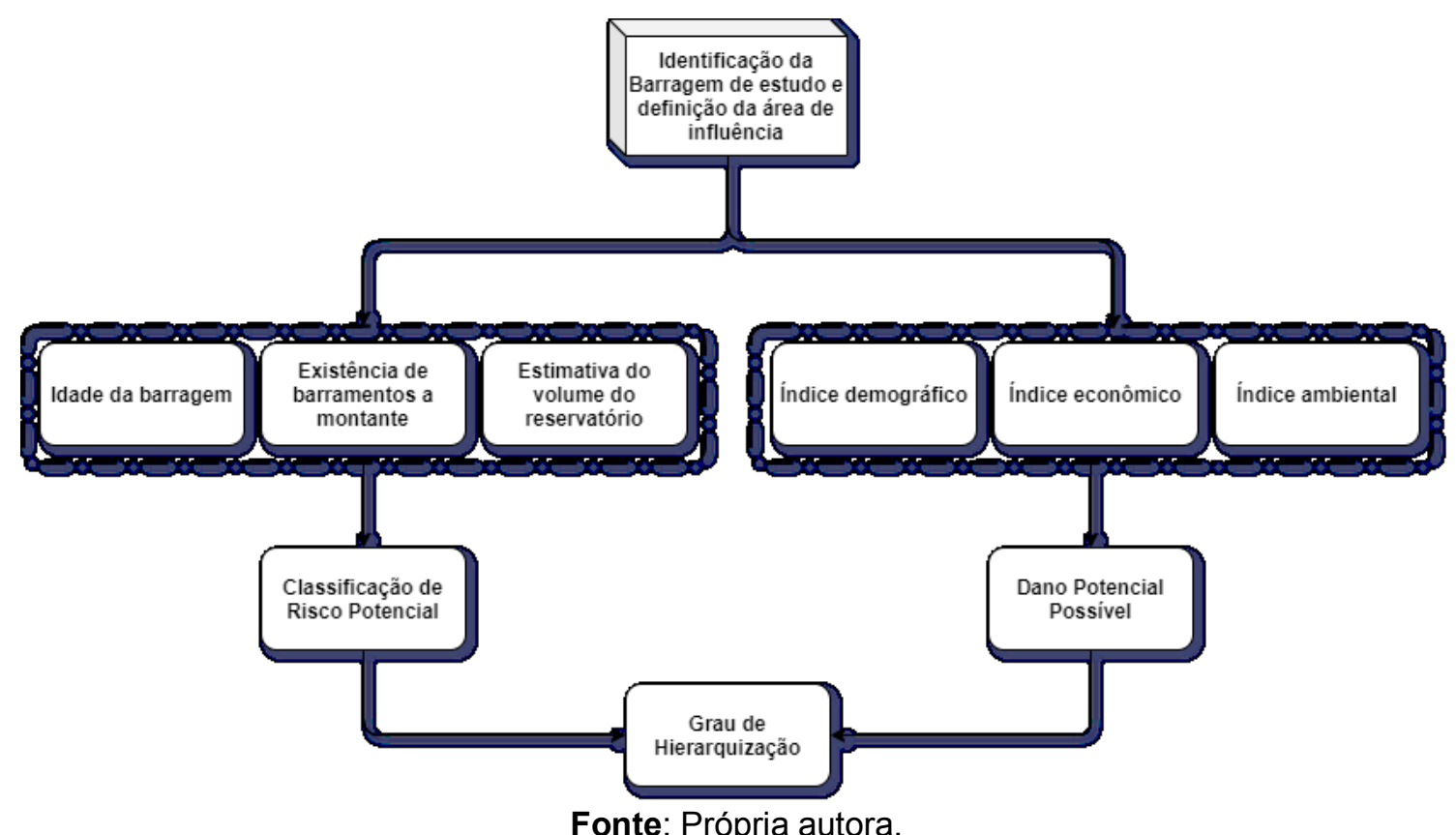

\subsection{CARACTERIZAÇÃO DA ÁREA DE ESTUDO}

O município de Sumé está localizado no estado da Paraíba (Figura 9), na microrregião do Cariri Ocidental e na mesorregião da Borborema. Em termos geográficos possui uma área de $833,315 \mathrm{~km}^{2}$, situando-se em uma altitude de $533 \mathrm{~m}$, com temperatura média anual de $25^{\circ}$. Segundo dados do IBGE (2020), sua população está estimada em 17,031 habitantes e uma densidade demográfica de 19,16 hab/km². De acordo com o Censo Agropecuário 2017, Sumé tem 905 estabelecimentos agropecuários, ocupando uma área de 48.581 hectares, e eles utilizam a terra para 
fins de lavouras, permanentes e temporárias, pastagens, sistemas agroflorestais. Desse número, 243 apresentam área irrigada (IBGE, 2019).

Figura 9 - Mapa de localização de Sumé.

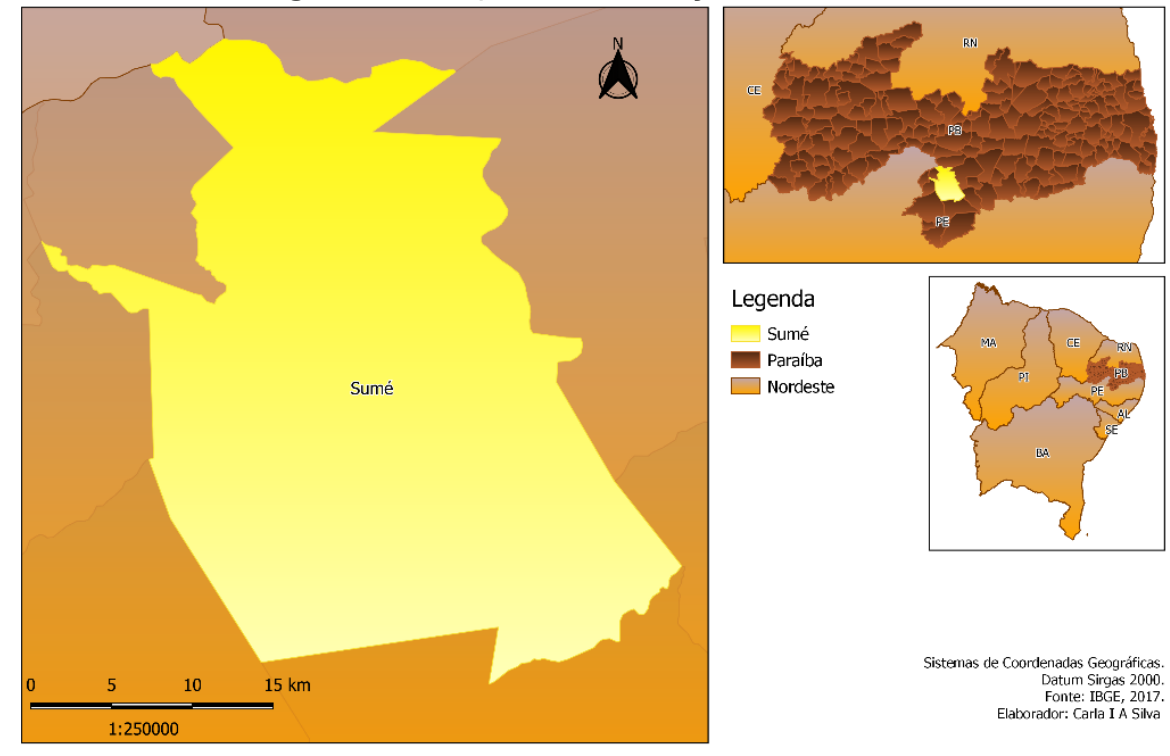

Fonte: Própria autora.

\subsection{AQUISIÇÃO E PROCESSAMENTO DAS IMAGENS}

\subsubsection{Escolha das Imagens de Satélite}

Para identificação das massas d'água foram utilizados como base os dados da ANA (2019), esses dados fazem parte da Base Hidrográfica Ottocodificada (BHO) disponibilizada pela agência que contém as massas d'água existentes no território nacional, tais como lagos, lagoas, açudes, represas, reservatórios (naturais e artificiais) e trechos de rios representados como linhas e polígonos. Com a finalidade de identificar pequenas barragens outros métodos, que utilizam imagens de satélite, descritos na literatura, foram utilizados na pesquisa e os resultados foram comparados com a base da ANA, com o objetivo de selecionar uma metodologia simplificada que melhor defina o objeto de estudo.

Através de imagens de satélite é possível identificar a capacidade de armazenamento máxima de reservatórios e avaliar as mudanças nos níveis de água ao longo de um determinado período de interesse (SAWUNYAMA; SENZANJE; 
MHIZHA, 2006). Para escolha do hiato temporal de análise, foram examinados dados fornecidos pela Agência Executiva de Gestão das Águas do Estado da Paraíba (AESA) do índice pluviométrico anual de 2015 a 2020, para o município de Sumé. O ano de 2020 apresentou os maiores níveis de precipitação, para o período analisado como observa-se na Tabela 4. Desta forma, é possível avaliar a capacidade destes corpos hídricos e obter imagens de melhor qualidade.

Tabela 4 - Precipitação anual acumulada para o município de Sumé de 2015 - 2020.

\begin{tabular}{cc}
\hline Ano & Precipitação $(\mathrm{mm})$ \\
\hline 2015 & 220,4 \\
2016 & 285,3 \\
2017 & 237,4 \\
2018 & 405,8 \\
2019 & 545,4 \\
2020 & 747,0
\end{tabular}

Fonte: Adaptado de Paraíba (2021).

\subsubsection{Obtenção e Processamento das Imagens}

As imagens do Sentinel-2 foram obtidas e processadas através da plataforma Google Earth Engine (GEE) para o ano de 2020, de forma gratuita e utilizando o processamento em "nuvem". Foram realizadas análises no que se refere a presença de nuvens nas imagens, pois as mesmas geram ruídos nas imagens que podem interferir significativamente nos resultados.

Segundo Molle (1994), a avaliação do volume de reservatórios a partir da superfície do espelho d'água só é possível logo após uma estação chuvosa muito abundante. Deste modo, para um melhor resultado da identificação desses reservatórios seria ideal a análise logo após o período chuvoso, porém não foi possível analisar as imagens em um hiato de apenas quatro meses, pois as imagens apresentavam muitas nuvens. O regime pluviométrico do ano de 2020 está ilustrado na Figura 10. Foram utilizados filtros para remoção de nuvens, imagens com percentual acima de $20 \%$ de nuvens foram excluídas. Após a seleção das imagens 
para período selecionados, foram utilizadas as bandas B4, B3 e B2 para composição da imagem RGB para posterior verificação visual das massas de água.

Figura 10 - Regime pluviométrico do município de Sumé - Ano 2020.

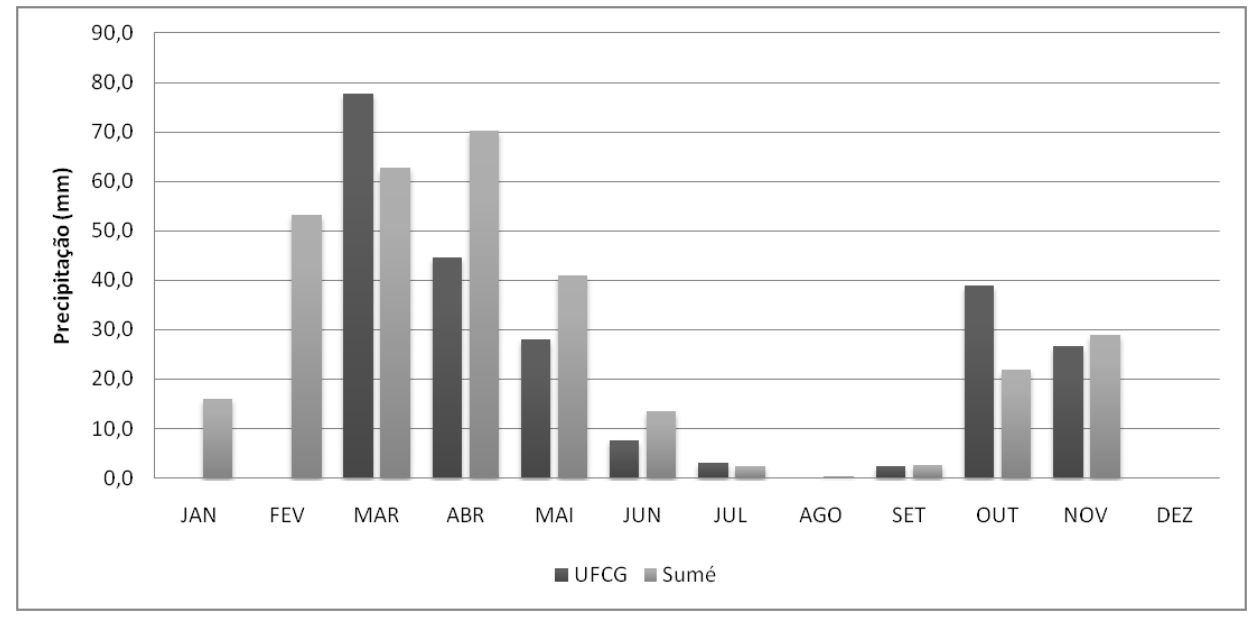

Fonte: Paraíba (2021).

\subsection{CLASSIFICAÇÃO DAS IMAGENS E EXTRAÇÃO DOS ESPELHOS D'ÁGUA}

Para identificação e classificação das massas d'água foram utilizadas técnicas de sensoriamento remoto levantadas ao longo da fundamentação teórica, descrita no capítulo 2. Essas metodologias foram viáveis ao presente estudo, enfatizando a importância da utilização de ferramentas de baixo custo e fácil acesso para o processo de gestão dos recursos hídricos.

\subsubsection{Cálculo do NDWI e NDWIm}

Diferentes técnicas de extração de reservatórios são utilizadas em sensoriamento remoto, para o cálculo dos índices espectrais da água foram utilizadas as bandas:

- Para o NDWI, foram utilizadas as bandas B3 (green) e B8 (NIR);

- Para o NDWIm foram utilizadas as bandas B3 (green) e B11 (SWIR).

Na plataforma GEE a operação de normalização de duas bandas espectrais pode ser realizada pela aplicação da função normalizedDifference. Após o cálculos dos índices espectrais foi aplicada uma camada de máscara, com o auxílio do 
algoritmo updateMask, para um limite inferior de 0 e superior de 1, conforme escala estabelecida por McFeeters (1996) e Xu (2006) que definem como água NDWI e NDWIm $\geq 0$. Os produtos desta etapa foram exportados do GEE, no formato raster, e importados para o software QGIS 3.10. As superfícies de interesse foram isoladas com o auxílio do algoritmo Binarization Threshold e depois aplicando a ferramenta raster para vetor (poligonizar) foram gerados os polígonos dos corpos hídricos e adicionou-se aos seus atributos um número de identificação para cada superfície e a componente área em ha.

\subsubsection{Transformação RGB para HSV}

As massas de água extraídas através da composição HSV também foram calculadas no GEE através do algoritmo rgbToHsv. Após a identificação das massas de água, os dados gerados foram exportados do GEE em formato raster e importados para o software QGIS versão 3.10 e foram vetorizados. As superfícies de interesse foram isoladas com o auxílio do algoritmo Binarization Threshold e depois aplicando a ferramenta raster para vetor (poligonizar) foram gerados os polígonos dos corpos hídricos e adicionou-se aos seus atributos um número de identificação para cada superfície e a componente área em ha.

\subsubsection{Avaliação da Extração dos Espelhos d’água}

Para avaliar a qualidade da extração das massas d'água e se os polígonos gerados condizem com os reservatórios da região foi realizada a análise visual das imagens e a comparação dos dados fornecidos pela ANA. Os polígonos foram sobrepostos e foi analisada correspondência geográfica entre os polígonos extraídos através da metodologia e os fornecidos pela ANA. Um fator limitante da extração dos corpos d'água por ferramentas de sensoriamento remoto é a presença de constituintes orgânicos, como clorofila a, e inorgânicos, como minerais e material em suspensão na água (FLORES, 2019). Esse fato pode contribuir com uma menor absorção de luz pelo corpo hídrico e dificultar o processo de identificação, sendo uma fonte de erros mais significativos para reservatório com área menor que 1ha. Devido a este 
comportamento, os polígonos com área menor que um hectare foram excluídos deste procedimento. Como o objeto de estudo desta pesquisa são pequenas barragens, foi estabelecido um limite superior de área para os polígonos, sendo excluídos polígonos com áreas superiores a vinte hectares. Em síntese objetos com áreas menores que um hectare e maiores que vinte hectares foram desconsiderados nesta pesquisa.

Outra etapa da classificação foi a seleção de polígonos que cruzavam com a rede de drenagem. Para o cálculo da rede de drenagem foram utilizados dados digitais de elevação da Shuttle Radar Topography Mission - SRTM, fornecido pela NSA JPL, em escala global, hidrologicamente consistente, com resolução de 1 arco de segundo (aproximadamente $30 \mathrm{~m}$ ) exportados pelo GEE (FARR et al., 2007). Para o cálculo da rede de drenagem foi utilizado o plugin IPH-Hydro Tools, que é uma ferramenta desenvolvida pelo grupo Hidrologia de Grande Escala - HGE da Universidade Federal do Rio Grande do Sul - UFRGS, ele permite ao usuário extrair atributos como rede de drenagem, bacias e microbacias hidrográficas a partir de modelos digitais de elevação (SIQUEIRA, et al., 2016).

Após a identificação das barragens, foi escolhida de forma aleatória uma barragem para aplicação da metodologia proposta. Foi realizada a delimitação de uma área de influência de $5 \mathrm{~km}$ de comprimento e 200 metros de largura a jusante da barragem seguindo o curso do rio, para que possa ser feito o levantamento do Dano Potencial Possível associado à região baseado nos critérios propostos e o cálculo do Grau de Hierarquização.

\subsection{DEFINIÇÃO DE CRITÉRIOS E MATRIZ DE HIERARQUIZAÇÃO}

Os critérios foram definidos com o objetivo de promover uma análise preliminar de forma simples e conservadora, apresentando um cenário aproximado das possíveis consequências em caso de acidente. Essa abordagem evita que estudos muito caros e detalhados sejam realizados sem necessidade para classificar pequenas barragens ou estruturas com consequências obviamente mais baixas.

Destarte, as zonas de inundação têm que ser claramente definidas com parâmetros como área, vazão de pico, profundidade da cheia e velocidade da água para que se possa definir os danos em caso de acidentes que geram uma onda de 
inundação. No entanto, os custos associados a estudos hidrológicos, de ruptura de barragens e definição das rotas da água a jusante são uniformemente citados nos EUA e em outros países com programas complexos e o principal impedimento para elaboração dos PAEs. Outro fator impeditivo é a falta de informações topográficas consistentes para realização dessas análises, essenciais para os estudos (ANA, 2014). Diante desse cenário de complexidade que envolve o tema, os critérios definidos neste estudo devem ser avaliados e as ponderações podem ser atribuídas em cada parâmetro apresentados na sequência.

\subsubsection{Critérios Estruturais Relacionados à Barragem (CE)}

Os Critérios Estruturais (CE) são características associadas ao projeto original da barragem. Consoante os critérios estabelecidos pelo $\mathrm{CNRH}$, seis características técnicas devem ser avaliadas para a classificação quanto à Categoria de Risco - CRI: altura, comprimento, tipo, fundação, idade e vazão de projeto. Para avaliação da maioria dessas características, é necessária a análise do projeto construtivo e visita in loco. Deve-se considerar também que muitas estruturas não apresentam seus projetos construtivos e que o objetivo da pesquisa é identificar variáveis que possam ser analisadas por imagens de satélite, por isso, serão adotados como CE para definição do Grau de Hierarquização as características relacionadas à idade da barragem apresentadas na Tabela 5 .

Tabela 5 - Critério relacionado à idade da barragem $\left(\mathrm{CE}_{1}\right)$.

\begin{tabular}{cc}
\hline Classe & Definição \\
\hline 1 & Entre 30 e 50 anos \\
2 & Entre 10 e 30 anos \\
3 & Entre 5 e 10 anos \\
4 & $<$ que 5 anos ou > 50 anos ou \\
sem informação
\end{tabular}

Fonte: Adaptado de Brasil (2012a).

Para identificação da idade da barragem será utilizada a coleção Monthly Water History que faz parte do conjunto de dados Joint Research Centre's Global Surface 
Water Dataset, que é um mapeamento global de alta resolução das águas superficiais e suas mudanças ao longo do tempo. A coleção Monthly Water History fornece informações sobre todas as detecções de massas d'água mensais, entre os anos 1984 e 2019. O objetivo é identificar eventos específicos, por exemplo, para ver quando uma barragem foi construída em um determinado local (PEKEL et al., 2016). O conjunto de dados históricos estão disponíveis no GEE como uma coleção de imagens, cada imagem possui metadados que indicam o mês e o ano da imagem e a ocorrência de água é identificada de acordo com os valores de 0 a 2 (Tabela 6).

Tabela 6 - Escala dos dados fornecidos pela coleção Monthly Water Hic
\begin{tabular}{ll} 
Valor & Descrição \\
\hline 0 & Não observado \\
1 & Não água \\
2 & Água \\
\hline
\end{tabular}

Fonte: Adaptado de Pekel et al. (2016).

- Existência de barramentos a montante

A existência de barragens a montante do reservatório em análise foi feita de forma visual, através de imagens de satélite, conforme classificação apresentada na Tabela 7.

Tabela 7 - Classificação da existência de barramentos a montante da barragem (CE2).

\begin{tabular}{cl}
\hline Classe & \multicolumn{1}{c}{ Definição } \\
\hline 0 & Não existem barramentos a montante \\
1 & Inexistência de barramentos a montante a uma distância de $5 \mathrm{~km}$ \\
2 & Existência de 1 ou 2 barramentos a montante a uma distância de $5 \mathrm{~km}$ \\
3 & Existência de 2 ou 3 barramentos a montante a uma distância de $5 \mathrm{~km}$ \\
4 & Existência de 3 ou mais barramentos a uma distância de $5 \mathrm{~km}$ \\
\hline
\end{tabular}

Fonte: Adaptado de Leite (2019). 
- Volume total do reservatório $\left(\mathrm{CE}_{3}\right)$

Para uma estimativa do volume do reservatório foram adotadas as equações proposta por Molle (1994) que estabelece uma estimativa do volume do reservatório a partir da superfície observada por imagens de satélite. As equações do Molle (1994) foram utilizadas por Santos (2009) para estimativa do volume de pequenos açudes na bacia hidrográfica do açude de Sumé. Para açudes com área inferior a vinte hectares, foi encontrada uma correlação entre volume, declividade média do riacho e área do reservatório, essa relação é expressa pela Equação 5.

$$
V_{x}=0,117 S_{x}^{1,263} D M^{0,49} \quad R^{2}=0,905 \quad S_{x}<20 h a
$$

Outra forma também descrita por Molle (1994) aborda a caracterização de pequenos açudes através de três parâmetros simples: volume $(V)$, profundidade $(H)$ e a área da superfície (S). A relação entre o volume $(\mathrm{V})$, a área da superfície (S) e a profundidade $(\mathrm{H})$ de um reservatório pode ser obtida com o uso dos coeficientes de forma $\alpha$ e $K$. Os coeficientes irão variar de acorco com a topografia da bacia hidráulica analisada. A correspondência entre os parâmetros $\mathrm{H}, \mathrm{S}$ e $\mathrm{V}$ e os coeficientes de forma, podem ser observados nas Equações 6, 7 e 8.

$$
\begin{gathered}
V=K \times H^{\alpha} \\
S=\alpha \times K \times H^{(\alpha-1)} \\
V=\frac{H \times S}{\alpha}
\end{gathered}
$$

Para a região do semiárido, Molle (1994) realizou um estudo com 420 pequenos açudes, estabelecendo inúmeras correlações entre eles. Como um dos resultados obtidos na pesquisa, podemos enfatizar a definição do valor médio de $\alpha=2,70$ para pequenos açudes na região semiárida, tornando assim possível estabelecer uma relação direta entre volume, área de superfície e a profundidade máxima de pequenos açudes. A classificação quanto ao volume está apresentada na Tabela 8. 
Tabela 8 - Classificação de acordo com o volume do reservatório $\left(C E_{3}\right)$.

\begin{tabular}{cc}
\hline Classe & Definição \\
\hline 1 & Até $1 \mathrm{hm}^{3}$ \\
2 & Entre 1 e $3 \mathrm{hm}^{3}$ \\
3 & Entre 3 e $5 \mathrm{hm}^{3}$ \\
4 & $>5 \mathrm{hm}^{3}$ \\
\hline
\end{tabular}

Fonte: Própria autora.

A Classificação de Risco Potencial (CRP) será dada pela média simples dos três critérios estruturais (Equação 9), e a classificação será feita conforme a Tabela 9.

$$
C R P=\frac{C E_{1}+C E_{2}+C E_{3}}{3}
$$

Tabela 9 - Classificação de risco potencial.

\begin{tabular}{ccc}
\hline Classes $-\mathbf{C R}$ & Limites das Classes & Descrição \\
\hline 1 & $1-1,5$ & Baixo \\
2 & $1,51-2,5$ & Médio \\
3 & $2,51-3,5$ & Alto \\
4 & $3,51-4,0$ & Muito Alto \\
\hline
\end{tabular}

Fonte: Própria autora.

\subsubsection{Critérios para caracterização do vale a jusante}

Para uma análise mais acurada do vale a jusante da barragem, é necessária a definição de uma área de influência baseada em estudos de simulação de cheia e rompimento de barragem. Como o objetivo da pesquisa é propor uma metodologia simplificada de análise da área de influência, esta área será definida como valor fixo, de $5 \mathrm{~km}$ a partir da identificação do barramento seguindo o curso da drenagem e a topografia.

O tipo de ocupação presente nas áreas de influência está diretamente relacionado ao volume de perdas de vidas humanas e danos ambientais e econômicos. Para definir as características de ocupação do solo devem ser feitas as seguintes análises: 
- Estimativa do número de residências fixas que se encontram no limite da área de influência;

- Estimativa da infraestrutura urbana que será afetada, como, por exemplo, estradas, hospitais, escolas, redes de água e esgoto, torres de energia, etc.;

- Identificação de áreas agrícolas, florestais, reservas naturais e áreas de proteção ambiental.

Com base nessa identificação e caracterização da ocupação do solo do vale a jusante da barragem, é possível estimar, de forma qualitativa, as consequências em termos de perdas de vidas humanas, prejuízos econômicos e danos ambientais. Além disso, a análise do vale a jusante será realizada utilizando a metodologia adaptada proposta por Viseu (2008), que traz a ideia de um Índice de Risco Associado (IRA) baseado em três indicadores:

- Indicador demográfico;

- Indicador de desenvolvimento econômico;

- Indicador de danos ambientais.

O IRA traduz o impacto potencial provocado por uma possível onda de cheia e é obtido através da combinação de três indicadores e seus respectivos pesos $\left(\mathrm{K}_{\mathrm{i}}\right)$ (Equação 10), que representam sua escala de importância, de modo que é possível caracterizar de forma simples o risco potencial associado:

$$
I R A=K_{1} I_{\text {dem }}+K_{2} I_{\text {eco }}+K_{3} I_{\text {amb }}
$$

Sendo: $K_{1}+K_{2}+K_{3}=1$

O Indicador de risco demográfico $\left(I_{d e m}\right)$ é a estimativa do número total de pessoas expostas e em potencial risco ou exposição na área de influência delimitada. O $I_{\text {dem }}$ é classificado de acordo com a quantidade de pessoas expostas. Essa estimativa pode ser feita considerando a densidade populacional na área em análise. $\mathrm{Na}$ Tabela 10 é listada a classificação que deve ser considerada na aplicação da metodologia. 
Tabela 10 - Classificação do indicador demográfico.

\begin{tabular}{cc}
\hline $\boldsymbol{I}_{\boldsymbol{d e m}}$ & Quantidade de pessoas expostas \\
\hline 0 & 0 \\
1 & $1-9$ \\
2 & $10-19$ \\
3 & $20-99$ \\
4 & $>100$ \\
\hline
\end{tabular}

Fonte: Adaptado de Viseu (2008).

O Indicador econômico $\left(I_{\text {eco }}\right)$ é a estimativa de áreas agrícolas, atividades industriais e a importância da infraestrutura essencial afetada pelo impacto causado pela cheia. É composto por três variáveis:

- $X_{a g r}=0$ valor de área utilizada para agricultura em hectares, traduzindo o potencial agrícola da região;

- $X_{\text {ind }}=$ o número de unidades industriais, representando o desenvolvimento industrial da área;

- $X_{\text {inf }}=$ a importância da infraestrutura urbana que será afetada em caso de acidente.

Para os aspectos de infraestrutura urbana devem ser considerados a própria barragem acidentada, rodovias, ferrovias, pontes, redes de água, esgoto, sistemas de drenagem, escolas, hospitais, redes de distribuição de energia elétrica e redes de telecomunicações.

O $I_{\text {eco }}$ será calculado através da média aritmética simples do valor numérico da classe de risco atribuída para cada uma das três variáveis consideradas no estudo (Equação 11). Na Tabela 11 é relacionada a classificação definida para o $I_{e c o}$.

$$
I_{\text {eco }}=\frac{X_{a g r}+X_{\text {ind }}+X_{\text {inf }}}{3}
$$


Tabela 11 - Classificação do indicador econômico.

\begin{tabular}{|c|c|c|c|c|c|}
\hline \multicolumn{6}{|c|}{ Indicador econômico - $I_{e c o}$} \\
\hline $\begin{array}{c}X_{a g r} \\
\text { Classe }\end{array}$ & Área Agrícola (ha) & $\begin{array}{c}X_{\text {ind }} \\
\text { Classe }\end{array}$ & $\begin{array}{l}\mathbf{N}^{\circ} \text { de unidades } \\
\text { industriais }\end{array}$ & $\begin{array}{c}X_{i n f} \\
\text { Classe }\end{array}$ & $\begin{array}{l}\text { Importância das } \\
\text { infraestruturas } \\
\text { afetadas }\end{array}$ \\
\hline 0 & Área $\leq 500$ & 0 & 0 unidades & 0 & $\begin{array}{l}\text { Sem estruturas } \\
\text { afetadas }\end{array}$ \\
\hline 1 & $500<$ Área $\leq 2000$ & 1 & Menos de 5 unidades & 1 & Importância baixa \\
\hline 2 & $2000<$ Área $\leq 4000$ & 2 & $6-10$ unidades & 2 & Importância média \\
\hline 3 & $4000<$ Área $\leq 15000$ & 3 & 11 - 50unidades & 3 & Importante \\
\hline 4 & Área > 15000 & 4 & Mais de 50 unidades & 4 & Muito importante \\
\hline
\end{tabular}

Fonte: Adaptado de Viseu (2008).

O Indicador ambiental $\left(I_{a m b}\right)$ é caracterizado pela estimativa da importância dos recursos naturais na área de influência. Observa-se na Tabela 12 a classificação dos recursos naturais da região.

Tabela 12 - Classificação dos recursos naturais.

\begin{tabular}{cc}
\hline $\boldsymbol{I}_{\boldsymbol{a m b} \boldsymbol{b}}$ & Importância dos recursos naturais \\
\hline 0 & Não existem recursos naturais \\
1 & $\begin{array}{c}\text { Recursos pouco importantes } \\
\text { Recursos importantes que sofrem } \\
\text { impacto no curto prazo, mas se } \\
\text { autorregulam no médio e longo prazo } \\
2\end{array}$ \\
$\begin{array}{c}\text { Recursos importantes que sofrem } \\
\text { impacto e se recupera apenas com } \\
\text { intervenção humana }\end{array}$ \\
4 & $\begin{array}{c}\text { Recursos importantes que sofrem } \\
\text { impactos graves e irreversíveis }\end{array}$ \\
\hline
\end{tabular}

Fonte: Adaptado de Viseu (2008).

O sistema proposto se baseia na atribuição de valores de 0 a 4 para cada um dos indicadores. Após a classificação dos indicadores é possível estimar o IRA, conforme a Tabela 13, com uma classe de hierarquização do risco potencial, entre 0 (risco muito baixo) e 4 (risco muito alto). 
Tabela 13 - Classificação IRA.

\begin{tabular}{ccc}
\hline Classes - IRA & Limites das Classes & Descrição \\
\hline 0 & $0-0,8$ & Muito baixo \\
1 & $0,81-1,60$ & Baixo \\
2 & $1,61-2,4$ & Médio \\
3 & $2,41-3,2$ & Alto \\
4 & $3,21-4,0$ & Muito Alto \\
\hline
\end{tabular}

Fonte: Adaptado de Viseu (2008).

$\mathrm{O}$ valor de $\mathrm{K}$ é uma questão subjetiva, definida pelo analista. A regra mais coerente é sempre atribuir o maior peso à parcela relativa da população (VISEU, 2008).

Assim, para Viseu (2008), é possível elaborar uma escala de cinco classes de risco e definir para cada uma delas seus limites de classificação. A hierarquização é baseada no Dano Potencial Possível que é aquele identificado como tendo a possibilidade de virar um dano potencial, mas é preciso fazer estudos e/ou análises no campo para confirmá-lo. Possíveis danos potenciais são identificados a partir de mapas topográficos, fotografias, levantamentos de campo e informações dos moradores locais. Deve-se incluir qualquer situação suspeita de ter o potencial para colocar vidas em perigo ou causar perdas econômicas devido a uma ruptura de barragem (VISEU, 2008).

\subsection{MATRIZ DE HIERARQUIZAÇÃO}

A hierarquização de ações é um poderoso instrumento utilizado no planejamento estratégico, principalmente quando se fala em um sistema deficitário de especialistas em quantidade e qualidade, bem como a escassez de recursos financeiros e técnicos. O objetivo é que, por meio da metodologia proposta, seja possível identificar barragens que precisam de ações imediatas e barragens que possam ser avaliados em momentos mais oportunos.

Com a conclusão da classificação quanto ao IRA e o CRP, utilizando-se a Matriz de Hierarquização conforme o Quadro 5, é possível estabelecer o grau de 
hierarquização (Quadro 6) para barragem analisada. Após a classificação com a utilização da matriz, serão definidos os prazos para as ações de fiscalização dos órgãos responsáveis, considerando a programação para o ciclo de um ano de planejamento.

Quadro 5 - Matriz de Hierarquização.

\begin{tabular}{|c|c|c|c|c|c|}
\hline CRP & Muito baixo & Baixo & Médio & Alto & Muito Alto \\
\hline $\begin{array}{l}\text { Muito } \\
\text { Baixo }\end{array}$ & & & & & \\
\hline Baixo & & & & & \\
\hline Médio & & & & & \\
\hline Alto & & & & & \\
\hline $\begin{array}{l}\text { Muito } \\
\text { Alto }\end{array}$ & & & & & \\
\hline
\end{tabular}

Fonte: Própria autora.

Quadro 6 - Grau de Hierarquização.

\begin{tabular}{|l|l|}
\hline Grau de Hierarquização & Descrição \\
\hline Imediato & Primeiro Trimestre \\
\hline Curto prazo & Segundo trimestre \\
\hline Médio prazo & Segundo Semestre \\
\hline Longo prazo & Próximo Ano \\
\hline
\end{tabular}

Fonte: Própria autora. 


\section{RESULTADOS E DISCUSSÃO}

\subsection{CENÁRIO PARAIBANO}

Foram identificadas 3.383 massas de águas na Paraíba, sendo 124 classificadas como de origem natural e as demais, o que equivale que $96,3 \%$ são de origem artificial, barragens em potencial. A distribuição estadual das massas de água naturais, artificiais e barragens cadastradas no SNISB estão ilustradas na Figura 11. Segundo o relatório RSB (ANA, 2020), estão cadastradas 609 barragens no estado, apenas $18,69 \%$ das massas de água identificadas pela ANA. Os municípios com maior número de barragens registradas no SNISB são: Sapé (14 barramentos), Santa Rita (15 barramentos) e Belém de Brejo do Cruz (23 barragens). Do total de barragens cadastradas, $59 \%$ são submetidas à PNSB e $34 \%$ não têm informações suficientes que indiquem se as estruturas se submetem ou não à PNSB.

Figura 11 - Distribuição espacial das massas de águas e barragens cadastradas no SNISB para o estado da Paraíba.

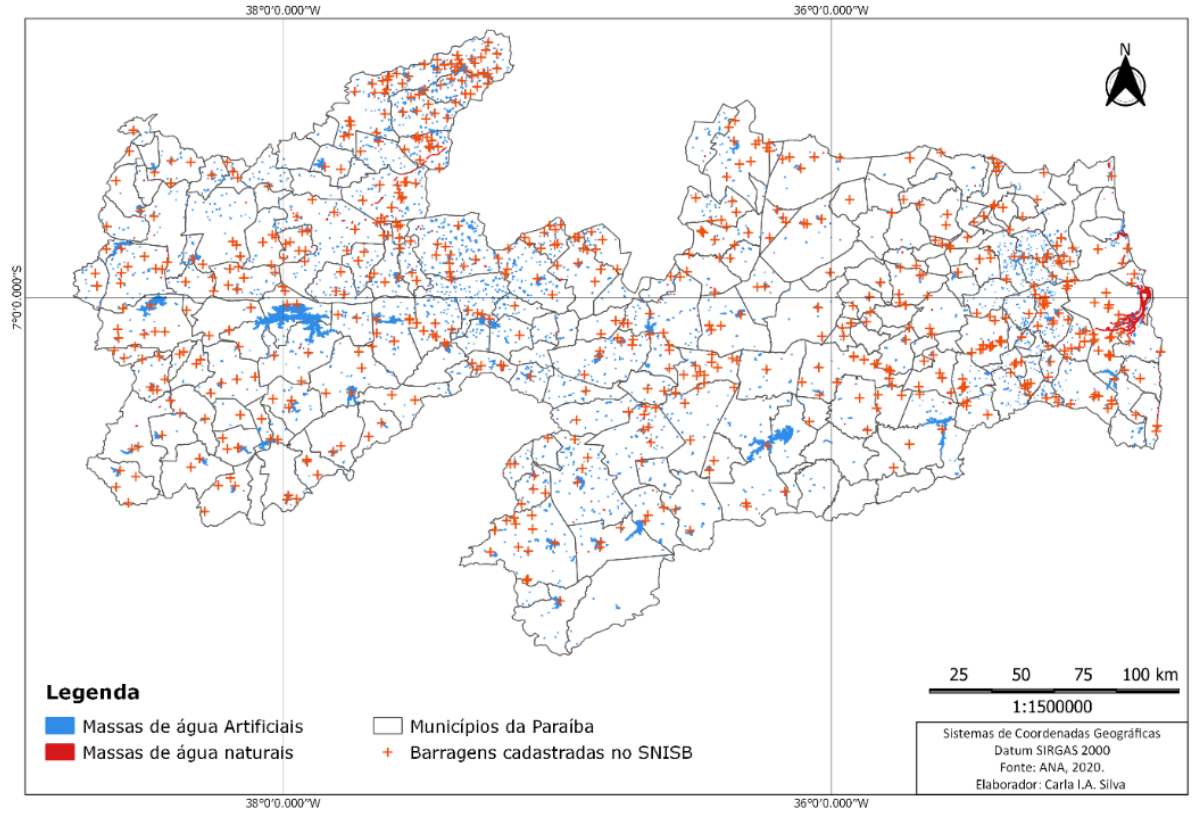

Fonte: Própria autora.

A respeito do material de construção das barragens, $51 \%$ são barragens de terra e $49 \%$ não apresentam essa informação. Em relação ao volume, apenas $32,84 \%$ 
das barragens apresentam essa informação, destas $74,87 \%$ apresentam volume inferior a $5 \mathrm{hm}^{3}$ sendo classificadas como pequenas barragens segundo o $\mathrm{CNRH}$. No tocante à altura, $51 \%$ das barragens estão abaixo de 15 metros e $32 \%$ não têm informação sobre a altura. Observa-se na Figura 12 um gráfico comparativo entre as massas de água definidas pela ANA e as barragens cadastradas no SNISB, enquanto na Figura 13 são elencados os usos prioritários das barragens na Paraíba.

Figura 12 - Quantidade de barragens cadastradas no SNISB e massas de água mapeadas pela ANA por Mesorregião na Paraíba.

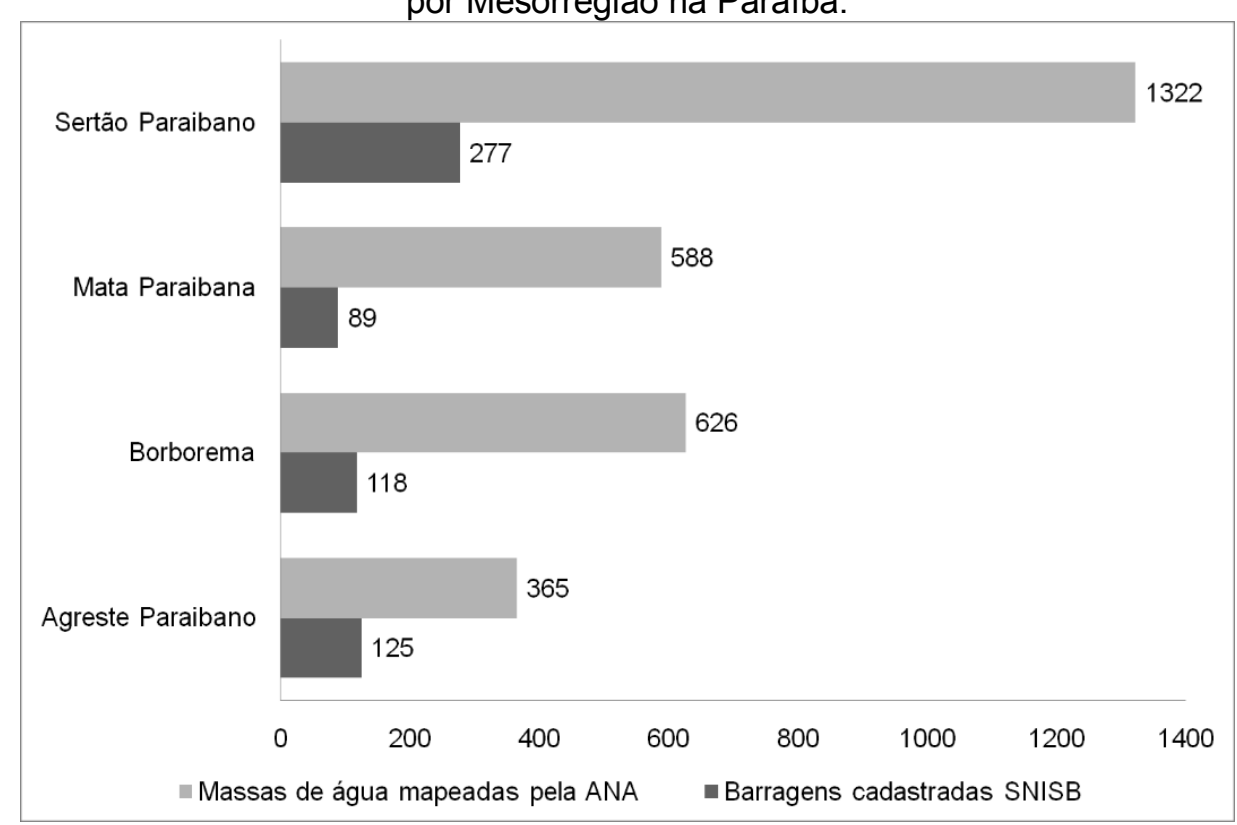

Fonte: Própria autora.

Figura 13 - Usos prioritários das barragens no estado da Paraíba.

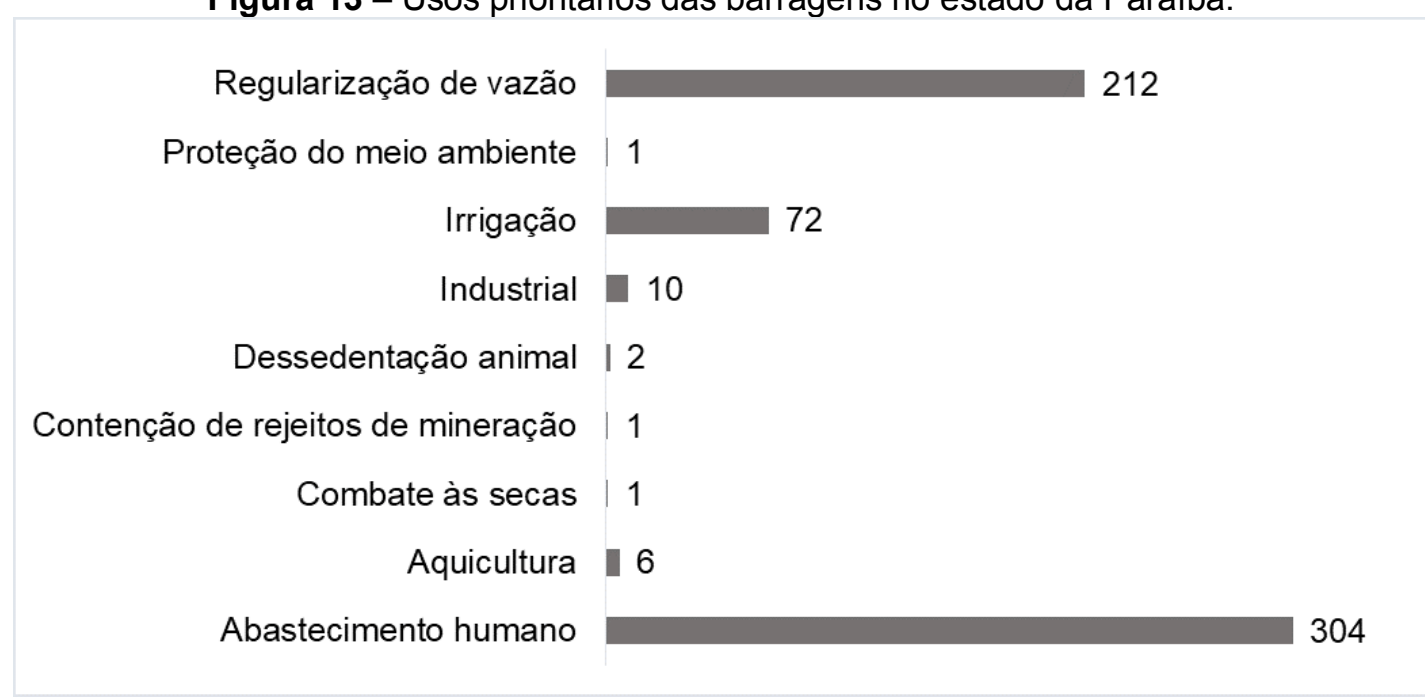

Fonte: Adaptado de ANA (2020). 


\subsection{CENÁRIO MUNICÍPIO DE SUMÉ}

O município de Sumé tem quatro barragens cadastradas no SNISB e 65 feições identificadas como massas de água - a distribuição espacial está ilustrada na Figura 14. Na Tabela 14 são apresentadas as informações sobre as barragens cadastradas no SNISB do município de Sumé.

Figura 14 - Distribuição espacial das massas de águas e barragens cadastradas no SNISB do município de Sumé.

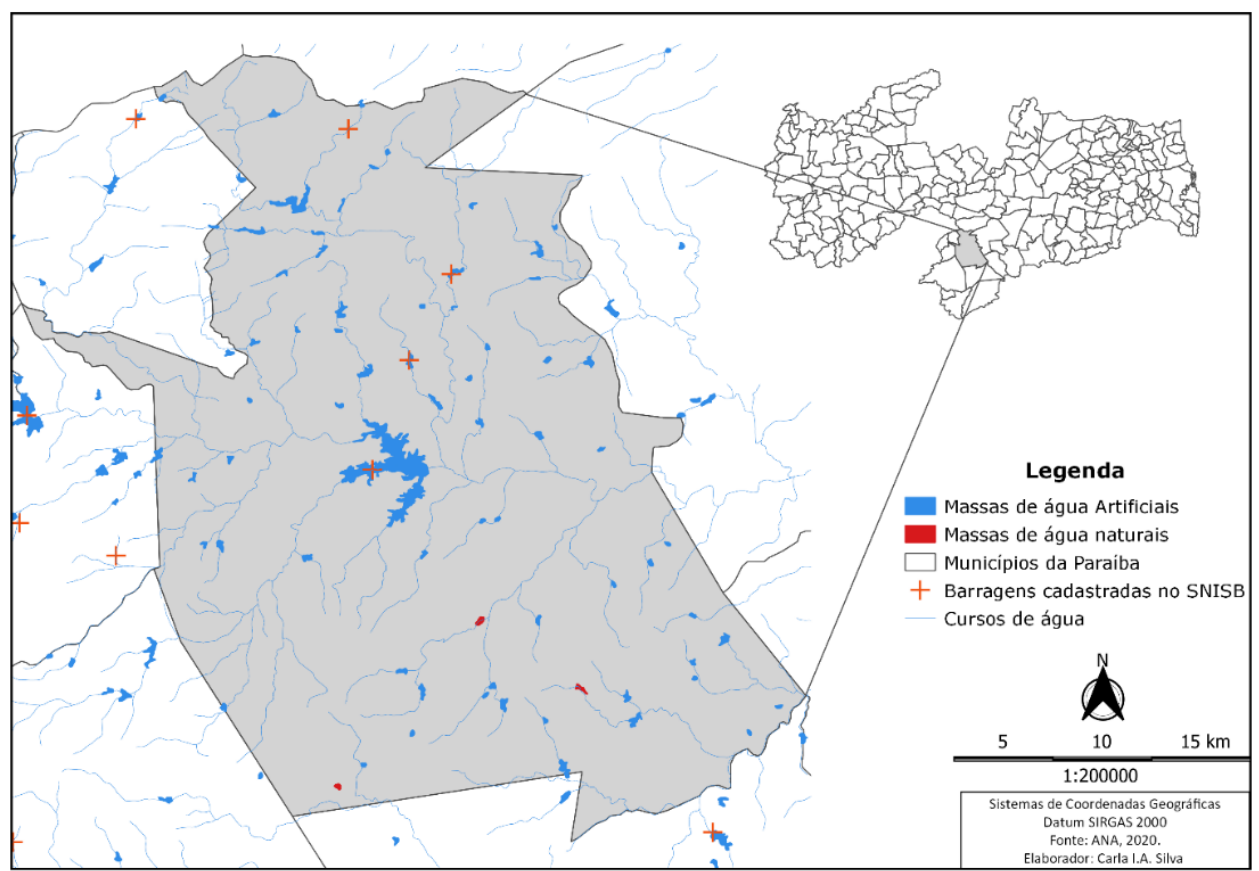

Fonte: Própria autora.

Tabela 14 - Características das barragens de Sumé.

\begin{tabular}{llcccc}
\hline \multicolumn{1}{c}{ Nome } & Uso principal & DPA & $\mathbf{V}\left(\mathbf{h m}^{3}\right)$ & Material & Regulada \\
\hline Sumé & Abastecimento Humano & Alto & 44,864 & Terra & Sim \\
Olho d'Água dos Brancos & Regularização de vazão & $\mathrm{NC}$ & $\mathrm{SI}$ & $\mathrm{SI}$ & $\mathrm{SI}$ \\
Pedra d'Água & Regularização de vazão & $\mathrm{NC}$ & $\mathrm{SI}$ & $\mathrm{SI}$ & $\mathrm{SI}$ \\
Mulungu & Regularização de vazão & $\mathrm{NC}$ & $\mathrm{SI}$ & $\mathrm{SI}$ & $\mathrm{SI}$ \\
\hline
\end{tabular}

Fonte: Própria autora. 


\subsection{AQUISIÇÃO E PROCESSAMENTO DAS IMAGENS}

Os resultados foram dispostos de forma similar à disposição descrita na metodologia, de forma a facilitar o entendimento e o fluxo lógico da metodologia. Assim, os resultados foram divididos em dois grupos: identificação das massas d'água e a aplicação da metodologia proposta resultando no grau de hierarquização para barragem analisada.

\subsubsection{Obtenção e Processamento das Imagens de Satélite}

A identificação automática dos reservatórios utilizando imagens MSI/Sentinel2 demonstrou que a metodologia utilizada foi adequada na identificação do alvo. 0 filtro aplicado para remoção de nuvens se mostrou eficaz, as imagens não apresentaram nuvens que prejudicassem a obtenção dos produtos necessários para análise. Nessa primeira etapa foi realizada a composição das imagens RGB e a posterior transformação para o espaço HSV e os produtos podem ser observados na Figura 15.

Analisando os resultados obtidos através do processamento do GEE, observase, na Figura 16, uma imagem ampliada das composições coloridas, os perfis de água delineados de forma bem consistente. Smith (1978) afirma que, em contraste com o espaço de cores RGB padrão, onde as informações de cores e sua intensidade são geralmente indistintas, no espaço HSV, que usa matiz, saturação e brilho para representação da cor, a segmentação das imagens para extração de pixels de água sobre os demais é facilitada. Ngoc et al. (2019), em estudo sobre como as nuvens afetam as informações obtidas a partir de sensoriamento remoto para identificação de corpos d'água, explica em sua pesquisa que o espaço de cores HSV apresenta uma melhor distinção entre pixels de água e a sombra causada por nuvens.

Os produtos gerados nessa etapa apresentaram boa qualidade nos resultados e foram a base para todo o processo de extração das massas d'água, a qualidade destes produtos afeta diretamente o resultado das demais etapas da metodologia. 
Figura 15 - Resultado da composição das imagens RGB e HSV. (a) Composição RGB; (b) Composição HSV.

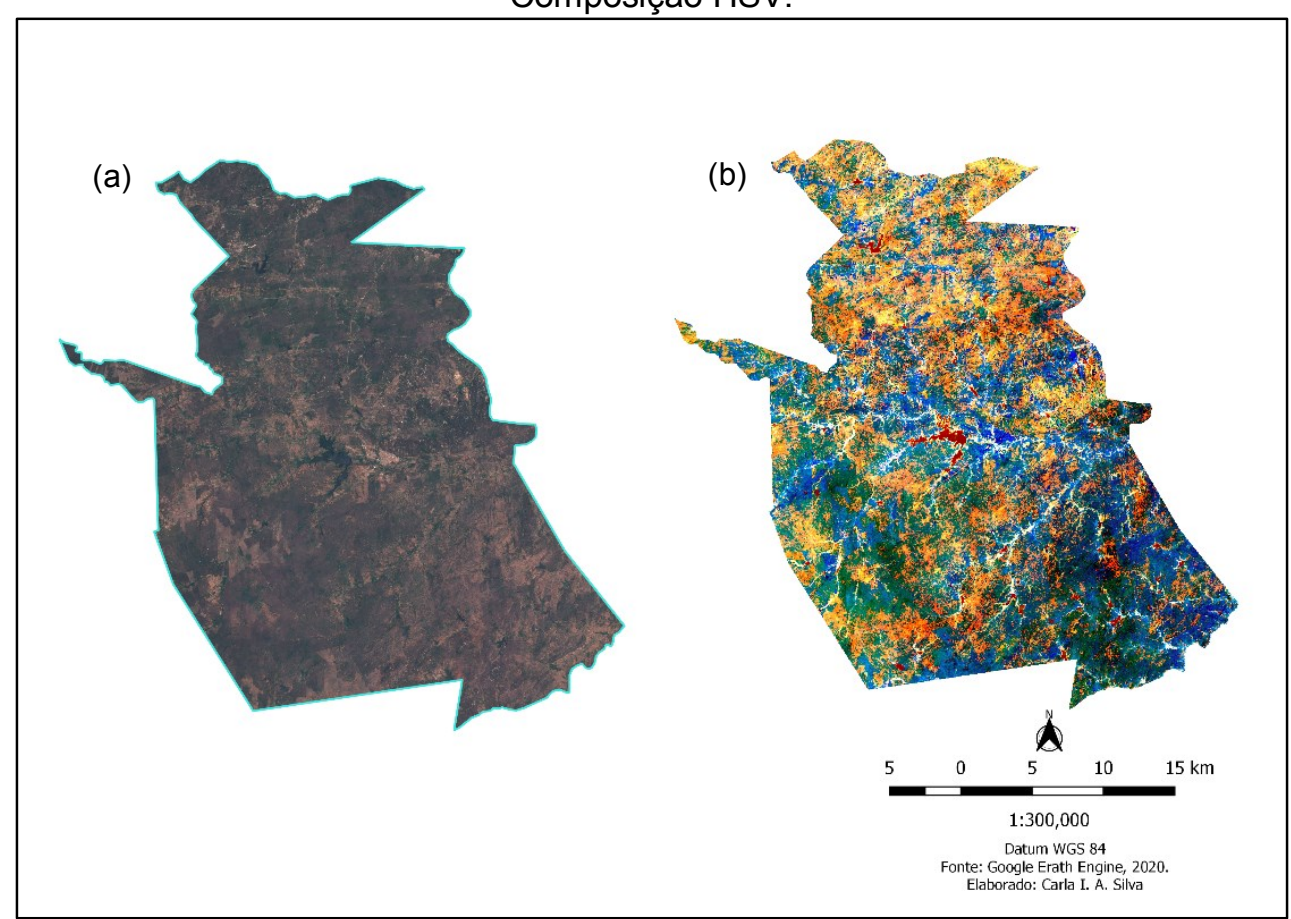

Fonte: Própria autora.

Figura 16 - Imagem ampliada das composições coloridas do município de Sumé. (a) Reservatório com 12.006 hectares no HSV; (b) Reservatório com 12.006 hectares no RGB; Reservatório com 10.484 hectares no HSV; (b) Reservatório com 10.484 hectares no RGB.

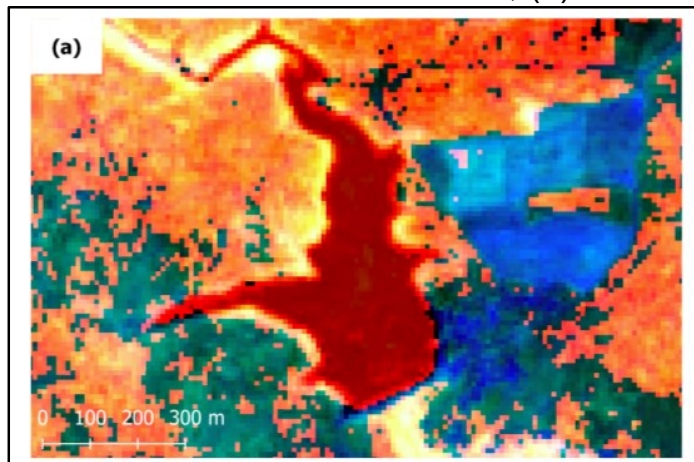

(b)
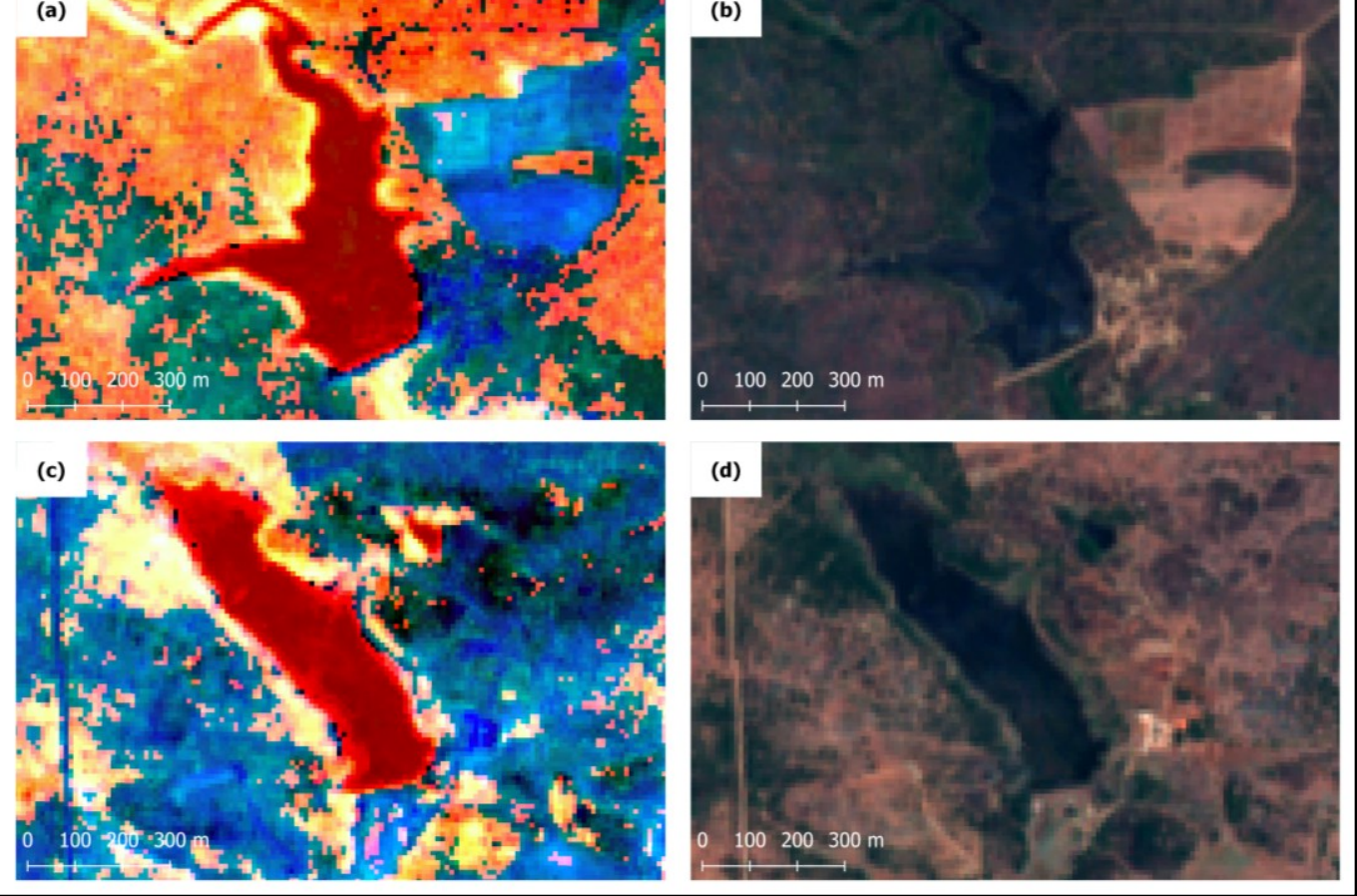

Fonte: Própria autora. 


\subsection{CLASSIFICAÇÃO DAS IMAGENS E EXTRAÇÃO DOS ESPELHOS D'ÁGUA}

O resultado da identificação e extração automática das massas d'água através do $G E E$, pelos índices propostos, em formato tipo raster, pode ser observado na Figura 17. Nessa primeira etapa de identificação ainda não há distinção entre lagos, lagoas, pequenas barragens, ruídos, alguns segmentos de rios e açudes. Logo, não são produtos conclusivos da área de superfícies dos espelhos d'água de pequenas barragens. Para tal finalidade, os dados precisam ser classificados de acordo com os critérios estabelecidos na metodologia.

Figura 17 - Massas d'água extraídas do GEE.

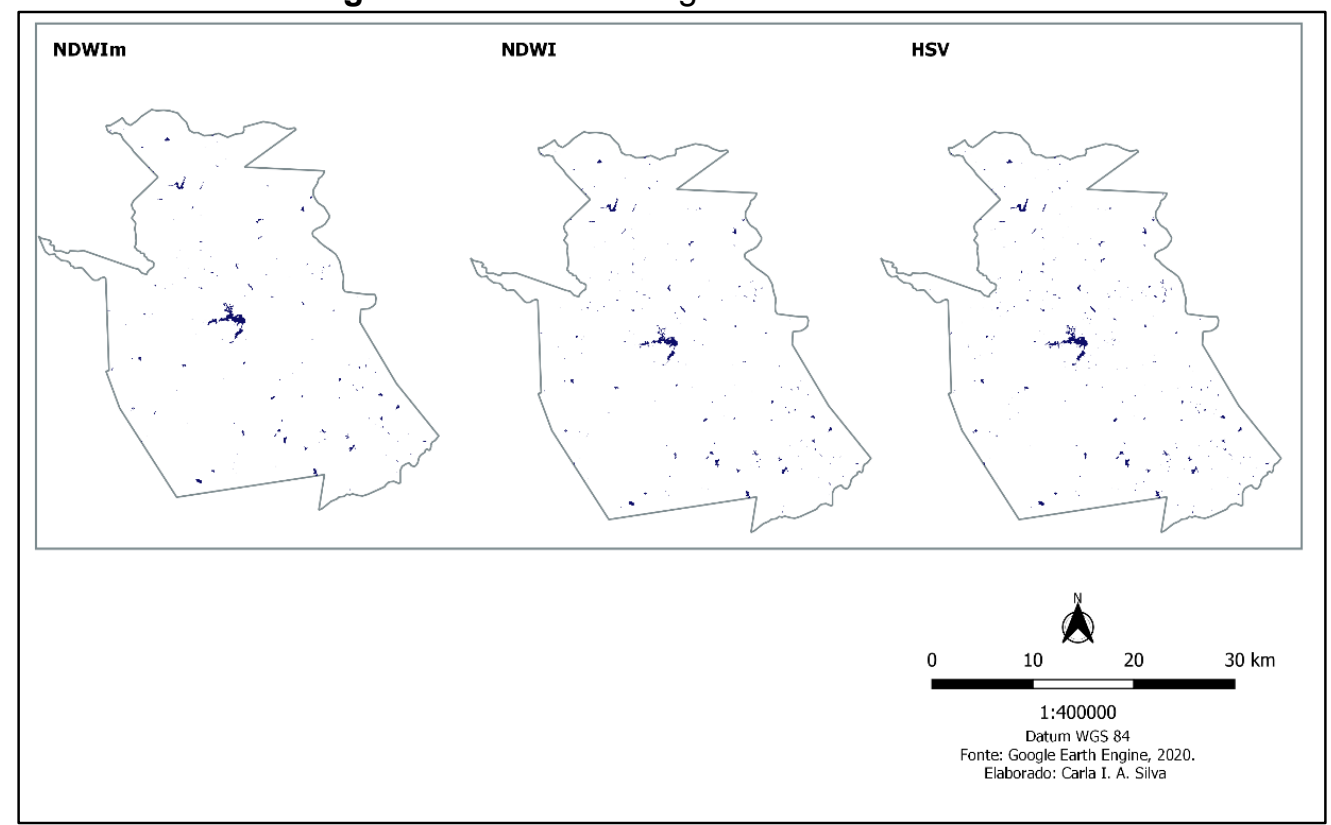

Fonte: Própria autora.

Na Tabela 15 observa-se o quantitativo de massas d'água, após o processo de classificação. Verifica-se que o produto gerado pela composição de cores HSV identificou mais feições, sendo mais eficiente na detecção de pequenos reservatórios.

O processo de classificação consistiu em eliminar ruídos das imagens e estabelecer a relação dos reservatórios com a rede de drenagem. Observa-se na Tabela 16 a área superficial das massas d'água identificadas, verifica-se que $97 \%$ das massas d'água classificadas tem área inferior a 20 ha, o que já foi afirmado por Santos (2009), na pesquisa aplicada na bacia do açude de Sumé onde $98 \%$ das imagens identificadas por satélite têm área inferior a 20 ha. 
Tabela 15 - Quantitativo de massas d'água identificadas.

\begin{tabular}{lc}
\hline \multicolumn{1}{c}{ Identificador } & Número de reservatórios \\
\hline Massas d'água ANA & 65 \\
$\mathrm{NDWI}$ & 65 \\
$\mathrm{NDWI}$ & 58 \\
$\mathrm{HSV}$ & 74 \\
\hline
\end{tabular}

Fonte: Própria autora.

Nota-se, de acordo com as informações da Tabela 16, que apenas dois reservatórios no município de Sumé apresentam área superficial superior a 20 hectares, representando apenas $3 \%$ do total de reservatórios, ficando assim comprovado que a grande maioria dos espelhos d'água da região, é de pequenos açudes, com área entre 1 e 20 hectares. Fato que corrobora com Molle (1994), Santos et al. (2009), Gheyi et al. (2011) e Almeida (2018), que a presença de pequenos açudes no semiárido nordestino, já contabilizados em torno de 70.000 na década de 1990, é consequência da política estabelecida na região, que objetiva armazenar água durante os períodos chuvosos para posterior utilização em períodos de seca, reduzindo assim a vulnerabilidade da população à seca.

Tabela 16 - Área dos espelhos d'água extraídos.

\begin{tabular}{lllllll}
\hline Área (ha) & HSV & \multicolumn{3}{c}{ NDWI } & \multicolumn{3}{c}{ NDWIm } \\
\hline $1-2$ & 22 & $30 \%$ & 24 & $37 \%$ & 18 & $31 \%$ \\
$2-3$ & 14 & $19 \%$ & 9 & $14 \%$ & 11 & $19 \%$ \\
$3-4$ & 8 & $11 \%$ & 6 & $9 \%$ & 4 & $7 \%$ \\
$4-5$ & 4 & $5 \%$ & 3 & $5 \%$ & 4 & $7 \%$ \\
$5-10$ & 16 & $22 \%$ & 15 & $23 \%$ & 14 & $24 \%$ \\
$10-20$ & 8 & $11 \%$ & 6 & $9 \%$ & 5 & $9 \%$ \\
Acima 20 & 2 & $3 \%$ & 2 & $3 \%$ & 2 & $3 \%$ \\
\hline
\end{tabular}

Fonte: Própria autora. 
Figura 18 - Imagens antes e depois do processo de classificação, quanto a área e a interseção das superfícies dos espelhos d'água com a rede de drenagem.

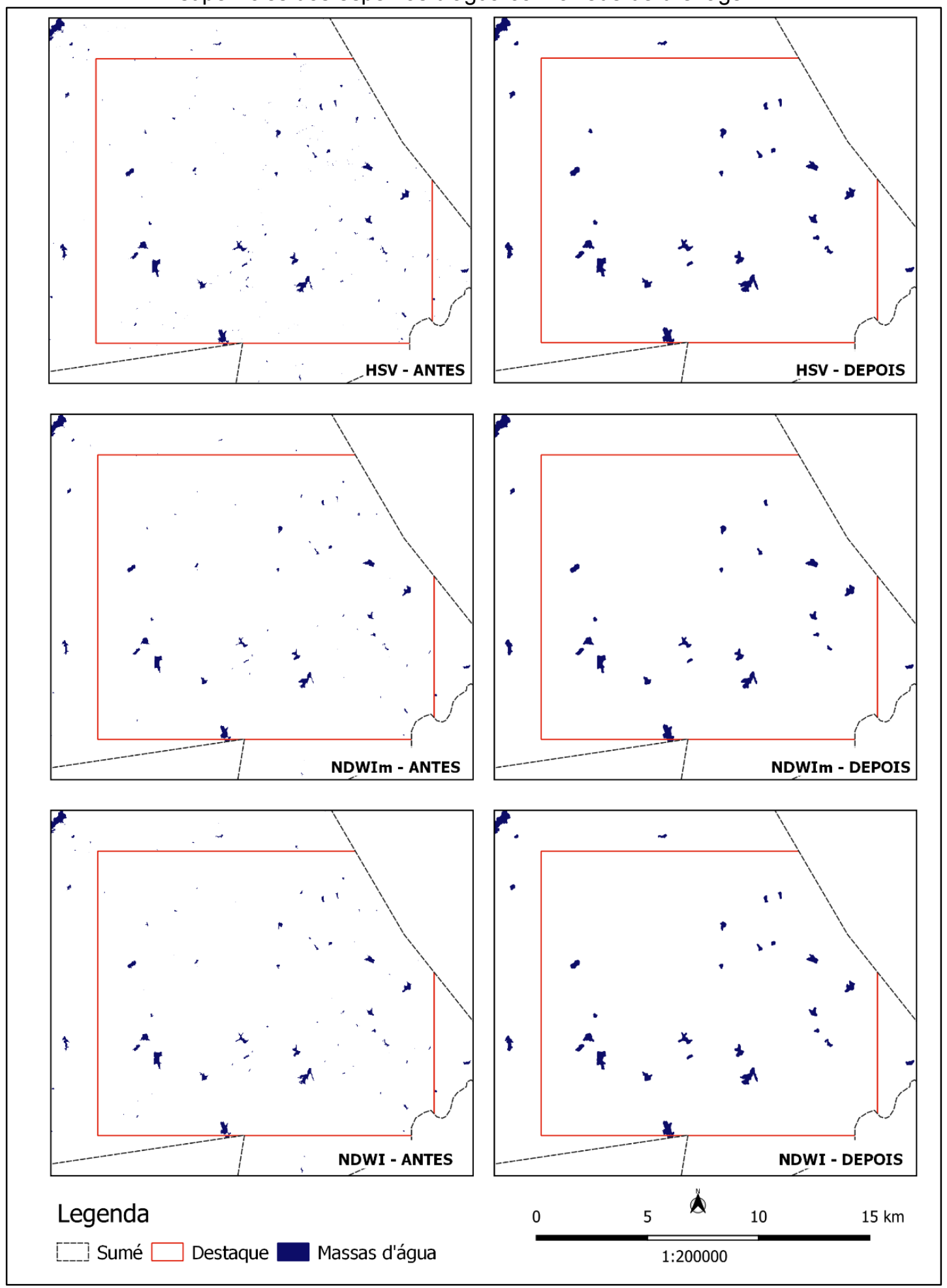

Fonte: Própria autora.

Entretanto, segundo Huang et al. (2018) uma elevada densidade de pequenos reservatórios, que retém o escoamento, podem reduzir o reabastecimento dos 
grandes reservatórios a jusante, sendo esse fenômeno mais significativo em anos com déficit de precipitação, pois não há vazão suficiente para transbordamento dos pequenos açudes enquanto a demanda da região permanece a mesma, causando assim a diminuição acelerada no armazenamento de água superficial nesses corpos d'água.

Para ilustrar melhor os resultados obtidos, pode-se observar na Figura 190 mosaico da composição colorida RGB e a identificação dos respectivos índices calculados, para o período de 2020. Comparando-se o resultado dos índices com a composição RGB, pode-se afirmar que a superfície resultado da transformação do espaço de cores RGB para HSV (Figura 19.b) apresentou os melhores resultados, com um melhor realce dos corpos d'água. Nota-se que o NDWIm (Figura 19.d) também apresentou um realce significativo, pode-se afirmar que esses melhores resultados são justificados pelo uso da banda SWIR, tornando o índice menos suscetível concentrações de sedimentos e outros constituintes orgânicos dentro da água do que a banda NIR (HUANG et al., 2018).

Figura 19 - Resultados da extração das massas d'água. (a) Composição RGB; (b) Resultado extraído da composição HSV, sobreposto a imagem RGB; (c) Resultado NDWI, sobreposto a imagem RGB e d) Resultado NDWIm, sobreposto a imagem RGB.

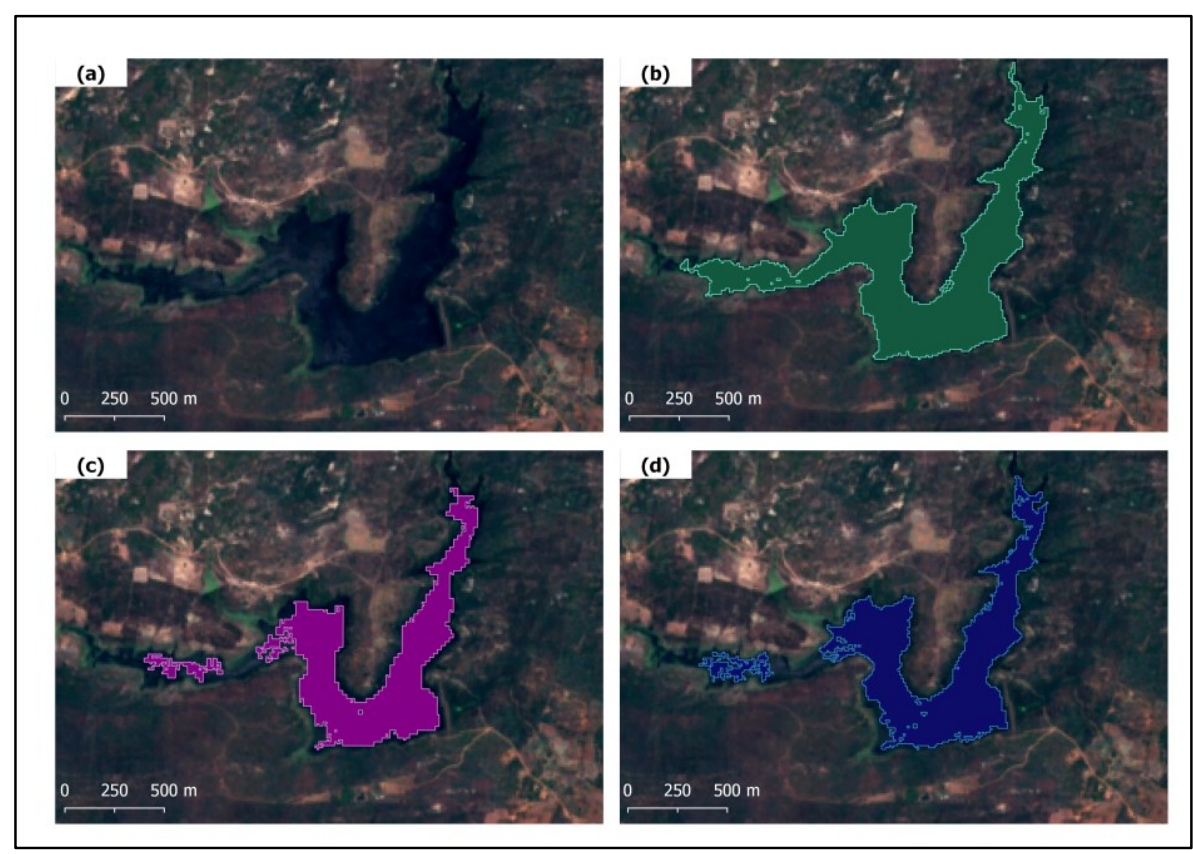

Fonte: Própria autora. 


\subsubsection{Avaliação da Extração dos Espelhos d'água}

Para avaliação da extração dos corpos d'água, as superfícies extraídas do GEE foram comparadas com a base de dados do mapeamento das massas d'água disponibilizada pela ANA. Foram identificadas 45 feições coincidentes geograficamente, destas 43 apresentavam área inferior a 20 hectares. Foram dispostos espacialmente, de forma aleatória, três reservatórios distintos para comparação visual entre os resultados obtidos e a base da ANA (2020). Observa-se na Figura 20 a disposição espacial de três reservatórios distintos, pontos (a), (b) e (c), e as respectivas feições identificadas pelos índices propostos. Observa-se nas Figuras 20 (a.1), (b.1), (c.1) a composição colorida RGB e a área destacada em vermelho corresponde a área definida pela superfície do espelho d'água disponibilizado pela ANA (2020). As Figuras 20 (a.2), (b.2), (c.2) correspondem as superfícies delineadas pelo HSV, as Figuras 20 (a.3), (b.3), (c.3) são resultados do NDWI e as Figuras 20 (a.4), (b.4), (c.4) feições obtidas através do NDWIm.

Figura 20 - Comparação entre os índices propostos e a base de dados da ANA (2020).

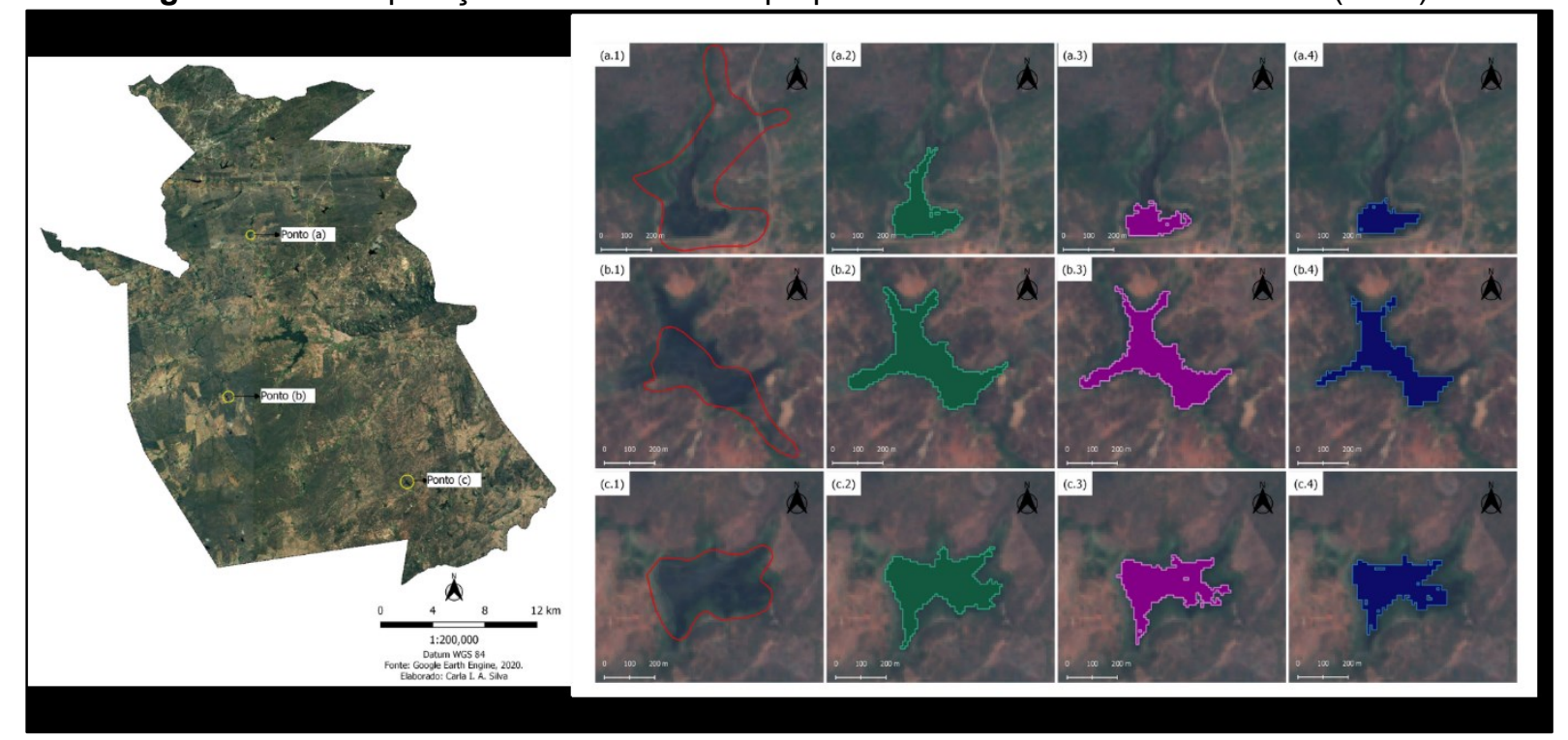

Fonte: Própria autora.

Pode-se concluir das imagens que os resultados obtidos subestimam a área do espelho d'água dos dados disponibilizados pela ANA (2020). Justifica-se esse fato devido a divergência temporal dos dados. A base de dados das feições disponibilizadas pela ANA (2020) apresenta dados de diversos anos e fontes, algumas 
feições também passaram por um processo de digitalização manual por meio de edição em SIG sobre geo web services de imagens de satélite, também foram consideradas as imagens com maior área superficial da massa d'água, para que o volume associado esteja o mais próximo possível da capacidade total de armazenamento (ANA, 2020). Como os resultados refletem a presença de água é possível que a análise em períodos com diferentes índices pluviométricos, gerem diferentes superfícies. O que pode ser considerado um ponto positivo, pois é possível monitorar o perfil dessas superfícies entres períodos chuvosos e secos.

Os corpos d'água são dinâmicos, se retraem e expandem com o tempo, devido uma série de fatores naturais e antrópicos, essas variações têm impacto significativo na obtenção das superfícies dos espelhos d'água por imagens de satélite. Huang et al. (2018) afirmam que deve ser realizado o monitoramento dessas variações no espaço-tempo, para que haja um melhor entendimento da dinâmica dessas massas d'água, da disponibilidade do recurso e a percepção sobre os processos naturais que moldam o armazenamento dos recursos hídricos.

Para análise estatísticas dos dados aplicaram-se as métricas RMSE e MAE, que expressam o erro médio do modelo preditivo, os resultados estão listados na Tabela 17.

Tabela 17 - Resultado das métricas RMSE e MAE.

\begin{tabular}{lcccccc}
\hline Classes & \multicolumn{3}{c}{ RMSE } & & \multicolumn{3}{c}{ MAE } \\
& HSV & NDWI & NDWIm & HSV & NDWI & NDWIm \\
\hline Total da Amostra & 4,38 & 4,86 & 5,19 & 3,35 & 3,74 & 4,10 \\
$1-5$ ha & 1,94 & 2,03 & 2,17 & 1,60 & 1,79 & 1,88 \\
$5-10$ ha & 4,36 & 4,45 & 4,68 & 3,54 & 3,71 & 4,08 \\
$10-15$ ha & 5,31 & 4,71 & 5,28 & 3,38 & 4,35 & 4,76 \\
$15-20$ ha & 8,20 & 9,05 & 9,48 & 6,51 & 6,95 & 7,71 \\
\hline
\end{tabular}

Fonte: Própria autora.

Como já abordado anteriormente, as áreas modeladas apresentam uma divergência acentuada quando comparadas as áreas consideradas "reais", que são as feições disponibilizadas pela ANA (2020). Esses erros, na métrica RMSE, são 
ampliados, pois são elevados ao quadrado, ou seja, outliers nos conjuntos de dados aumentam o erro consideravelmente. Já a MAE não penaliza tão severamente os outliers, apresentando assim erros menores. De acordo com as métricas analisadas o método HSV apresentou os melhores resultados.

Para uma melhor compreensão dos dados realizou-se uma análise estatísticas dos dados separados por classes de área superficial. Observa-se na Tabela 17 uma menor variação entre os dados analisados nos reservatórios com superfícies entre 1 e 5 ha, corroborando a afirmação de Huang et al. (2018), que a dinâmica da recarga e do esgotamento dos reservatórios varia de acordo com o tamanho do mesmo, onde reservatórios grandes apresentam diminuições drásticas e contínuas durante períodos de seca enquanto reservatórios menores respondem quase instantaneamente ao déficit ou aporte de precipitação. Apesar do ano de 2020 ter apresentado níveis de precipitação mais elevados, quando comparado aos anos anteriores, os níveis dos reservatórios maiores podem não ter atingindo seus níveis máximos de área superficial.

A maior quantidade dos reservatórios identificados apresenta área entre um e cinco hectares, em torno de $65 \%$ dos espelhos d'água. Uma elevada densidade de pequenos reservatórios, em regiões com baixa disponibilidade hídrica comprova a cultura de armazenamento de água dessas regiões, como afirma Almeida (2018) . O método HSV foi consolidado como o mais eficaz dentre os índices analisados, para o período de estudo, apresentando uma boa representação visual e o menor erro na análise estatística.

\subsection{DEFINIÇÃO DE CRITÉRIOS E MATRIZ DE HIERARQUIZAÇÃO}

\subsubsection{Definição da Área para Aplicação da Metodologia}

Após a identificação das massas d'água escolheu-se a barragem 1065 para ilustrar a aplicação dos demais passos da metodologia. A barragem que foi analisada e sua bacia de contribuição estão representadas na Figura 21. A barragem apresenta uma área superficial de 10,48 hectares. Realizando-se uma análise qualitativa da forma da bacia, observa-se uma forma mais alongada. Segundo Esper Angillieri e 
Fernandez (2017) bacias com forma mais alongada apresentam fluxos de vazão mais planos e baixa acumulação do deflúvio diminuindo o risco inundação nas condições normais.

Figura 21 - Barragem de interesse e bacia de contribuição.

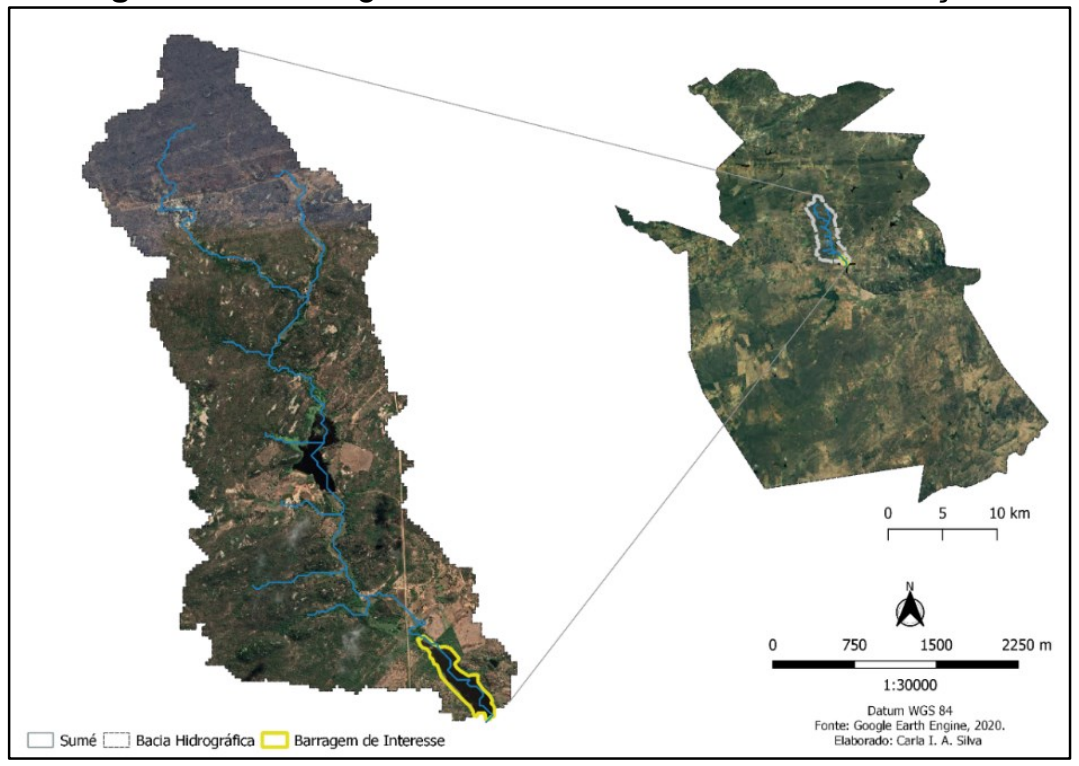

Fonte: Própria autora.

\subsubsection{Análise dos Critérios Estruturais Relacionados à Barragem (CE)}

O critério $C E_{1}$ definido na seção 3.3.1 como uma estimativa relacionada a idade da barragem foi obtido pelo GEE. A análise dos dados obtidos através do GEE para barragem analisada apresentou a presença de água a partir de junho de 1984. A Figura 22 ilustra o perfil dos dados coletados, onde:

- 0 indica que não há dados para o período;

- 1 indica ausência de água;

- 2 indica presença de água. 
Figura 22 - Perfil temporal da presença de água na barragem analisada.

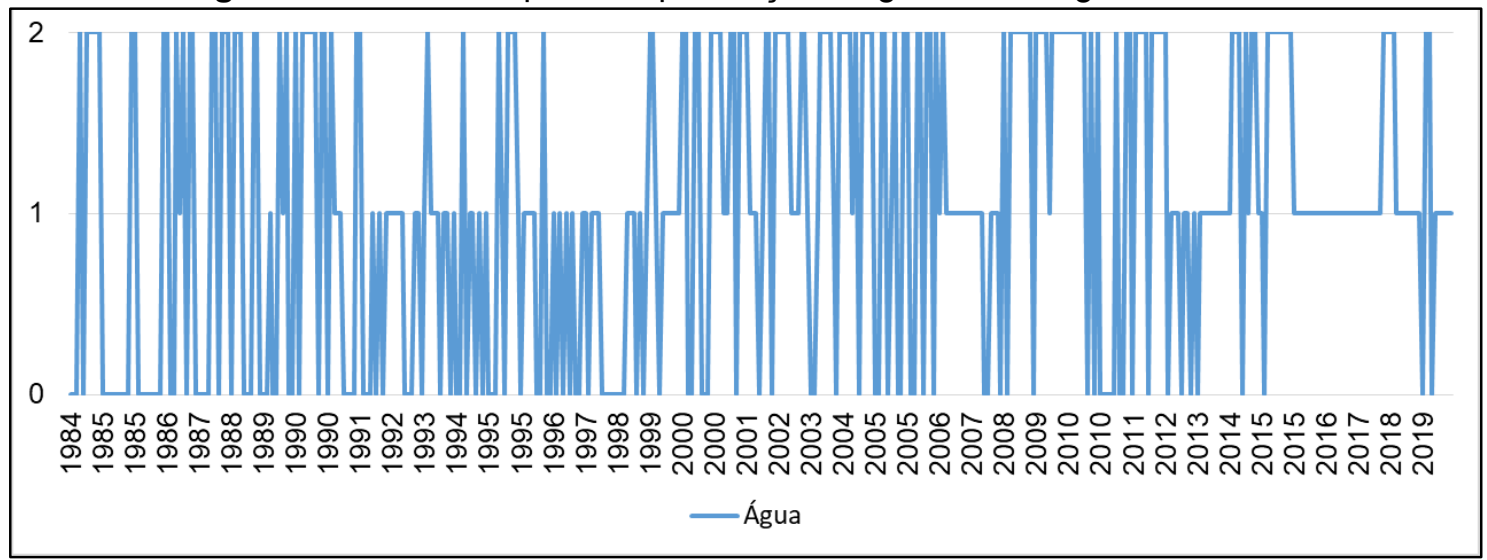

Fonte: Própria autora.

Através da análise dos dados conclui-se que para o critério $C E_{1}$ a barragem pertence a classe 1 , entre 30 e 50 anos.

$\mathrm{O}$ critério $C E_{2}$ classifica a barragem quanto a existência de barragens a montante do reservatório analisado, caracterizando barragens em cascata, o que pode elevar o risco de rompimentos em série. Como afirma Viseu (2008) o rompimentos de barragens pode ser agravado no caso das barragens a jusante serem igualmente destruídas ou danificadas pela cheia proveniente de montante. De acordo com o exposto na Figura 21, correspondente a área em estudo, pode-se verificar que existe a presença de um reservatório a montante, a uma distância aproximada de 2,5 $\mathrm{km}$ da barragem analisada, com isso o $C E_{2}$ será da classe 2, existência de um ou dois barramentos a uma distância de $5 \mathrm{~km}$.

$\mathrm{O} C E_{3}$ classifica a barragem quanto ao volume total do reservatório. A área da superfície considerada para análise foi a área calculada através da transformação HSV, totalizando uma área de 10,48 ha. O cálculo do volume foi estimado de acordo com Equação 5, seção 3.4.1, proposta por Molle (1994), considerando $S=104.840$ $\mathrm{m}^{2}$ e a $\mathrm{DM}=0,010 \mathrm{~m} / \mathrm{m}$. O volume estimado do reservatório é de aproximadamente $26.860,34 \mathrm{~m}^{3}$, o que classifica o reservatório como classe 1. Estão apresentados na Tabela 18 os resultados dos critérios analisados nesta etapa do trabalho. 
Tabela 18 - Resultados dos critérios estruturais analisados.

\begin{tabular}{cc}
\hline Critérios Estruturais & Valor \\
\hline$C E_{1}$ & 1,0 \\
$C E_{2}$ & 2,0 \\
$C E_{3}$ & 1,0 \\
\hline
\end{tabular}

Fonte: Autoria própria.

Após a definição dos valores dos critérios estruturais pode-se calcular a Classificação de Risco Potencial (CRP), através da média simples dos CE (Equação 12).

$$
C R P=\frac{C E_{1}+C E_{2}+C E_{3}}{3} \therefore \frac{1+2+1}{3} \cong 1,33
$$

Quanto ao risco potencial a barragem foi classificada como classe 1, de baixo risco potencial. A análise de risco potencial baseada em métodos de análise simplificados, que não quantificam matematicamente o risco, apenas atribuem pesos representativos a um conjunto de parâmetros é qualitativo, como afirma Menescal et al. (2001), que apesar da representação numérica não foram utilizados métodos estatísticos. Segundo Viseu (2008), o risco potencial é a quantificação dos danos e consequências em casos de acidentes que independem da probabilidade de ocorrência. Sendo interpretado como o total de prejuízos e perdas esperados em consequência da cheia, ou seja, a quantidade de pessoas, recursos econômicos e ambientais estão suscetíveis na área de inundação.

\subsubsection{Análise dos Critérios para Caracterização do Vale a Jusante}

Para análise do vale a jusante realizou-se a definição da área de influência como proposto na metodologia, e realizou-se a análise visual em busca dos alvos de interesse para análise. Observa-se na Figura 23 a região de interesse. A área tem uma distância linear de $5 \mathrm{~km}$ seguindo o curso da drenagem e largura igual e 200 metros. Para barragens onde não é possível obter certeza quanto aos riscos de acidentes e consequências em caso de colapso, a orientação de Brasil (2010) é que deve-se utilizar uma análise simplificada e conservadora, quanto as análises 
preliminares. Verifica-se na Figura 23 que a área atinge o centro urbano de Sumé, mostrando a vulnerabilidade da região.

Figura 23 - Área de interesse a jusante da barragem.

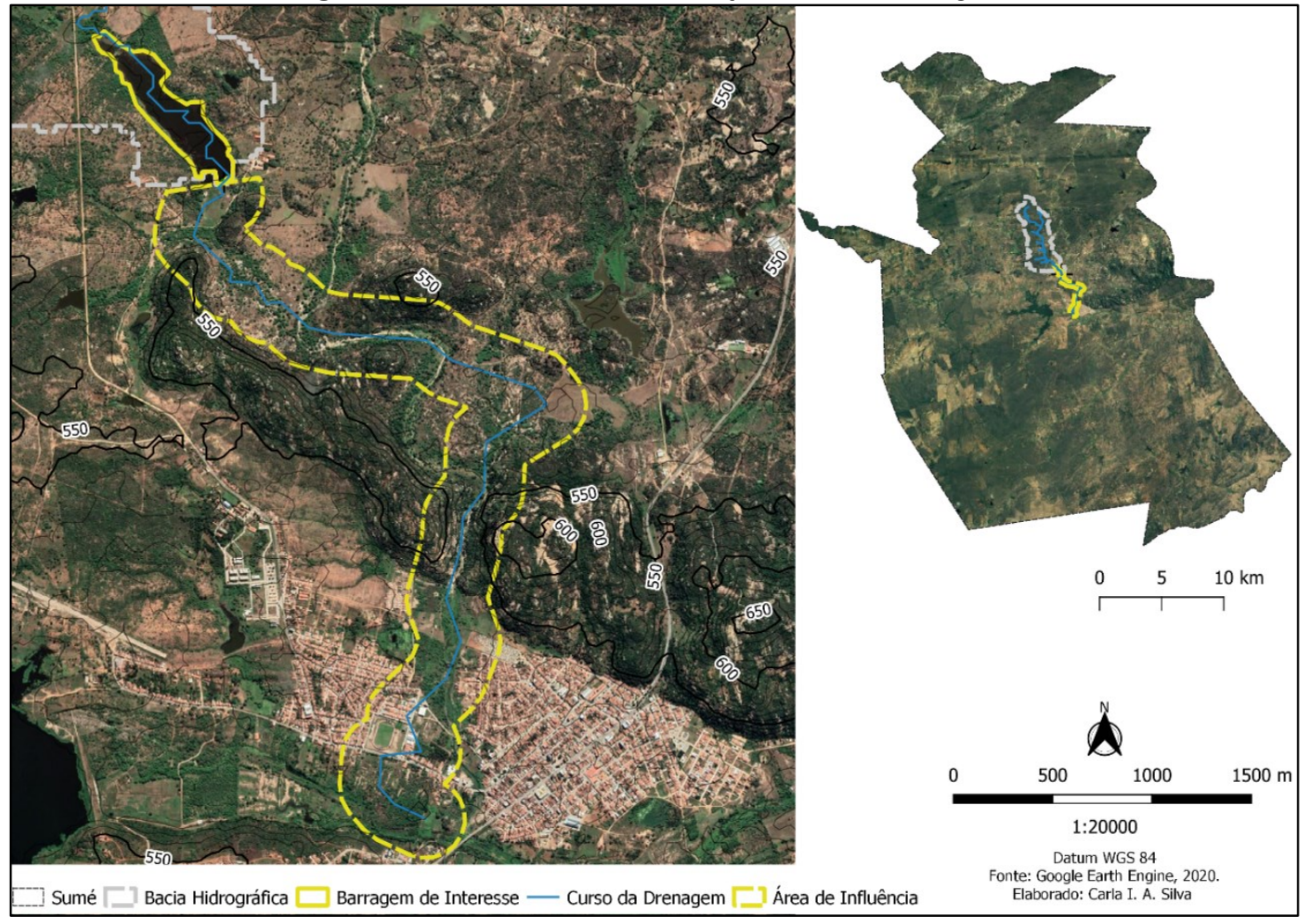

Fonte: Própria autora.

\subsubsection{Cálculo do Índice de Risco Associado (IRA)}

O indicador demográfico foi calculado de acordo com a metodologia proposta. Foi identificada uma densa área urbana na área de influência, diante desse fato o $I_{\text {dem }}$ será de classe 4 (mais de 100 pessoas expostas). Para o indicador econômico ( $\left.I_{\text {eco }}\right)$ não foram identificadas na área atividades agrícolas ou unidades indústrias significativas, sendo considerada apenas para esse indicador os equipamentos de infraestrutura urbana, classificados como classe 4, muito importante. Assim o indicador econômico tem um valor de 1,33.

A classificação quantos aos recursos naturais, o indicador ambiental $\left(I_{a m b}\right)$, também realizada através da análise visual da área de interesse, retornou um valor de 2 (recursos importantes que sofrem impacto no curso prazo, mas se autorregulam 
no médio e longo prazo). Observa-se na Tabela 19 o resultado das análises dos critérios propostos.

Tabela 19 - Resultados dos critérios para caracterização do vale a jusante.

\begin{tabular}{cc}
\hline Critérios IRA & Valor \\
\hline$I_{\text {dem }}$ & 4 \\
$I_{e c o}$ & 1,33 \\
$I_{a m b}$ & 2 \\
\hline
\end{tabular}

Fonte: Própria autora.

O IRA é calculado de acordo com a Equação 13, considerando: $K_{1}=0,5 ; K_{2}=$ 0,$25 ; K_{3}=0,25$.

$$
I R A=K_{1} I_{\text {dem }}+K_{2} I_{e c o}+K_{3} I_{a m b} \therefore 0,5 \times 4+0,25 \times 1,33+0,25 \times 2=2,83
$$

De acordo com os critérios analisados, a barragem apresenta um IRA na classe $3(2,41$ - 3,20), considerado alto. Viseu (2008) afirma que vales a jusante de barragens, que apresentam alta vulnerabilidade, necessitam da implementação de medidas práticas de segurança como planejamento de ações de emergência, melhoria nas condições de vida da população na área de risco e ordenamento do território. Os impactos gerados em áreas a jusante de barragens não decorrem apenas de rompimentos, mas também por falhas operacionais como cheia liberada por vertedouros e obras de descarga, ou mau funcionamento da barragem (ANA, 2014).

\subsubsection{Aplicação da Matriz de Hierarquização}

Concluídos os cálculos do CRP e do IRA é possível classificar a barragem de acordo com a matriz de hierarquização e definir qual o grau de priorização de ações de fiscalização nesse reservatório. Com um CRP Baixo e o IRA Alto, a barragem entra na zona amarela da matriz de hierarquização (Quadro 7), apresentando, assim, um grau de priorização a médio prazo. Para ações de fiscalização do órgão responsável, 
para uma agenda anual, essa barragem pode ser inserida nas vistorias do segundo semestre.

Quadro 7 - Resultado da Matriz de Hierarquização.

\begin{tabular}{|c|c|c|c|c|}
\hline CRP & Muito baixo & Baixo & Médio Alto & Muito Alto \\
\hline $\begin{array}{l}\text { Muito } \\
\text { Baixo }\end{array}$ & & & & \\
\hline Baixo- & & & $\rightarrow$ & \\
\hline Médio & & & & \\
\hline Alto & & & & \\
\hline $\begin{array}{l}\text { Muito } \\
\text { Alto }\end{array}$ & & & & \\
\hline
\end{tabular}

Fonte: Própria autora.

Existem diversas abordagens sobre a gestão e tomada de decisão em processos de segurança de barragens. A abordagem normativa, é a abordagem padrão da engenharia de barragens, em que os riscos são medidos de acordo com o cumprimento das normas técnicas estabelecidas para as situações de projeto, níveis de resistência estrutural e coeficientes de segurança (CNPGB, 2005). Segundo Pimenta (2009), a gestão de segurança de barragens é historicamente orientada para uma abordagem de segurança focada nos processos construtivos, porém é necessário evoluir para uma abordagem orientada para o risco, buscando a integração entre ações, desempenho e consequências. Já a gestão baseada no risco para segurança de barragens é um processo que usa informações sobre o risco para auxiliar a tomada de decisão e demais atividades de segurança da barragem (ANA, 2014). Segundo Nava (2018) uma abordagem integralizadora, com base em estudos técnicos-científicos, deve ser a base para os processos de tomada de decisão, principalmente na gestão dos recursos hídricos que deve ser integrada e participativa. 


\section{CONSIDERAÇÕES FINAIS}

Foram identificadas quatro barragens reguladas no município de Sumé em um universo de 65 massas d'água, evidenciando que os órgãos federais, estaduais e municipais desconhecem a frequência do estabelecimento de pequenos reservatórios e que os bancos de dados são frágeis, não dispondo de informações completas ou confiáveis.

O uso de técnicas de sensoriamento remoto para identificação e classificação das massas de água do município de Sumé, foi considerado eficaz, uma vez que a metodologia proposta foi capaz de identificar pequenos reservatórios com área entre um e vinte hectares como barragens em potencial. A classificação proposta baseada nas variáveis, área e interseção dos polígonos com a rede de drenagem, apresentou um bom desempenho, eliminando ruídos e reservatórios que não eram objeto da pesquisa.

A transformação do espaço RGB para o espaço HSV foi a técnica que apresentou melhores resultados, com perfis mais delineados e com maior número de feições identificadas, um total de 74 espelhos d'água, quando comparado com os demais índices espectrais. A maioria das massas d'água apresentou área entre 1 e 5 hectares, em torno de $65 \%$ das feições identificadas.

Os recursos computacionais utilizados no desenvolvimento deste trabalho (computação em nuvem) permitiram um rápido processamento das imagens na etapa de identificação e extração dos espelhos d'água. O conjunto da dados do Sentinel-2 apresentou bons produtos para identificação dos alvos analisados, devido a sua alta resolução.

Os critérios para avaliação do vale a jusante apresentados na seção 3.4 , são baseados no conceito de dano potencial possível, apresentando uma classificação baseada no números de pessoas expostas, potencial econômico e dos recursos naturais da região de interesse, as variáveis foram facilmente verificadas através de imagens de alta resolução do Google Earth.

A aplicação da matriz de hierarquização e a definição do grau de hierarquização também atenderam aos objetivos propostos. Foi possível estabelecer o grau de hierarquização para a barragem analisada de forma satisfatória. O modelo 
desenvolvido, baseado na análise de risco potencial através de análises numéricas qualitativas, evidencia a importância da análise do especialista, uma vez que uma mesma barragem pode ter mais uma classificação a depender no perfil do analista, atores-chaves no processo de gestão das barragens e recursos hídricos em geral.

Portanto, pode-se afirmar que a metodologia proposta se apresentou eficaz para uma análise qualitativa, baseada em parâmetros técnicos, de fácil obtenção, com imagens de satélite obtidas de bases gratuitas e processadas, com o uso do aplicativos gratuitos como GEE e QGIS, processadas na "nuvem" de forma gratuita, com resultados satisfatórios que pode ser obtidos para o Brasil inteiro pelos órgãos gestores de recursos hídricos para auxiliar no processo de tomada de decisão e gestão de pequenas barragens.

Por fim, este estudo contribui com a proposta de uma metodologia simplificada que colabora para identificação e classificação de pequenas barragens de água para fins de regulação e fiscalização por parte dos órgãos gestores de recursos hídricos. Recomenda-se a aplicação da metodologia em campo, para que os parâmetros sejam testados e validados no intuito de se criar uma massa crítica em relação ao modelo proposto e poder desta forma corroborar as soluções apresentadas. 


\section{REFERÊNCIAS}

AGUIAR, Daniel Prenda de Oliveira et al. Contribuição ao estudo do índice de segurança de barragens - ISB. Revista Brasileira de Recursos Hídricos, v. 20, n. 2, pp. 360-368, 2015. Disponível em:

<https://www.abrhidro.org.br/SGCv3/publicacao.php?PUB=1\&ID=157\&SUMARIO=5 061>. Acesso em: 07 fev. 2021.

ALMEIDA, Thiago Franklin Santos de. Influência de pequenos reservatórios no escoamento superficial da bacia hidrográfica do rio Carinhanha. $134 \mathrm{p}$.

Dissertação (Mestrado) - Universidade Federal de Pernambuco. CTG. Programa de Pós-Graduação em Engenharia Civil, 2018. Disponível em:

<https://repositorio.ufpe.br/bitstream/123456789/33018/1/DISSERTA\%c3\%87\%c3\% 830\%20Thiago\%20Franklin\%20Santos\%20de\%20Almeida.pdf>. Acesso em: 13 fev. 2021.

ANA - AGÊNCIA NACIONAL DE ÁGUAS E SANEAMENTO BÁSICO. Conjuntura dos recursos hídricos no Brasil 2018: informe anual. Brasília: ANA, 2018.

Disponível em: <http://www.snirh.gov.br/portal/snirh/centrais-deconteudos/conjuntura-dos-recursos-hidricos/informe_conjuntura_2018.pdf>. Acesso em: 07 fev. 2021.

ANA - AGÊNCIA NACIONAL DE ÁGUAS E SANEAMENTO BÁSICO. Manual de Políticas e Práticas de Segurança de Barragens para Entidades Fiscalizadoras. Brasília - DF: ANA, 2017.

ANA - AGÊNCIA NACIONAL DE ÁGUAS E SANEAMENTO BÁSICO. Relatório de Segurança de Barragens 2019. Brasília: ANA, 2020. Disponível em: $<$ http://www.snisb.gov.br/portal/snisb/relatorio-anual-de-seguranca-debarragem/2019/rsb19-v0.pdf>. Acesso em: 07 fev. 2021.

ANA - AGÊNCIA NACIONAL DE ÁGUAS E SANEAMENTO BÁSICO. Resolução ANA n 379, de 21 de março de 2013. Aprova o Regulamento do Programa de Consolidação do Pacto Nacional pela Gestão de Águas - PROGESTÃO e dá outras providências. Disponível em:

<http://progestao.ana.gov.br/portal/progestao/progestao-1/o-

programa/normativos/379-2013.pdf>. Acesso em: 07 fev. 2021.

ANA - AGÊNCIA NACIONAL DE ÁGUAS E SANEAMENTO BÁSICO. Programa de Consolidação do Pacto Nacional pela Gestão das Águas - Progestão - 2015. Brasília: ANA, 2016. Disponível em:

<https://progestao.ana.gov.br/portal/progestao/progestao-1>. Acesso em: 07 fev. 2021.

ANA - AGÊNCIA NACIONAL DE ÁGUAS E SANEAMENTO BÁSICO. Resolução $\mathbf{n}^{\circ}$ 132, de 22 de fevereiro de 2016. Estabelece critérios complementares de classificação de barragens reguladas pela Agência Nacional de Águas - ANA, quanto ao Dano Potencial Associado - DPA Disponível em:

<https://arquivos.ana.gov.br/resolucoes/2016/132-2016.pdf> 
ANA - AGÊNCIA NACIONAL DE ÁGUAS E SANEAMENTO BÁSICO. Resolução $\mathbf{n}^{\circ}$ 236, de 30 de janeiro de 2017: Documento $n^{\circ} 00000.005651 / 2017-42$. Estabelece a periodicidade de execução ou atualização, a qualificação dos responsáveis técnicos, o conteúdo mínimo e o nível de detalhamento do Plano de Segurança da Barragem, das Inspeções de Segurança Regular e Especial, da Revisão Periódica de Segurança de Barragem e do Plano de Ação de Emergência, conforme art. $8^{\circ}, 9^{\circ}$, 10, 11 e 12 da Lei $n^{\circ} 12.334$ de 20 de setembro de 2010, que estabelece a Política Nacional de Segurança de Barragens - PNSB. Disponível:

$<$ https://arquivos.ana.gov.br/resolucoes/2017/236-2017.pdf>. Acesso em: 07 fev. 2021.

ANA - AGÊNCIA NACIONAL DE ÁGUAS E SANEAMENTO BÁSICO. Serviços analíticos e consultivos em segurança de barragens. Barragens. Produto 3 . Classificação de Barragens: Melhores Práticas Nacionais e Internacionais. 2014. Disponível em:

$<$ http://www.snisb.gov.br/portal/snisb/Entenda_Mais/publicacoes/ArquivosPNSB_Doc s_Estruturantes/produto-03-2013-classificacao-de-barragens-melhores-praticasnacionais-e-internacionais.pdf>. Acesso em: 07 fev. 2021.

BHANGALE, Ujwala. et al. Analysis of Surface Water Resources Using Sentinel-2 Imagery. Procedia Computer Science, v. 171, n. 2019, pp. 2645-2654, 2020. Disponível em:

$<$ https://www.researchgate.net/publication/341908408_Analysis_of_Surface_Water_ Resources_Using_Sentinel-2_Imagery>. Acesso em: 13 fev. $20 \overline{2} 1$.

BRASIL. Lei $n^{\circ}$ 12.334, de 20 de setembro de 2010. Estabelece a Política Nacional de Segurança de Barragens destinadas à acumulação de água para quaisquer usos, à disposição final ou temporária de rejeitos e à acumulação de resíduos industriais, cria o Sistema Nacional de Informações sobre Segurança de Barragens e altera a redação do art. 35 da Lei no 9.433, de 8 de janeiro de 1997, e do art. 4o da Lei no 9.984 , de 17 de julho de 2000. Disponível em:

<http://www.planalto.gov.br/ccivil_03/_ato2007-2010/2010/lei//12334.htm>. Acesso em: 07 fev. 2021.

BRASIL. Lei $n^{\circ} \mathbf{1 4 . 0 6 6}$, de 30 de setembro de 2020. Altera a Lei $n^{\circ} 12.334$, de 20 de setembro de 2010, que estabelece a Política Nacional de Segurança de Barragens (PNSB), a Lei $n^{\circ} 7.797$, de 10 de julho de 1989, que cria o Fundo Nacional do Meio Ambiente (FNMA), a Lei $n^{\circ} 9.433$, de 8 de janeiro de 1997, que institui a Política Nacional de Recursos Hídricos, e o Decreto-Lei n ${ }^{\circ} 227$, de 28 de fevereiro de 1967 (Código de Mineração). Disponível em:

$<$ https://www.in.gov.br/en/web/dou/-/lei-n-14.066-de-30-de-setembro-de-2020280529982>. Acesso em: 07 fev. 2021.

BRASIL. Lei $n^{\circ} 6.938$, de 31 de agosto de 1981. Dispõe sobre a Política Nacional do Meio Ambiente, seus fins e mecanismos de formulação e aplicação, e dá outras providências. Disponível em: <http://www.planalto.gov.br/ccivil_03/leis//6938.htm>. Acesso em: 07 fev. 2021. 
BRASIL. Lei $\mathbf{n}^{\circ}$ 9.433, de 8 de janeiro de 1997. Institui a Política Nacional de Recursos Hídricos, cria o Sistema Nacional de Gerenciamento de Recursos Hídricos, regulamenta o inciso XIX do art. 21 da Constituição Federal, e altera o art. $1^{\circ}$ da Lei $n^{\circ} 8.001$, de 13 de março de 1990, que modificou a Lei $n^{\circ} 7.990$, de 28 de dezembro de 1989. Disponível em:

<http://www.planalto.gov.br/ccivil_03/leis//9433.htm>. Acesso em: 07 fev. 2021.

BRASIL. Resolução n 143, de 10 de julho de 2012. Estabelece critérios gerais de classificação de barragens por categoria de risco, dano potencial associado e pelo seu volume, em atendimento ao art. $7^{\circ}$ da Lei $n^{\circ} 12.334$, de 20 de setembro de 2010. Brasília: Ministério do Meio Ambiente. Conselho Nacional de Recursos Hídricos, 2012a. Disponível em:

<https://sistemas.anm.gov.br/publicacao/mostra_imagem.asp?IDBancoArquivoArqui vo=7231>. Acesso em: 07 fev. 2021.

BRASIL. Resolução no 144, de 10 de julho de 2012. Estabelece diretrizes para implementação da Política Nacional de Segurança de Barragens, aplicação de seus instrumentos e atuação do Sistema Nacional de Informações sobre Segurança de Barragens, em atendimento ao art. 20 da Lei $n^{\circ}$ 12.334, de 20 de setembro de 2010, que alterou o art. 35 da Lei $n^{\circ}$ 9.433, de 8 de janeiro de 1997. Brasília: Ministério do Meio Ambiente. Conselho Nacional de Recursos Hídricos, 2012b. Disponível em: $<$ https://sistemas.anm.gov.br/publicacao/mostra_imagem.asp?IDBancoArquivoArqui vo=7234>. Acesso em: 07 fev. 2021.

BIEDERMANN, Robert. Safety concept for dams: development of the Swiss concept since 1980. Wasser, Energie, Luft, v. 89, n. 3/4, p. 54-72, 1997.

CNPGB - Grupo de Trabalho de Análise de Riscos em Barragens. $1^{\circ}$ Relatório de Progresso (Janeiro 2005). Lisboa: Comissão Nacional Portuguesa de Grandes Barragens, 2005. Disponível em:

<https://cnpgb.apambiente.pt/imagens/relProgJaneiro05.pdf>. Acesso em: 13 fev. 2021.

DRUSCH, Matthias et al. Sentinel-2: ESA's Optical High-Resolution Mission for GMES Operational Services. Remote Sensing of Environment, v. 120, 15 May 2012, pp. 25-36. Disponível em:

<https://www.sciencedirect.com/science/article/abs/pii/S0034425712000636\#!>. Acesso em: 07 fev. 2021.

DU, Yun et al. Water bodies' mapping from Sentinel-2 imagery with Modified Normalized Difference Water Index at 10-m spatial resolution produced by sharpening the swir band. Remote Sensing, v. 8, n. 4, 2016. Disponível em: <https://www.mdpi.com/2072-4292/8/4/354>. Acesso em: 13 fev. 2021.

DUARTE, Anderson Pires. Classificação das barragens de contenção de rejeitos de mineração e de resíduos industriais no estado de Minas Gerais em relação ao potencial de risco. 117 p. Dissertação (Mestrado) - Curso de Programa de PósGraduação em Saneamento, Meio Ambiente e Recursos Hídricos, Universidade Federal de Minas Gerais, Belo Horizonte, 2008. Disponível em: 
https://repositorio.ufmg.br/bitstream/1843/BUDB-

8AUPNJ/1/classifica_o_das_barragens_de_conten_o.pdf. Acesso em: $13 \mathrm{fev}$. 2021.

ESA - European Space Agency. Sentinels Scientific Data Hub, 2017. Disponível em: <https://sentinel.esa.int/web/sentinel/technical-guides/sentinel-2-msi/msiinstrument>. Acesso em: 13 de fev. 2021

ESPER ANGILLIERI, María Yanina; FERNÁNDEZ, Oscar Mario. Morphometric analysis of river basins using GIS and remote sensing of an Andean section of Route 150, Argentina. A comparison between manual and automated delineation of basins. Revista Mexicana de Ciencias Geológicas, vol. 34, núm. 2, 2017, pp. 150-156 Universidad Nacional Autónoma de México Querétaro, México. Disponível em: <https://www.redalyc.org/pdf/572/57253344007.pdf>. Acesso em: 13 fev. 2021.

FARR, Tom G. et al. The Shuttle Radar Topography Mission. Reviews of Geophysics, v. 45, n. 2, 19 maio 2007. Disponível em: $<$ https://agupubs.onlinelibrary.wiley.com/doi/full/10.1029/2005RG000183>. Acesso em: 13 fev. 2021.

FEYISA, Gudina L. et al. Automated Water Extraction Index: A new technique for surface water mapping using Landsat imagery. Remote Sensing of Environment, v. 140, January 2014, pp. 23-35. Disponível em:

$<$ https://www.sciencedirect.com/science/article/abs/pii/S0034425713002873>.

Acesso em: 07 fev. 2021.

G1. Barragem transborda no Nordeste da Bahia e autoridades divergem sobre rompimento. Jornal Nacional, 2019. Disponível em: <https://g1.globo.com/jornalnacional/noticia/2019/07/11/barragem-transborda-no-nordeste-da-bahia-eautoridades-divergem-sobre-rompimento.ghtml>. Acesso em: 13 fev. 2021.

GHEYI, H. R.; PAZ, V. P. S.; MEDEIROS, S. S.; GALVÃO, C. O. Recursos hídricos em regiões áridas e semiáridas. Campina Grande: Instituto Nacional do Semiárido, 2011. 258p.

HUANG, Chang. et al. Detecting, Extracting, and Monitoring Surface Water From Space Using Optical Sensors: A Review. Reviews of Geophysics, v. 56, n. 2, pp. 333-360, jun. 2018. Disponível em:

<https://agupubs.onlinelibrary.wiley.com/doi/pdfdirect/10.1029/2018RG000598>. Acesso em: 13 fev. 2021.

IBGE - INSTITUTO BRASILEIRO DE GEOGRAFIA E ESTATÍSTICA. Síntese de Indicadores Sociais: uma análise das condições de vida da população brasileira. Rio de Janeiro. IBGE, 2020. Disponível em:

https://biblioteca.ibge.gov.br/visualizacao/livros/liv101760.pdf. Acesso em: 13 fev. 2021.

IBGE - INSTITUTO BRASILEIRO DE GEOGRAFIA E ESTATÍSTICA. Censo agropecuário: resultados definitivos 2017. Rio de Janeiro. IBGE, 2019. Disponível em: <https://censos.ibge.gov.br/agro/2017/>. Acesso em: 13 fev. 2021. 
ICOLD. Dam failures: statistical analysis. Paris: ICOLD, 1995. (Bulletin, 99).

JACKSON, Christopher. Internal wave detection using the Moderate Resolution Imaging Spectroradiometer (MODIS). Journal of Geophysical Research: Oceans, v. 112, 2007. Disponível em:

<https://agupubs.onlinelibrary.wiley.com/doi/full/10.1029/2007JC004220>. Acesso em: 07 fev. 2021.

JI, Lei; ZHANG, Li; WYLIE, Bruce K. Analysis of dynamic thresholds for the normalized difference water index. Photogrammetric Engineering and Remote Sensing, v. 75, n. 11, 2009, pp. 1307-1317. Disponível em:

$<$ https://www.researchgate.net/publication/275681435_Analysis_of_Dynamic_Thresh olds_for_the_Normalized_Difference_Water_Index>. Acesso em: $0 \overline{7} \mathrm{fev} .202 \overline{1}$.

LEITE, Sérgio Ribeiro. Modelo para Avaliação de Riscos em Segurança de Barragens com Associação de Métodos de Análise de Decisão Multicritério e Conjuntos Fuzzy. 222 p. Dissertação - Mestrado Profissional em Computação Aplicada, Departamento de Ciência da Computação, Universidade de Brasília, Brasília, 2019. Disponível em:

<https://repositorio.unb.br/bitstream/10482/36965/1/2019_S\%C3\%A9rgioRibeiroLeite .pdf>. Acesso em: 07 fev. 2021.

FLORES, Yesica Ramirez et al. Estimativa de armazenamento de água em reservatórios através de sensoriamento remoto. 70 p. Dissertação (Mestrado) Programa de Pós-Graduação em Engenharia Agrícola, Universidade Federal de Santa Maria, Santa Maria 2019. Disponível em: <https://paimon.cpd.ufsm.br/bitstream/handle/1/17248/DIS_PPGEA_2019_FLORES _YESICA.pdf?sequence=1\&isAllowed=y>

MCFEETERS, S. K. The use of the Normalized Difference Water Index (NDWI) in the delineation of open water features. International Journal of Remote Sensing, $v$. 17, n. 7, p. 1425-1432, 1996.

MEDEIROS, Carlos Henrique de A. C. A regulamentação da Lei de Segurança de Barragens e seus Desafios: Relato de uma experiência. XXIX Seminário Nacional de Grandes Barragens, Pernambuco, 2013.

MENESCAL, Rogério de Abreu et al. Uma metodologia para avaliação do potencial de risco em barragens do semi-árido. Seminário nacional de grandes barragens, 2001.

MOLLE, François. Geometria de Pequenos Açudes. Recife: Sudene, 1994.

NAVA, Francy Rosy et al. Pequenas barragens: uma oportunidade de desenvolvimento científico, técnico e regulamentador. 189 p. Dissertação (Mestrado) - Programa de Pós-Graduação em Engenharia de Barragem e Gestão Ambiental, Campus Universitário de Tucuruí, Universidade Federal do Pará, Tucuruí, 2018. Disponível em:

<http://pebga.propesp.ufpa.br/ARQUIVOS/dissertacoes/Disserta\%C3\%A7\%C3\%A3o \%20Final\%20PEBGA\%20Francy\%20Rosy\%20Nava.pdf>. Acesso em: 13 fev. 2021. 
NEVES, Luiz Paniago. Segurança de Barragens: Legislação Federal Brasileira em Segurança de Barragens Comentada. Brasília, 2018. Disponível em:

$<$ https://www.gov.br/anm/pt-br/assuntos/barragens/e-book-livre-legislacao-federalbrasileira-em-seguranca-de-barragens-autor-luiz-paniago-neves>. Acesso em: 07 fev. 2021.

NGOC, Dat Dinh. et al. Coastal and inland water pixels extraction algorithm (WiPE) from spectral shape analysis and HSV transformation applied to Landsat $8 \mathrm{OLI}$ and Sentinel-2 MSI. Remote Sensing of Environment, v. 223, 15 March 2019, pp. 208228. Disponível em:

<https://www.sciencedirect.com/science/article/abs/pii/S0034425719300276>. Acesso em: 07 fev. 2021.

PARAÍBA. Decreto n 19.258, de 31 de outubro de 1997 - Controle Técnico de Obras e Serviços de Oferta Hídrica. Regulamenta o controle técnico das obras e serviços de oferta hídrica e dá outras providências. Disponível em: $<$ http://www.aesa.pb.gov.br/aesa-website/wpcontent/uploads/2016/11/DECRETO_15.pdf>. Acesso em: 07 fev. 2021.

PARAÍBA. Decreto $n^{\circ}$ 39.014, de 26 de fevereiro de 2019. Dispõe sobre o cadastramento de obras hídricas construídas e pendentes de regularização até o advento do presente Decreto, para fins de concessão de licenciamento e dá outras providências. Disponível em: <http://www.aesa.pb.gov.br/aesa-website/wpcontent/uploads/2019/04/Decreto-N\%C2\%BA-39.014-de-26-de-fevereiro-de2019.pdf>. Acesso em: 07 fev. 2021.

PARAÍBA. Lei n $^{\circ}$ 6.308, de 02 de julho de 1996. Institui a Política Estadual de Recursos Hídricos, suas diretrizes e dá outras providências. Disponível em: < http://progestao.ana.gov.br/portal/progestao/panorama-dos-estados/pb/lei-no-6-30896_pb.pdf/@@download/file/LEI\%20N\%C2\%BA\%206.308-96_PB.pdf>. Acesso em: 07 fev. 2021.

PARAÍBA. Meteorologia - Chuvas: precipitação máxima dos municípios/postos no ano 2021. Agência Executiva de Gestão de Águas - AESA. Disponível em: $<$ http://www.aesa.pb.gov.br/aesa-website/meteorologia-chuvas/?formdate=2021-0213\&produto=municipio\&periodo=anual>. Acesso em: 13 fev. 2021.

PARAÍBA. Resolução $n^{\circ}$ 3, de 11 de fevereiro 2016. Define a periodicidade, a qualificação da equipe responsável, o conteúdo mínimo e nível de detalhamento das inspeções de segurança regular e especial de Barragem. Disponível em: $<$ http://www.aesa.pb.gov.br/aesa-website/wpcontent/uploads/2017/08/Resolu\%C3\%A7\%C3\%A3o-N\%C2\%BA-03-de-11-defevereiro-de-2016.pdf>. Acesso em: 07 fev. 2021.

PARAÍBA. Resolução $n^{\circ}$ 4, de 25 de novembro de 2016. Estabelece a periodicidade de atualização, a qualificação do responsável técnico, o conteúdo mínimo e o nível de detalhamento do Plano de Segurança da Barragem e da Revisão Periódica de Segurança da Barragem, conforme art. $8^{\circ}, 10$ e 19 da Lei $n^{\circ}$ 12.334 de 20 de setembro de 2010 - a Política Nacional de Segurança de Barragens 
- PNSB. Disponível em: <http://www.aesa.pb.gov.br/aesa-website/wpcontent/uploads/2018/02/Resolu\%C3\%A7\%C3\%A3o-n\%C2\%BA-4-de-25-deNovembro-de-2016-AESA.pdf>. Acesso em: 07 fev. 2021.

PEKEL, Jean-François. et al. High-resolution mapping of global surface water and its long-term changes. Nature, v. 540, n. 7633, pp. 418-422, 2016. Disponível em: <https://www.nature.com/articles/nature20584>. Acesso em: 13 fev. 2021.

PERSECHINI, Maria Inês Muanis et al. Segurança de barragens: engenharia a serviço da sociedade. Brasília - DF: 2015.

PINTO, Willian Leandro Henrique. Índice de Segurança de Pequenas Barragens (ISPB) como método para a avaliação da segurança de pequenas barragens de água. 188 p. Dissertação (Mestrado) - Universidade Estadual de Campinas, Faculdade de Tecnologia, Limeira, SP, 2020. Disponível em: <http://repositorio.unicamp.br/handle/REPOSIP/349302>. Acesso em: 07 fev. 2021.

PIMENTA, M. L. B. Abordagens de riscos em barragens de aterro. 570 p. Tese (Doutorado) - Curso de Engenharia Civil, Laboratório Nacional de Engenharia Civil, Universidade Técnica de Lisboa, Lisboa, 2009. Disponível em:

<http://repositorio.Inec.pt:8080/jspui/handle/123456789/17187>. Acesso em: 07 fev. 2021.

PISANIELLO, J. D. How to manage the cumulative flood safety of catchment dams. Water SA, v. 35, n. 4, 2009. Disponível em:

<https://www.ajol.info/index.php/wsa/article/view/76783>. Acesso em: 07 fev. 2021.

SANTOS, F.A. dos; SILANS, A.M.B.P. de; PORTO, R. de Q.; ALMEIDA, C. das N. Estimativa e análise do volume dos pequenos açudes através de imagem de satélite e levantamento de campo na bacia hidrográfica do açude Sumé. In: XVIII Simpósio Brasileiro de Recursos Hídricos, 22 a 26 de novembro de 2009, Campo Grande MS.

SAWUNYAMA, Tendai; SENZANJE, Aidan; MHIZHA, Alexander. Estimation of small reservoir storage capacities in Limpopo River Basin using geographical information systems (GIS) and remotely sensed surface areas: Case of Mzingwane catchment. Physics and Chemistry of the Earth, v. 31, n. 15/16, pp. 935-943, 2006. Disponível em: <https://www.sciencedirect.com/science/article/pii/S1474706506001677>. Acesso em: 13 fev. 2021.

SEKERTEKIN, Aliihsan; CICEKLI, Sevim Yasemin; ARSLAN, Niyazi. Index-Based Identification of Surface Water Resources Using Sentinel-2 Satellite Imagery. ISMSIT 2018 - 2nd International Symposium on Multidisciplinary Studies and Innovative Technologies, Proceedings, pp. 1-5, 2018. Disponível em: <https://ieeexplore.ieee.org/document/8567062>. Acesso em: 13 fev. 2021.

SIQUEIRA, Vinícius Alencar et al. IPH-Hydro Tools: a GIS coupled tool for watershed topology acquisition in an open-source environment. Revista Brasileira de

Recursos Hídricos, v. 21, n. 1, p. 274-287, 25 fev. 2016. Disponível em: 
<https://www.scielo.br/scielo.php?pid=S2318-

03312016000100274\&script=sci_arttext\&tlng=en>. Acesso em: 13 fev. 2021.

SMITH, Alvy Ray. Color gamut transform pairs. ACM SIGGRAPH Computer Graphics, v. 12, n. 3, p. 12-19, 23 ago. 1978. Disponível em:

$<$ https://www.researchgate.net/publication/233784968_Color_Gamut_Transform_Pai rs>. Acesso em: 13 fev. 2021.

SWAN, Benjamin; GRIFFIN, Robert. A LiDAR-optical data fusion approach for identifying and measuring small stream impoundments and dams. Transactions in GIS, v. 24, n. 1, pp. 174-188, 2020. Disponível em:

<https://onlinelibrary.wiley.com/doi/abs/10.1111/tgis.12595>. Acesso em: 07 fev. 2021.

VISEU, Maria Teresa Fontelas. Segurança dos vales a jusante de barragens: metodologias de apoio à gestão de risco. 377 p. Tese (Doutorado) - Curso de Engenharia Civil, Laboratório Nacional de Engenharia Civil, Universidade Técnica de Lisboa, Lisboa, 2008. Disponível em:

<http://repositorio.Inec.pt:8080/jspui/handle/123456789/15575>. Acesso em: 07 fev. 2021.

WANG, Zifeng et al. Multi-SpectralWater Index (MuWI): A Native 10-m MultiSpectralWater Index for accuratewater mapping on sentinel-2. Remote Sensing, v. 10, n. 10, pp. 1-21, 2018. Disponível em: <https://www.mdpi.com/20724292/10/10/1643>. Acesso em: 07 fev. 2021.

XIAOLE, Shen et al. An uneven illumination correction algorithm for optical remote sensing images covered with thin clouds. Remote Sensing, v. 7, n. 9, 2015.

Disponível em: <https://www.mdpi.com/2072-4292/7/9/11848>. Acesso em: 07 fev. 2021.

XIE, H. et al. Automated Subpixel Surface Water Mapping from Heterogeneous Urban Environments Using Landsat 8 OLI Imagery. Remote Sensing, v. 8, n. 7, p. 584, 12 jul. 2016. Disponível em: <https://www.mdpi.com/2072-4292/8/7/584>. Acesso em: 13 fev. 2021.

XU, Hanqiu. Modification of normalised difference water index (NDWI) to enhance open water features in remotely sensed imagery. International Journal of Remote Sensing, v. 27, n. 14, pp. 3025-3033, 20 jul. 2006. Disponível em: <https://www.tandfonline.com/doi/abs/10.1080/01431160600589179>. Acesso em: 13 fev. 2021.

YANG, Xiucheng et al. Mapping of urban surface water bodies from sentinel-2 MSI imagery at $10 \mathrm{~m}$ resolution via NDWI-based image sharpening. Remote Sensing, v. 9, n. 6, pp. 1-19, 2017. Disponível em: <https://www.mdpi.com/2072-4292/9/6/596>. Acesso em: 13 fev. 2021.

ZHANG, Wensong et al. Identifying emerging reservoirs along regulated rivers using multi-source remote sensing observations. Remote Sensing, v. 11, n. 1, 2019. 
Disponível em: <https://www.mdpi.com/2072-4292/11/1/25 >. Acesso em: 13 fev. 2021.

ZOU, Zhenhua et al. Divergent trends of open-surface water body area in the contiguous United States from 1984 to 2016. Proceedings of the National Academy of Sciences, v. 115, n. 15, pp. 3810-3815, 10 abr. 2018. Disponível em: <https://pubmed.ncbi.nlm.nih.gov/29581291/>. Acesso em: 13 fev. 2021.

ZUFFO, Monica Soares Resio. Metodologia para avaliação de segurança de barragens. 192p. Dissertação (Mestrado) - Universidade Estadual de Campinas, Faculdade de Engenharia Civil, Arquitetura e Urbanismo. 2005.

ZUFFO, Monica Soares Resio. Análise de Risco em Barragens: um índice de priorização. 291p. Tese (Doutorado) - Universidade Estadual de Campinas, Faculdade de Engenharia Civil, Arquitetura e Urbanismo. 2010. 


\section{APÊNDICE A - Tutorial para identificação e extração das massas de água através do aplicativo Google Earth Engine}

Como apresentado na pesquisa a identificação dos cursos d'água através do Google Earth Engine é automática, realizada através do script apresentado a seguir. Com o uso do script é possível realizar esse processo para qualquer área de interesse como a bacia hidrográfica, o município ou até mesmo um estado inteiro, pois todo processamento é feito na nuvem. Os inputs necessários são os dados do Sentinel-2 e a área de interesse.

\section{Input dos dados de satélite e área de interesse.}

\subsection{Dados Sentinel-2}

Os dados do satélite podem ser obtidos no campo de buscas do GEE (Figura 1).

Figura 1 - Campo de Buscas do GEE

\begin{tabular}{|c|c|}
\hline Sentinel-2 MSI| & Q \\
\hline \\
\hline \multicolumn{2}{|l|}{ RASTERS } \\
\hline \multicolumn{2}{|l|}{ Sentinel-2 MSI: MultiSpectral Instrument, Level-1C } \\
\hline \multicolumn{2}{|l|}{ Sentinel-2 MSI: MultiSpectral Instrument, Level-2A } \\
\hline sentinel-z: Cloud Prodadility & \\
\hline & \\
\hline
\end{tabular}

\subsection{Inserir área de interesse.}

Pode-se adicionar como área de interesse um extensão delimitada no próprio GEE ou pode-se inserir shapefiles da área de interesse. Para inserir os arquivos tipo shapefile, basta clicar na aba Assets e depois no botão NEW como ilustrado na Figura 2 e selecionar a opção shapefile, é importante que os arquivos estejam no formato .zip para que não ocorra erro no processo de importação. 
Figura 2 - Input da área de interesse.

\begin{tabular}{l} 
Scripts Docs Assets \\
Image Upload \\
GeoTIFF (.tif, .tiff) or TFRecord (.tfrecord +.json) \\
Table Upload \\
Shape files (.shp, .shx, .dbf, .prj, or .zip) \\
csV file (.csv) \\
Image collection \\
Folder \\
\hline$-\ldots$ - ...-1
\end{tabular}

Então será aberta a janela para upload (Figura 3), clique em SELECT e selecione o arquivo desejado e clique em UPLOAD.

Figura 3 - Janela de upload.

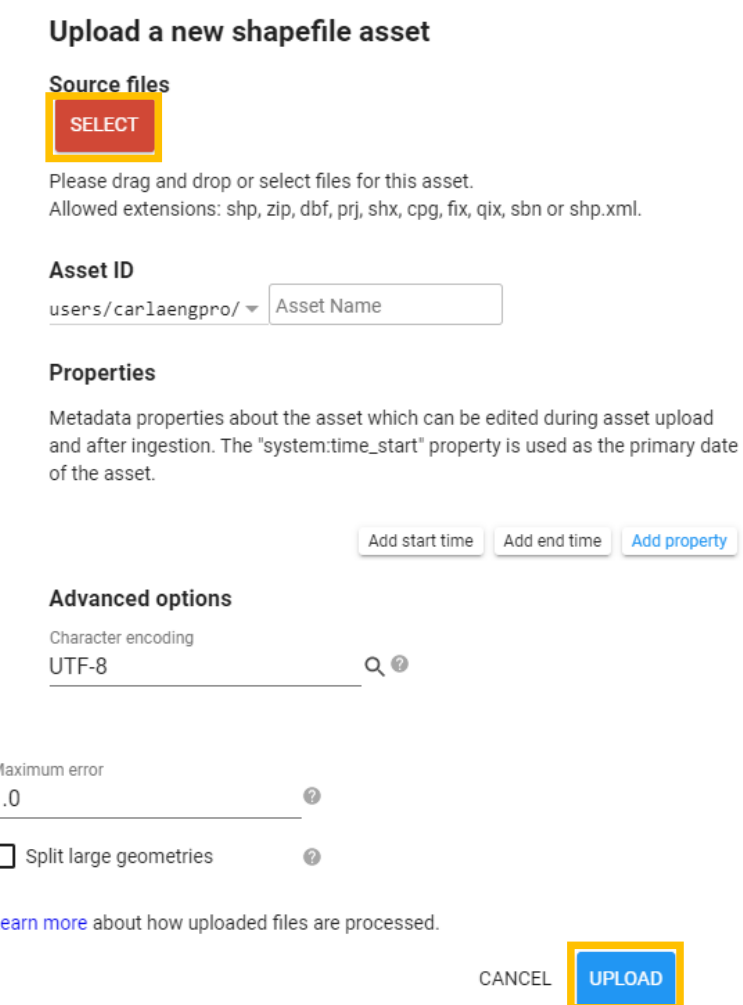


Ao iniciar o processo a aba Tasks (Figura 4) pisca uma cor laranja indicando o início do upload. A demora aqui é relativa ao tamanho do arquivo da área de interesse.

Figura 4 - Início do upload.

\section{Inspector Console Tasks}

$\underline{1}$ Starting to ingest asset. ? 5 s

Após a conclusão do upload o arquivo aparece a lista de Assets (Figura 55), e para inserir os dados no script basta apenas clicar na seta em azul.

Figura 5 - Lista de arquivos inseridos no GEE.

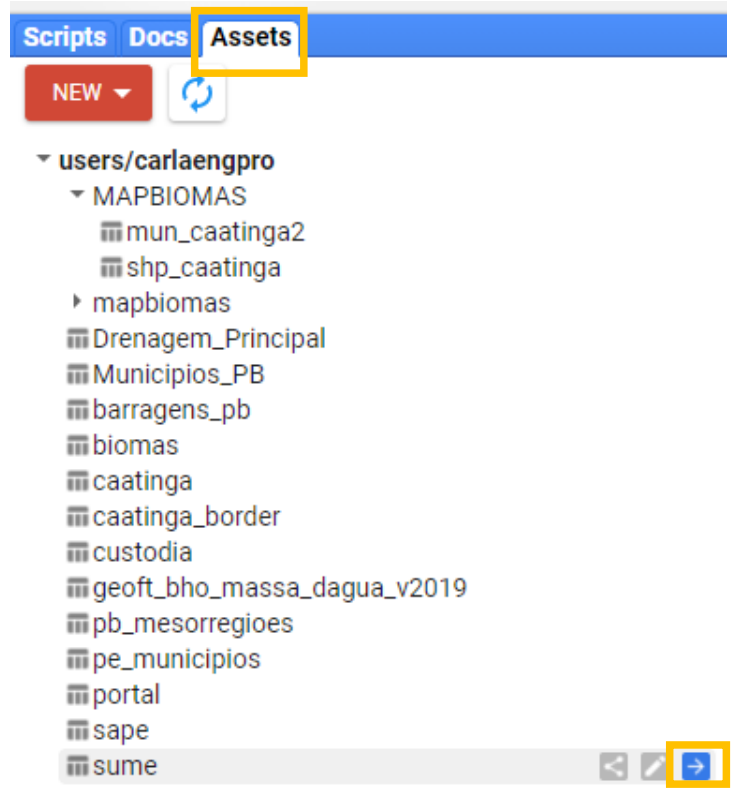

\section{Alterações no script}

A área de interesse entra como uma variável no script, uma informação importante é o id do seu arquivo (Figura 6), pois será usado para identificar a variável dentro do script.

Figura 6 - Informações sobre a variável inserida.

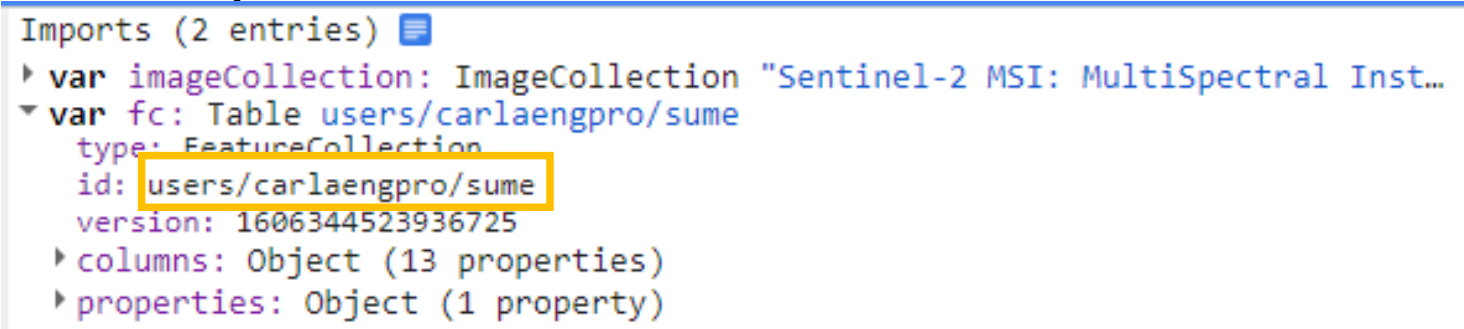


Após a inserção dos dados de satélite e da área de interesse, segue-se para descrição do script. Para um melhor entendimento o script foi divido em blocos.

I - Bloco 1: Apresenta as funções iniciais de pré processamento da imagem, aplica-se nessa etapa filtros e máscaras para nuvens.

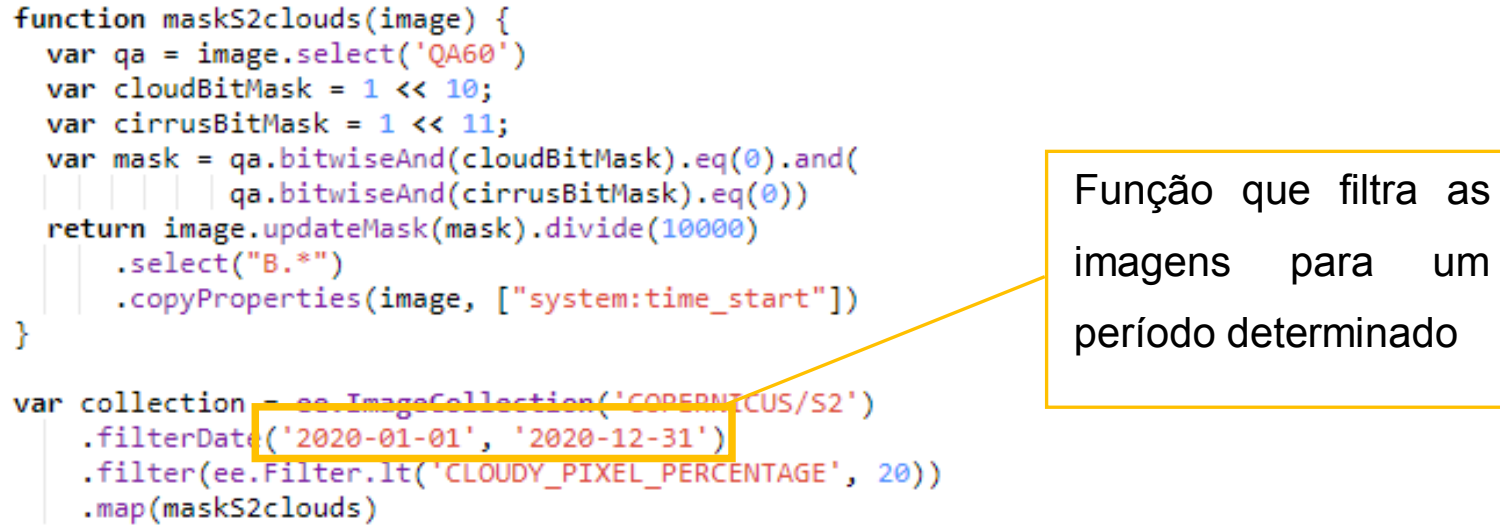

Função que filtra as
imagens para um
período determinado

Função que filtra as período determinado

II - Bloco 2: Recorte da coleção pela camada da área de interesse.

\section{II- Bloco 2: Recorte da coleção pela camada da área de interesse.}

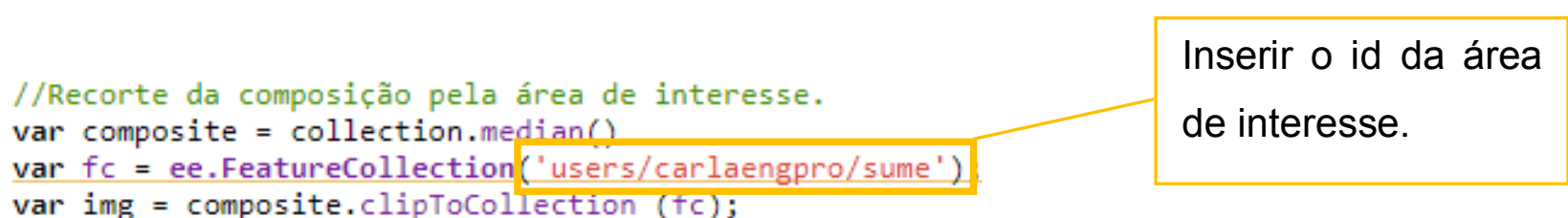

III - Bloco 3: Cálculo dos índices NDWI, NDWIm e Transformação HSV.

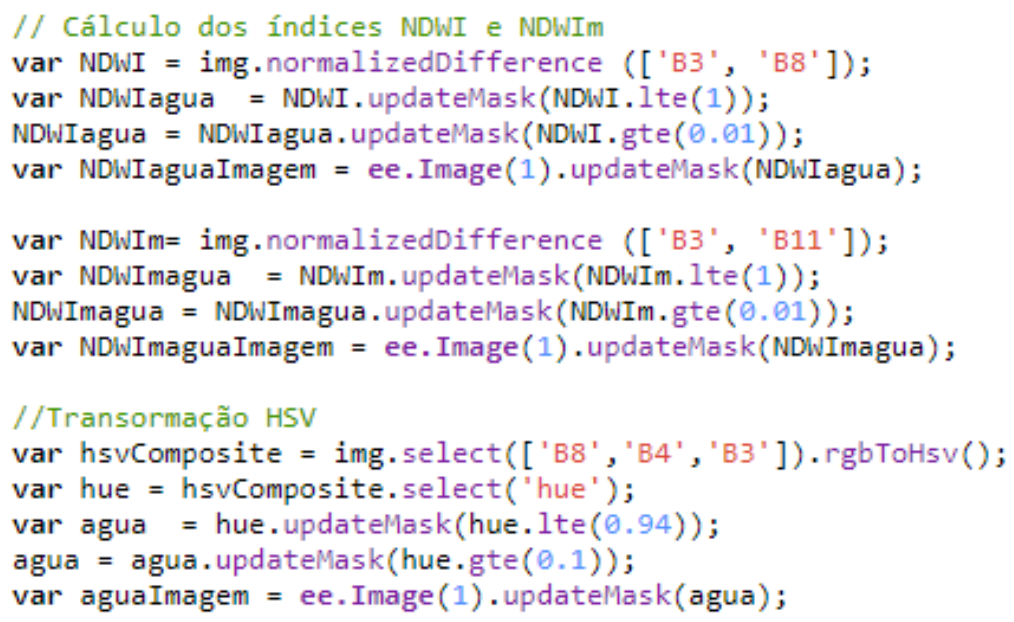


A Figura 2 ilustra dos produtos gerados no processo e exportados para posterior utilização em sistemas SIG. Os arquivos são do tipo raster.

Figura 2 - Ilustração dos produtos gerados e exportados.

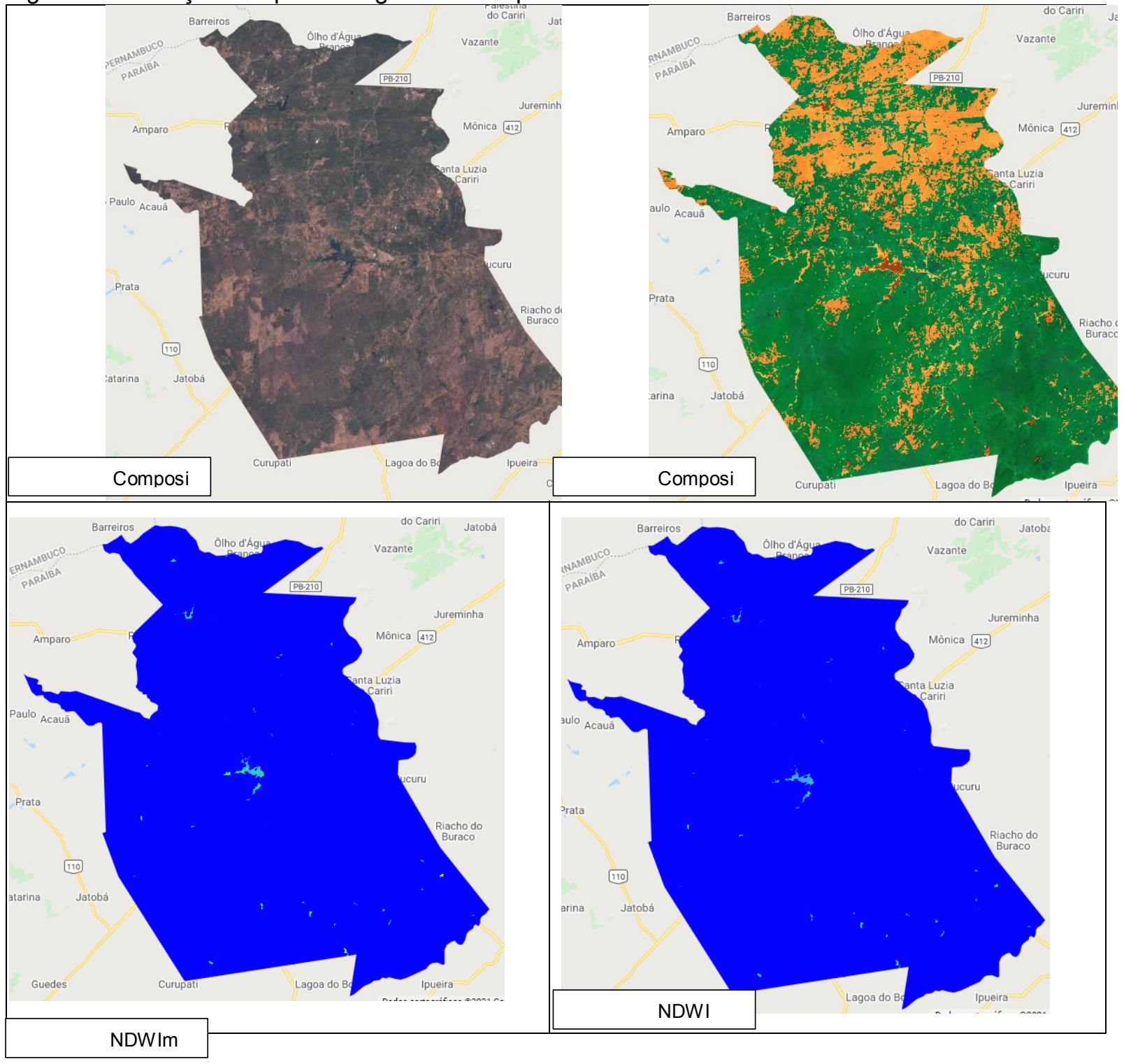

Para ter acesso ao o script clique no link abaixo:

https://code.earthengine.google.com/?scriptPath=users $\% 2 F$ carlaengpro\%2Fsrtm\%3 AidentificacaoAgua. 
APÊNDICE B - Mapa com a identificação e localização das barragens do município de Sumé.

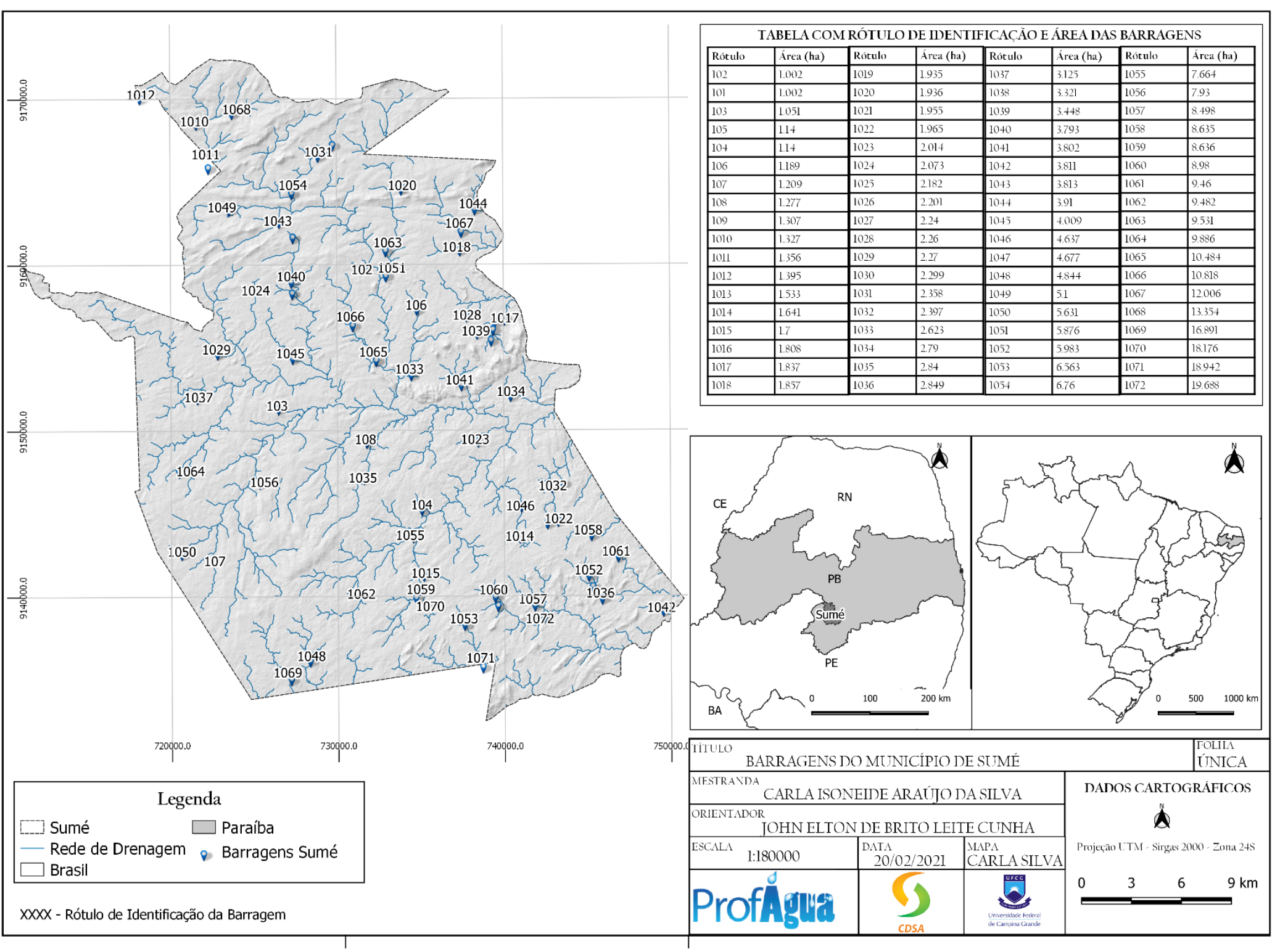

